LAURA AYAKO YAMANE

\title{
ESTAMPARIA TÊXTIL
}

São Paulo

2008 


\section{ESTAMPARIA TÊXTIL}

Dissertação de Mestrado apresentada ao Programa de Pós-Graduação da Escola de Comunicações e Artes da Universidade de São Paulo, Área de Concentração: Artes Visuais, na Linha de Pesquisa: Poéticas Visuais para obtenção do título de Mestre em Artes, sob orientação do Prof. Dr. Donato Ferrari.

São Paulo 
FOLHA DE APROVAÇÃO

Prof. Dr. (a)

Prof. Dr. (a)

Prof. Dr. (a) 


\section{DEDICATÓRIA}

Dedico esta dissertação a meu pai Shiguetaro Yamane (in memorian), minha mãe María Yamane, meusirmãos Kíyoko Yamane Takizawa, Mitiko Yamane Barros, Toshio Yamane, Augusto Shigueharw Yamane. 


\section{AGRADECIMENTOS}

Ao Prof.Dr. DONATO FERRARI, pela atenção e apoio durante o processo de definição e orientação deste trabalho.

À ANA MARIA da Biblioteca do Senai Têxtil.

À ELLEN M. LEITE, coordenadora de moda da ABIT. Ao SYLVIO DI NAPOLI da ABIT.

Ao SR. JOSÉ MACEDO, diretor da Sintequímica.

Ao ENG. GUSTAVO, da Vicunha Têxtil.

À Da. MIRIAN E GINA GOLDENBERG, da Estamparia Eregue, pela valiosa ajuda ao imprimir a capa de minha dissertação.

Ao JORGE NAGAI, da Fotoestampa C \& N, por confeccionar os quadros para imprimir.

À CECILIA OH, da Luan.

À ANA MILLIET, do Studio de Estamparia.

Ao NAKA, da Estamparia Pari.

Ao VILSON, da Estamparia Prisma.

Ao RONALDO STILLO, da Fotoestampa Futura.

Aos funcionários da Biblioteca do Senai Cetiqt - Rio de Janeiro. Ao Prof. Dr. ROBERT HIRSCHLER, do Senai Cetiqt - Rio de Janeiro. À ELAINE, da Multiofício - que formatou e revisou, com tanto carinho, a minha dissertação.

Aos funcionários da Biblioteca da ECA.

À REGINA, da Secretaria de Pós-Graduação da ECA.

E a todos os funcionários da Secretaria de Pós-graduação da ECA.

Ao Comitê da Feira Tissu Premier Lille-Paris. 
"Eu criei um estilo para um mundo inteiro. Vê-se em todas as lojas "estilo Chanel". Não há nada que se assemelhe.

Sou escrava do meu estilo.

Um estilo não sai da moda;

Chanel não sai da moda." 


\section{RESUMO}

As manifestações culturais e artísticas surgiram no setor têxtil ainda nos primórdios da humanidade, utilizando-se, desde então, de pigmentos vegetais, e criando uma verdadeira aliança entre o ser humano, a natureza e o mundo do desenho. A moda retrata aspectos do vestuário desde o início da história do homem até a atualidade, relatando a estreita ligação com as tendências globalizadas. A moda, enquanto conseqüência do mundo econômico, reflete os acontecimentos sociais, culturais, políticos, econômicos e ambientais. O presente estudo visa a introduzir os conceitos estruturais a respeito da cor, desde a sua definição até a ilustração dos ícones aos quais está associada. Introduz ainda a estamparia, que é das mais exigentes técnicas têxteis, e também a que mais se aproxima da Arte, indicando sua origem, fontes de inspiração, os diversos processos de fabricação e sua aplicação, desde os processos manuais até os digitais. Esta pesquisa versa sobre a importante e estratégica etapa de Pesquisa de Tendências, através de várias fontes, principalmente a Internet, a seleção de produtos junto aos vários profissionais, e, finalmente, o desenvolvimento de produtos têxteis nas fábricas, a necessidade de utilização de todo o maquinário disponível na tecelagem, na tinturaria e na estamparia.

Palavras-chave: Moda, desenvolvimento de projeto têxtil, Estamparia, cores. 


\begin{abstract}
Cultural and artistic demonstrations started in the textile sector at the very beginning of humankind, creating a alliance between the human being, nature and the world of design. They outline fashion and have displayed features of clothing since the early ages, telling the strong connection with world trends. Fashion is a reflexion of social, political, economical (and currently environmental) events, as a consequence of the economic world. The present research aims to introduce the structural concepts of color, from its definition to the illustration of the icons to which it is associated. It also introduces prints, which is one of the most demanding textile techniques, and is also the closest to art, demonstrating sources of inspiration, several manufacturing processes and applications, from manual to technological processes. It shows the import and strategic stage of trends research, from several sources, mainly by internet; the selection of products along several professionals and, finally the development of textile products in the factories a requirement of the use of all available machinery weaving as well as coloring and printing.
\end{abstract}

Keywords: Fashion, textile development, prints, colour. 


\section{SUMÁRIO}

1 INTRODUÇÃO 9

2 DEFINIÇÃO DE ESTAMPARIA 11

2.1 Histórico 11

$\begin{array}{lll}2.2 \text { Definição e Função } & 18\end{array}$

2.3 Sequências cronológicas 22

2.3.1 Cores - Intercolor 24

2.3.2 Fios Pitti Filatti (Firenzi), Expofil (Paris) 25

2.3.3 Feiras de Tecidos 25

2.3.4 Feira do Vestuário 26

2.3.5 Semana de Desfiles $\quad 27$

2.3.6 Vitrinas nas principais e importantes lojas 27

2.3.7 Outras fontes de informação importantes 28

2.4 Como tem início o projeto de uma Coleção 30

3 ESTAMPARIA - FUNDAMENTOS TEÓRICOS 36

3.1 Histórico da Cor 36

3.1.1 O processo fisiológico: o olho 54

3.2 Formas 55

3.3 Harmonia e Equilíbrio 56

3.3.1 Harmonia cromática 56

3.3.2 Harmonia monocromática 57

3.3.3 Harmonia Análoga 58

3.3.4 Harmonia Complementar ou Oposta 59

3.3.5 Harmonia Complementar ou Dividida 59

3.3.6 Harmonia Complementar ou Duplamente Dividida 60

3.3.7 Harmonias Triplas ou Tríade 60

3.3.8 Harmonia e Equilíbrio 64 
4 O DESENHO E A CRIAÇÃO DA PADRONAGEM 67

$\begin{array}{lll}4.1 & \text { Manual } & 67\end{array}$

$\begin{array}{lll}4.2 & \text { Digital } & 70\end{array}$

4.2.1 O processo de criação digital 72

4.2.2 Análise: Desenho de Estamparia Manual X Digital 74

$\begin{array}{lll}4.3 & \text { Rapport } & 75\end{array}$

4.4 Relação Arte e Estamparia 80

4.4.1 Willian Morris e a relação Arte e Indústria 81

4.4.2 Bauhaus e o Design Contemporâneo 82

4.4.3 Relação Arte e Moda 88

5 PROCESSOS DE ESTAMPARIA 102

$\begin{array}{lll}5.1 & \text { Manual } & 102\end{array}$

$\begin{array}{lll}5.2 & 102\end{array}$

5.2.1 Cilindro e Quadros 102

$\begin{array}{lll}\text { 5.2.2 Estamparia Transfer-Paper } & 106\end{array}$

$\begin{array}{lll}5.2 .3 & 108\end{array}$

5.2.4 Processos de Gravação 112

6 CONCLUSÃO 116

$\begin{array}{ll}\text { BIBLIOGRAFIA } & 117\end{array}$

ANEXOS 


\section{INTRODUÇÃO}

A realização do presente estudo partiu do questionamento da relação casual entre a escassez de registros no que abrange ao estudo das cores na estamparia e na necessidade de um estudo sistematizado aprofundando a influência notória que certas questões relacionadas provocam na alteração das tendências de moda, que são globais.

Através de levantamento bibliográfico, pesquisa de campo, entrevistas, entre outros, referentes à escolha e mudança das cores, o trabalho visa a documentar a importância da cor dentro do universo têxtil, destacando a estamparia e mostrando a relevância que a mesma possui na escolha de novas propensões. Juntamente com renomados autores, busca desenvolver uma linha aprofundada de acordo com a história, teorias, processos e conceitos de cada um acerca dos assuntos abordados.

Desta forma, pretende proporcionar de forma linear um resgate histórico e uma ressignificação estética, apresentando condições para uma visão consciente de todo o processo de escolha e reconhecimento dos padrões clássicos para cada um dos países. E ainda, disponibilizar mais uma fonte de estudo a futuros pesquisadores, rica em informações vivenciadas e trabalhadas durante anos de dedicação a área.

$\mathrm{Na}$ concretização do projeto pode-se colocar referências primeiramente pela formação em desenho industrial, atuar como estilista há vários anos e vivenciar estágios em diversos pontos do mundo em moda, criando tecidos, malharia e padronagem em estamparias para grandes e renomadas empresas nacionais e internacionais mantendo-se, portanto, em íntimo contato com desfiles, atualizando constantemente através das novas coleções, estilistas emergentes (brasileiros e estrangeiros) e designers responsáveis pelas cores solicitadas.

Por fim, ressaltamos que possuímos fácil acesso a inúmeras fontes e que estamos munidos de subsídios para aprofundar e aumentar os conhecimentos a respeito desta área tão abrangente e de uso da maioria dos seres humanos, presente no diaa-dia das culturas. Recolhendo e sistematizando informações, colocando toda a 
prática adquirida nestes anos à disposição, buscamos proporcionar um estudo científico que sirva às atuais e futuras gerações de profissionais do ramo têxtil e da psicologia das cores aplicada ao vestuário cotidiano das pessoas. 


\section{DEFINIÇÃO DE ESTAMPARIA}

\subsection{Histórico}

Segundo a apostila do Laboratório Sandoz S.A $A^{1}$ a necessidade do homem em viver em um meio ambiente alegre e colorido faz parte de sua natureza.

As primeiras estampas surgiram antes da era cristã e foram feitas na Índia e Indonésia. Os egípcios criaram as estampas no período "Eoptic" nos séculos V e VI a.C.
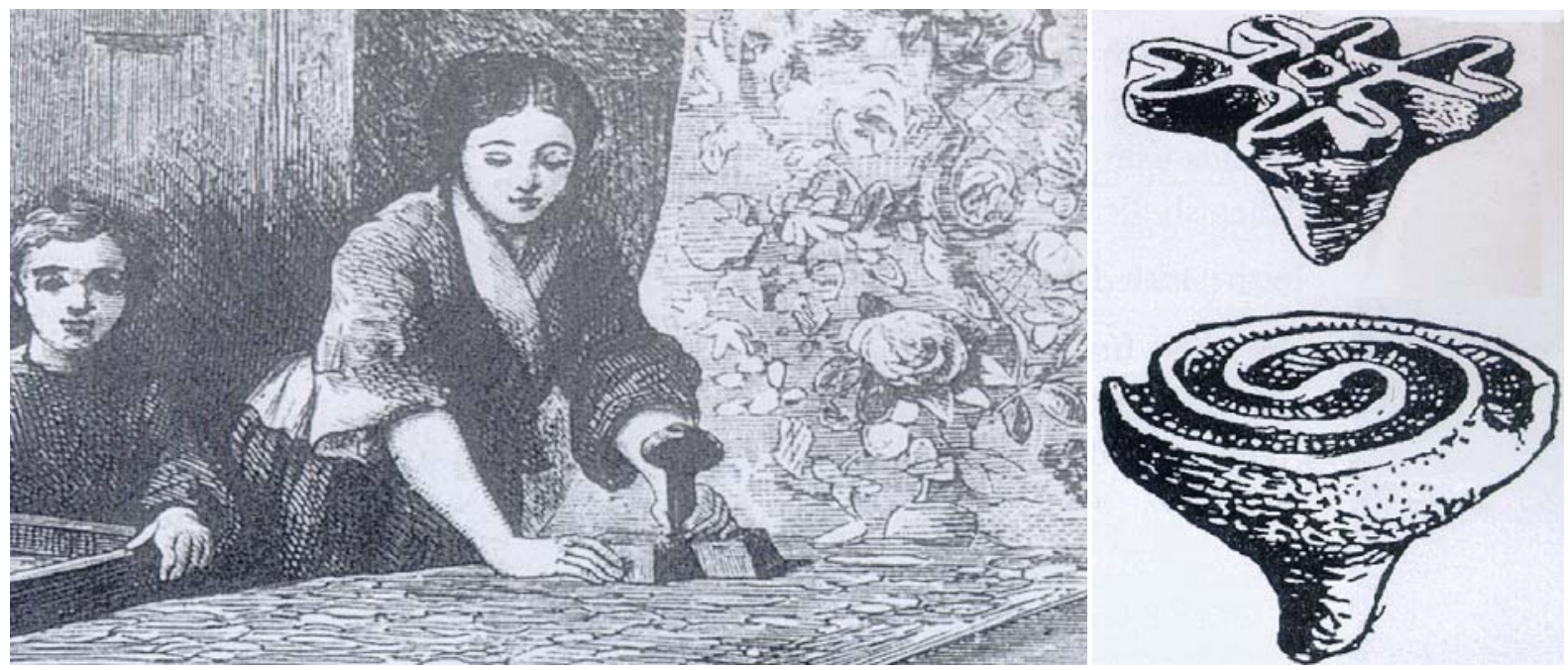

Tratava-se de uma combinação de reservas de pintura e estampagem com modelos, que eram blocos de madeira com motivos gravados, muito apreciados. Estampar é uma das mais exigentes técnicas têxteis, e também a que mais se aproxima da arte.

Os fenícios produziram os primeiros tecidos estampados, usando o método de estamparia em blocos e a tecelagem trabalhada em fios de diversas cores formando estampas muito apreciadas pelo mercado. Outro método usado era o stencil, em diferentes estamparias, além de bordados em cores ricas e vibrantes. 
A Índia era mestra na arte da estamparia, sendo que seus produtos superavam, em muito, o trabalho feito pelos persas e egípcios. Porém, existem exemplos de estamparia utilizando blocos de madeira sobre linho durante a Idade Média, técnica muito provavelmente trazida da Ásia e introduzida pelos romanos na Europa.

Estampas usando a técnica de serigrafia sobre linho foram escavadas pelos arqueólogos em tumbas egípcias de 8.000 anos. Seda estampada foi encontrada em escavações a leste do Turkistão e Kansu, possivelmente originárias da dinastia Tang chinesa.

Uma obra da época inicial da estamparia é o tapete de Sitten, executado na primeira metade do século XIV, e que hoje está exposto no Museu da História, na Basiléia, Suíça. Para sua estampagem foram utilizados 15 modelos diferentes somente nas cores preto e vermelho, em fundo branco. (APOSTILA CLARIANT) ${ }^{2}$.

A arte de impressão sobre os têxteis apareceu no sudoeste da Ásia no início do século XVI, havia um tecido rústico chamado Icaten, que derivou para Caten e depois Cotton (algodão). Este recebia aplicações de cera, impedindo a absorção da tinta ou corante, ficando reservado ou branco, técnica artesanal chamada de Batik. Existe o batik africano e o javanês No batik javanês, o efeito final é produzido por sucessivos tingimentos no tecido, protegido por máscaras de cera, onde somente as partes não vedadas pela cera são tingidas. As máscaras são aplicadas sobre a seda com pincel.

Outro detalhe interessante diz respeito ao vestuário do homem durante a Idade Média, que era de uma cor só: azul, marrom ou preto, os multicoloridos eram privilégio somente dos nobres. (APOSTILA CLARIANT) ${ }^{3}$

\section{Europa}

$\mathrm{Na}$ Europa, as mais velhas estampas datam do ano 543. Foi partir do ano 1000, quando Veneza estabeleceu sua posição como porto de difusão de mercadorias entre o Leste e o Oeste que os tecidos estampados começaram a ganhar força na moda européia. De todas as transações comerciais importantes, Veneza dava 
prioridade à importação de seda e tecidos preciosos, assim como especiarias e gemas do Oriente (MANCHESTER, 1996; ARAÚJO, CASTRO, 1999).

Para os espanhóis dos séculos XIV e XV a seda era muito cobiçada, pois refletia uma distinção soberba, que os atraia devido ao seu temperamento.

Por volta do ano 1200 d.C. aconteceram várias mudanças importantes, entre elas o fato de as cores deixarem de possuir um significado simbólico, não mais sendo usadas com o propósito específico de indicar as diferenças de classes - papel este que passou a ser exercido pelo tecido, no caso a seda, devido ao seu alto valor de mercado.

Diferente da seda, os tecidos comuns eram de cores sólidas. As roupas comuns e de cerimônia eram decoradas com bordados e appliqués formando devices: imagens de objetos, plantas ou animais escolhidos para representar emblemas pessoais, como o urso e o cisne sangrento do Duque de Berry ${ }^{4}$.

Apesar do trabalho dos centros têxteis europeus, os tecidos orientais continuavam a exercer forte atração sobre os países ocidentais: musselina de seda e ouro de Mossul; tecidos adamascados, isto é, com padronagem de Damasco e Pérsia; sedas baldacchino decoradas com pequenas figuras; sendo estas encontradas até na Inglaterra; tecidos da Antioquia, com pequenos pássaros dourados ou azuis sobre campos vermelhos ou pretos. Os tecidos orientais eram muito apreciados por causa de suas padronagens e, principalmente, devido a sua perfeição técnica.
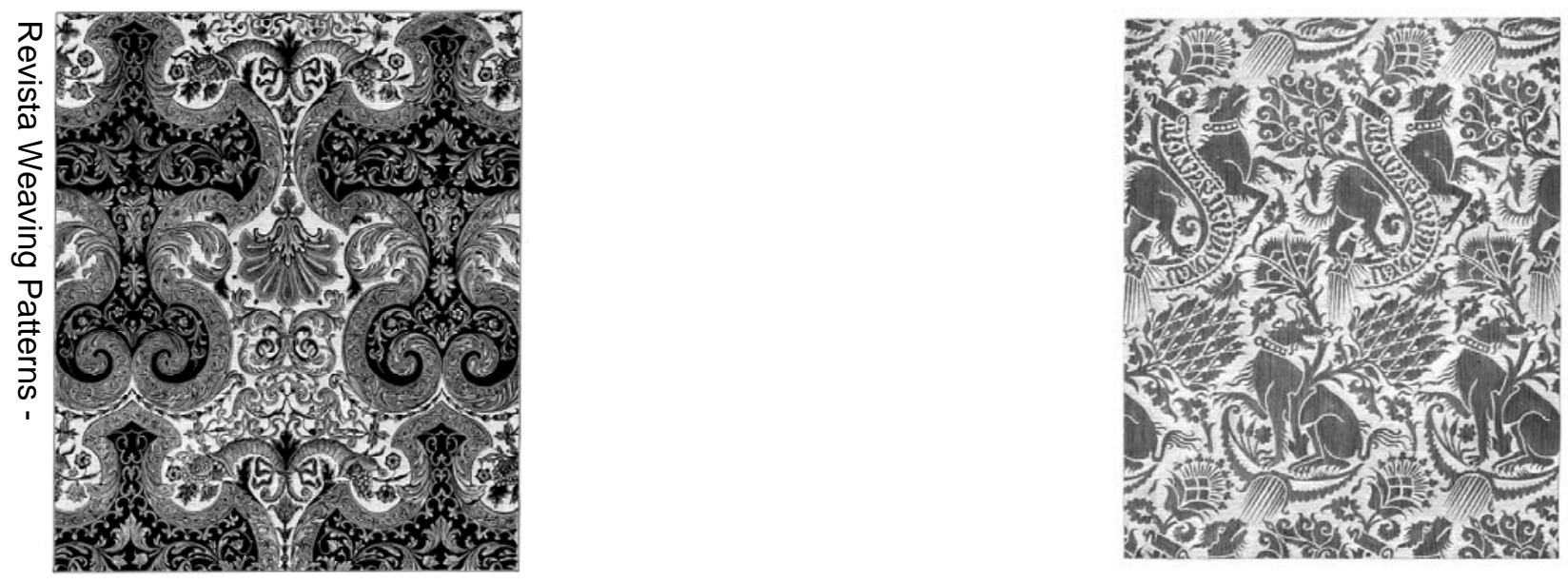
Em meados do século XIII, as tecelagens de Regensburg e Colônia demonstravam a influência de certos protótipos de padronagem oriental, que gradualmente foram sendo adaptadas ao gosto europeu, rompendo-se assim um padrão préestabelecido. Na Itália, durante o século XIV este fenômeno pôde ser observado com 0 desaparecimento dos temas animais e divisões arquitetônicas e com o florescimento das estampas de flores cada vez mais estilizadas. A moda dos tecidos de estampas florais se tornou

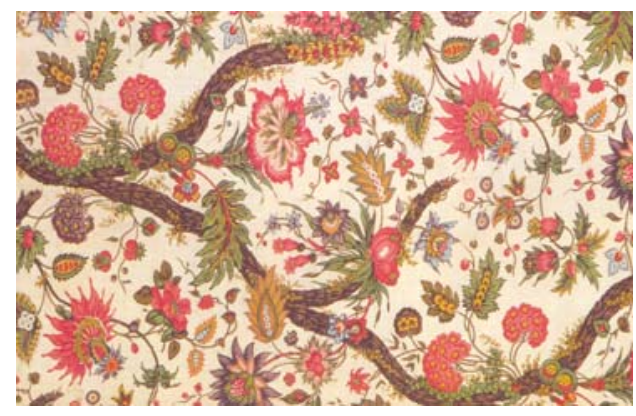
generalizada desenvolvendo-se, especialmente, nas regiões de Genova e Florença.

No século XV os padrões florais assumiram dimensões exageradas, com grandes romãs ou cardos estampados entre linhas sinuosas.

Durante o século XVIII, as padronagens dos tecidos passaram a sofrer a influência das grandes descobertas e viagens de exploração e as importações dos tecidos orientais tornaram-se lugar comum. Cada vez mais começaram a ser encontradas exemplos da flora exótica em padronagens que exibiam flores e frutos desconhecidos na Europa até então.

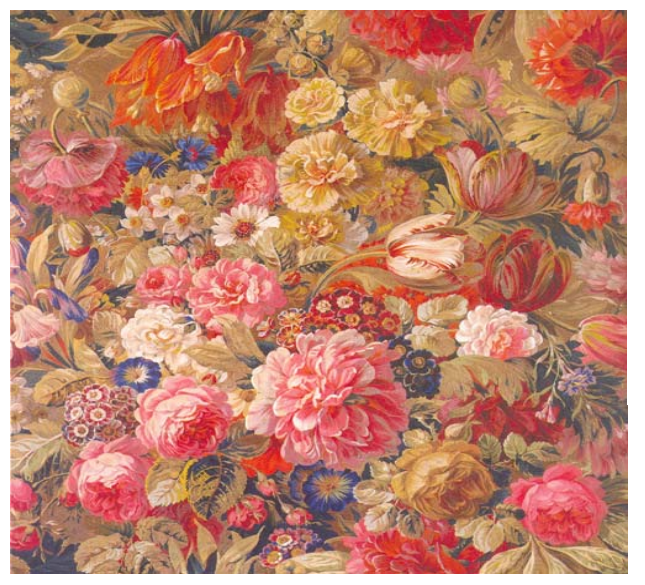

Flores como o crisântemo, acabaram por criar o gosto pelas padronagens florais exóticas. Isto se manteve até o final desse século, quando a moda voltou às suas origens ocidentais, com padronagens mais simples, como margaridas, papoulas e rosas. Durante o século XIX, essas padronagens florais realísticas se mantiveram populares.

Entretanto, algumas padronagens florais formais e estilizadas em algodão acetinado foram desenvolvidas durante o período Art Déco. 

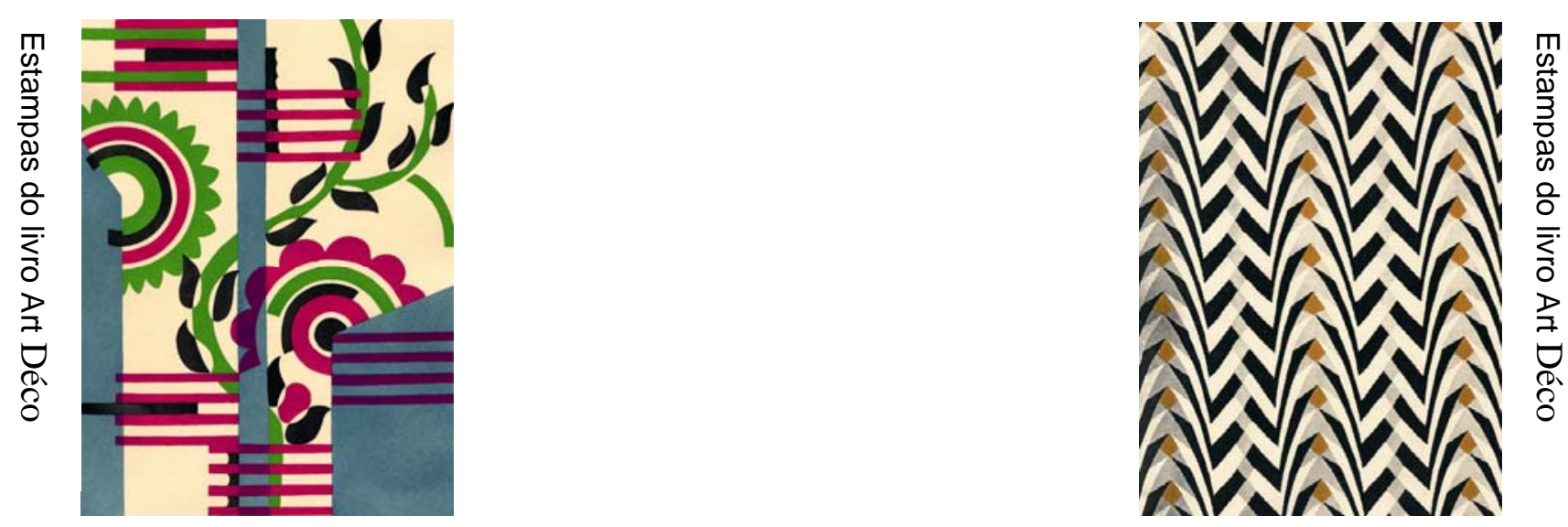

O final do século vinte trouxe um revival do estilo vitoriano de flores em design natural. Tecidos estampados com flores miúdas, ainda tão comuns nos dias de hoje, surgiram por volta de 1800, nos Estados Unidos, com a adoção das primeiras máquinas de estampar. A empresa Thorp, Siddel and Company, instalava em Philadelphia a primeira dessas máquinas em 1810. Dentro de poucos anos passava a existir uma grande quantidade de empresas de estamparia, mesmo no pequeno estado de Rhode Island.

Entre estas, exemplos de tecidos da Allen Print Works, da Clyde Bleachery e da Print Works ainda podem ser encontrados no Museum of American Textile History em North Andover, Massachussets. A padronagem era de pequenas flores espalhadas por toda a superfície do tecido, que acabou sendo conhecido como Liberty (Tradicional fabrica de tecidos e loja na Inglaterra, até hoje existente)

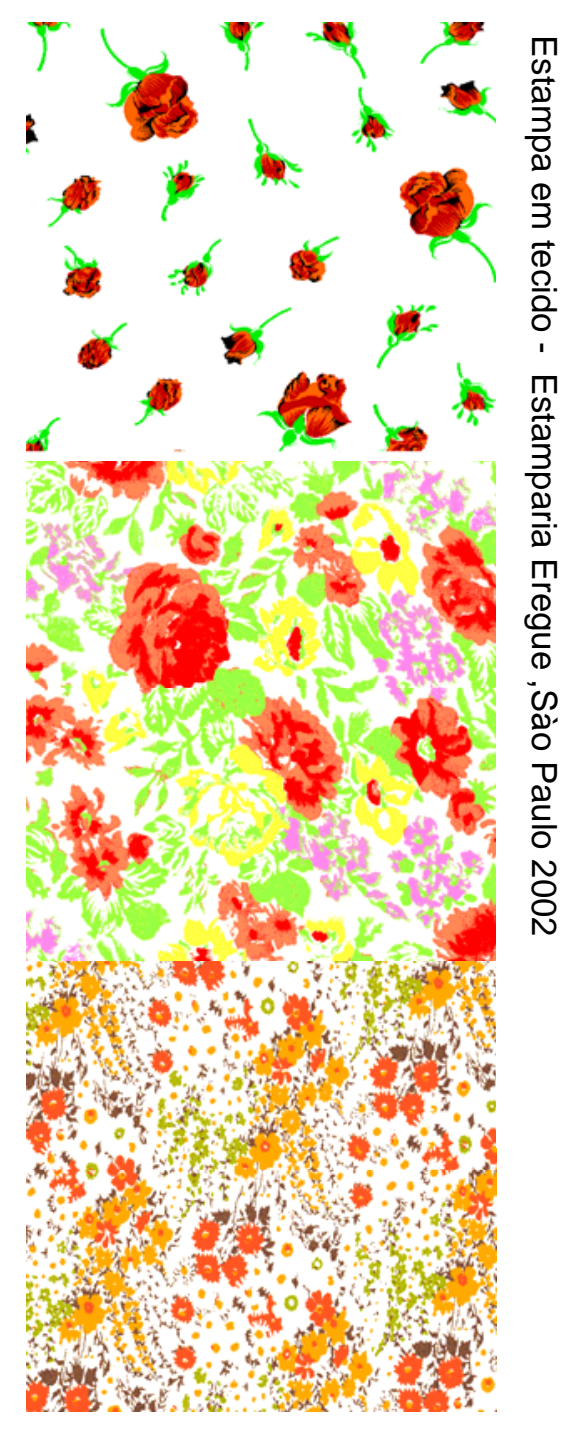

Durante o período barroco francês e inglês, as padronagens se tornaram bastante complexas, usando técnicas sofisticadas e cores seda e algodão, realistas. Já o estilo rococó, no início do século XVIII produziu um tipo mais informal de padronagem pictográfica, geralmente frívola e extremamente colorida, em apresentando design em estilo oriental com cenas de paisagens árabe e mourisca. 
A expansão do comércio além-mar incentivou a moda da padronagem pictográfica, apresentando paisagens e povos nativos como as do Havaí.

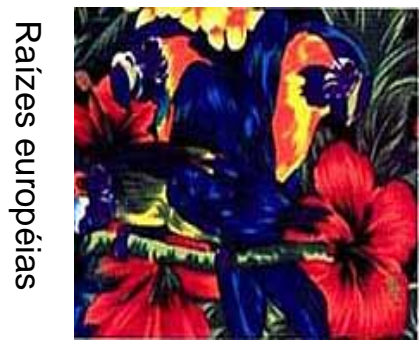

A partir de meados do século XVIII, essas padronagens voltaram a se tornar menos populares, com a preferência se voltando a cenas mais delicadas, como as imagens dos

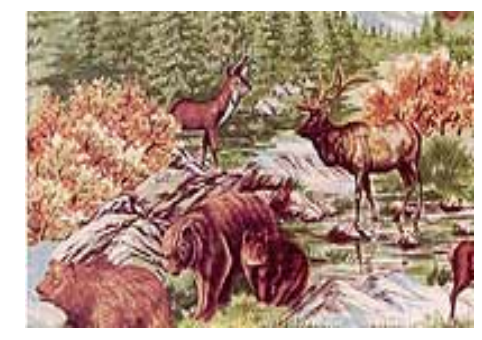
campos franceses e ingleses.

As padronagens pictoriais adquiriram um tom refrescante no início do século vinte, quando o movimento Art Nouveau introduziu elegantes figuras e plantas alongadas.

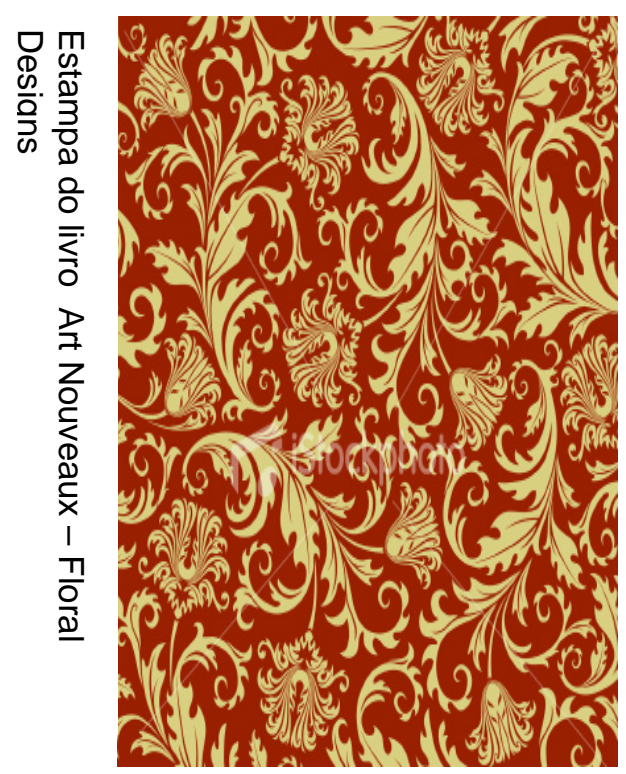

O movimento Arts and Crafts, entretanto, tornou a explorar um design mais medieval, apresentando formas humanas em meio a fundos florais.

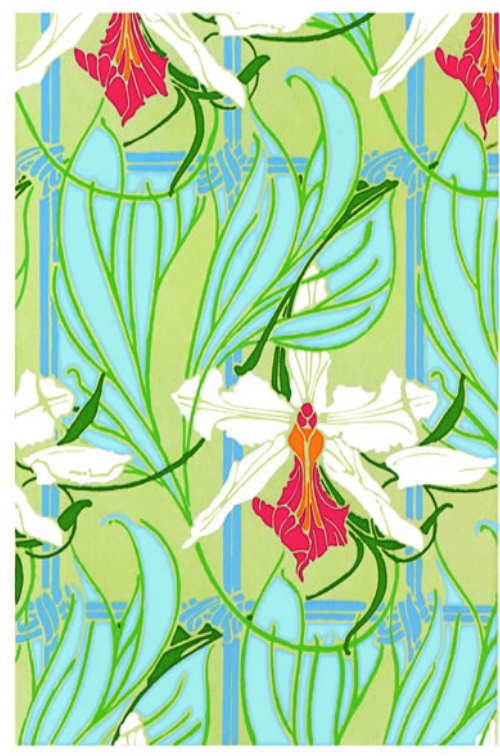
cisnes, labaredas e outros elementos. Teve início na Inglaterra em 1880 com William Morris (1834 - 1896) e Arthur Heygate Mackmurdo (1852 - 1942), artistas que atuavam na produção tipográfica e de têxteis ${ }^{5}$.

No início do século vinte, os designers modernistas e Art Déco movimento popular internacional de design de 1925 até 1939, que afetou as artes decorativas, a arquitetura, design interior e desenho industrial, assim como as artes visuais, a moda, a pintura, as artes gráficas e cinema. Este movimento foi, de certa forma, uma 
mistura de vários estilos (Ecletismo) e movimentos do início do século $X X$, incluindo Construtivismo, Cubismo, Modernismo, Bauhaus, Art Nouveau e Futurismo, raramente usavam tecidos com padronagens pictográficas. Esse tipo de padronagem sofreu um revival apenas no final do século XX.

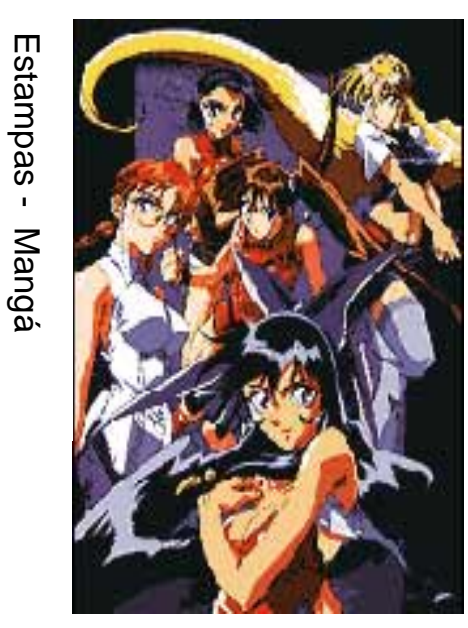

Outro fenômeno importante do final do século $X X$ são as padronagens $^{6}$ inspiradas na arte Mangá, os famosos quadrinhos japoneses. À primeira vista estes parecem ser uma versão oriental das histórias em quadrinhos ocidentais. Isto é uma realidade parcial, pois ainda que alguns aspectos do mangá tenham sido extraídos do ocidente, uma vez que Osamu Tezuka, o "pai" do mangá tenha sido influenciado por Disney e Max Fleisher, sua estrutura básica pode ser encontrada na arte japonesa.

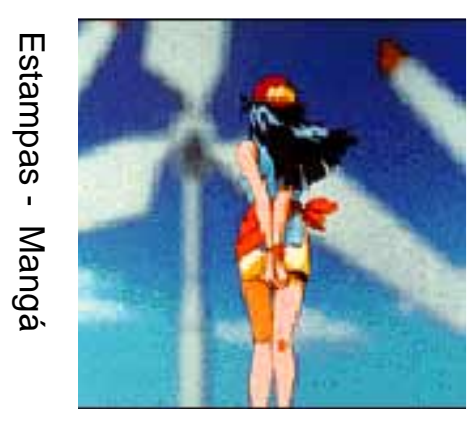

Desde o início do século VII, a cultura japonesa segue os princípios da cosmologia chinesa. Os 5 elementos: fogo, água, terra, madeira e metal, associam-se aos pontos cardeais, às estações do ano e às cores primárias e intermediárias numa fusão de idéias que acabou se refletindo em um elaborado sistema conhecido por kasane-iro no qual

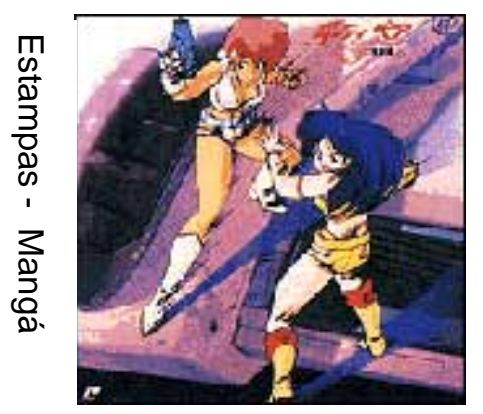
os kimonos passaram a ser usados em camadas de graduação de tons e texturas, com nomes como "camadas azáleas". As propriedades medicinais dos pigmentos vegetais e o simbolismo inerente nas cores criaram a base de um padrão estabelecido para o uso da moda oriental que progrediram linearmente, seguindo um padrão coerente até a arte mangá dos dias de hoje.

Os padrões dos tecidos usados pela corte imperial japonesa eram chamados yüsoko, e estes se tornaram os padrões básicos para todas as variações usadas a partir de arabescos, vinhas, xadrezes, círculos entrelaçados e medalhões com flores, plantas, pássaros e insetos. As primeiras estampas "livres" apresentavam plantas e animais, reais ou míticos, além de objetos, geralmente agrupados em 
combinações sazonais. Durante as guerras do período Hei, a situação econômica tornou a indústria têxtil inviável e o Japão voltou-se à China para a obtenção da tão necessária seda, renovando o contato com a dinastia Ming.

A partir de 1544, mercadores europeus introduziram mercadorias estrangeiras em terras japonesas. Entretanto, em 1638, a capital do Japão foi transferida para Edo (hoje Tókio) e promoveu-se uma política de isolacionismo, cortando o Japão das influências culturais externas. Isto possibilitou um desenvolvimento artístico único, sem influências, que culminou, no século 17 no Ukiyo-e ou "imagens do mundo flutuante". Pode-se dizer que o Ukiyo-e é a expressão primeva da arte Mangá. São as estampas feitas com blocos de madeira, criadas durante a estabilidade próspera do Shogunato Tokugawa, que acabaram exercendo profunda influência sobre o Impressionismo e Pós-Impressionismo na Europa.

Dentre os trabalhos mais significativos da arte Ukiyo-e destacam-se os de Hishikawa Moronobu (1618-1694) em estampas preto e branco (chimai-e); Suzuki Harunobu (1725-1770) cujo trabalho é associado ao primeiro nishiki, ou estampas policromáticas lembrando brocado; Ando Hiroshige (1797-1858) conhecido por suas ilustrações de viagens; Kitagawa Utamaro (1753-1806) especialista em bijin-ga, "beleza feminina"; Katsushika Hokusai (1760-1849) conhecido por suas dramáticas paisagens marinhas em azul e branco e Utagawa Kuniyoshi (1798-1861) que trabalhava com coloridas cenas de ação apresentando animais e pássaros daquela época. Os padrões principais do yüsoko apresentavam as seguintes versões: treliças diagonais; losangos.

\subsection{Definição e Função}

Definição

A palavra é inglesa, printwork, que literalmente significa trabalho pintado, padrões impressos em tecidos. Abaixo as definições de profissionais do Setor para entrevistados pela autora para o tema: 
Segundo Andrade Filho e Ferreira (1997) "Estamparia é o beneficiamento têxtil que tem por finalidade imprimir desenhos coloridos nos tecidos".

Para Nelson da Silva, estilista da Tecelagem Coteminas "Estamparia consiste na impressão de desenhos ,sobre tecidos ,onde o designer se ocupa com a criação dos desenhos adequados aos processos técnicos de estampagem".

"Estamparia pode ser considerado como um tingimento local" de acordo com Sr. José Macedo, presidente da Sintequimica.

Estampar ou imprimir designa de maneira genérica diferentes procedimentos que têm como finalidade produzir desenhos coloridos - e também brancos ou monocromáticos - na superfície de um tecido, como se fosse uma pintura localizada que se repete ao longo da metragem da peça e aplicada no seu lado direito.

Essas figuras podem ou não possuir contornos, variantes que estão intimamente ligadas aos modismos e tendências de cada época. Segundo Pompas (1994):

"Uma definição genérica e normalmente aceita sobre estamparia têxtil é que esta consiste nos procedimentos utilizados para se obter um motivo, em uma ou mais cores, que se repete com regularidade sobre 0 fundo. Os acabamentos baseados em estampas representam um meio importantíssimo para agregar valor aos tecidos lisos".

Função

A finalidade da estamparia é dar vida ao tecido, muitas vezes os tecidos com defeito são recuperados por este processo, já que os desenhos cobrem o defeito indesejável.

Na moda, a função da estamparia é prover cunho estético à roupa ou coleção que será confeccionada. É agregar valor ao tecido.

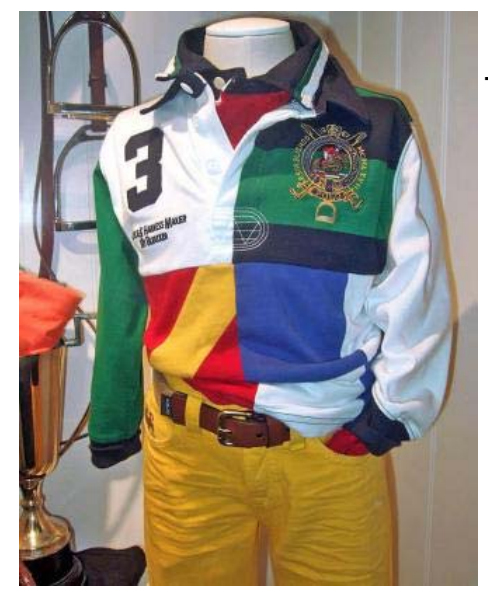



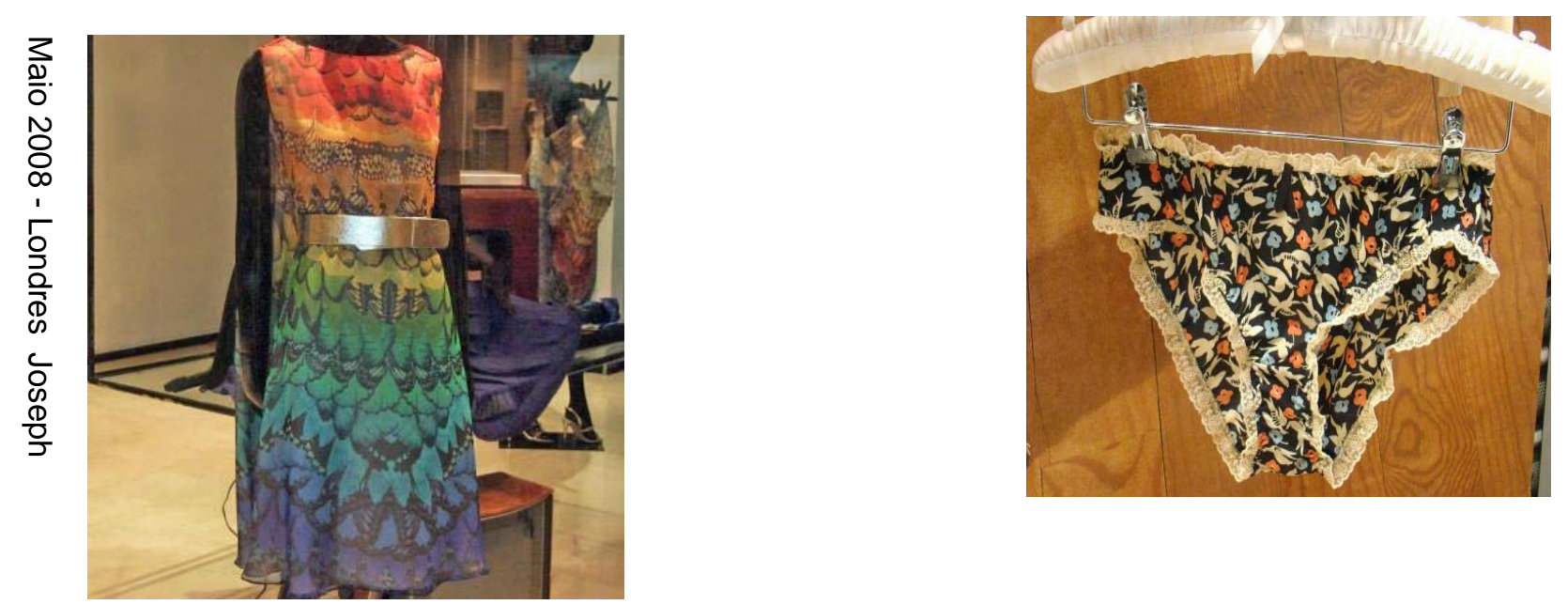

Segundo Ana Milliet, do Studio Milliet, a função de estamparia é personalizar, criar uma identidade na marca de uma etiqueta. Por exemplo, criar um estilo de desenho e desenvolver este tema de acordo com as estações.

Outra função importante é direcionar seu uso com variações de cores. Por exemplo: desenhos de lingerie exigem desenhos mais românticos, infantis, desenhos alegres, Já os masculinos exigem desenhos clássicos, mais sóbrios, desenhos pequenos.

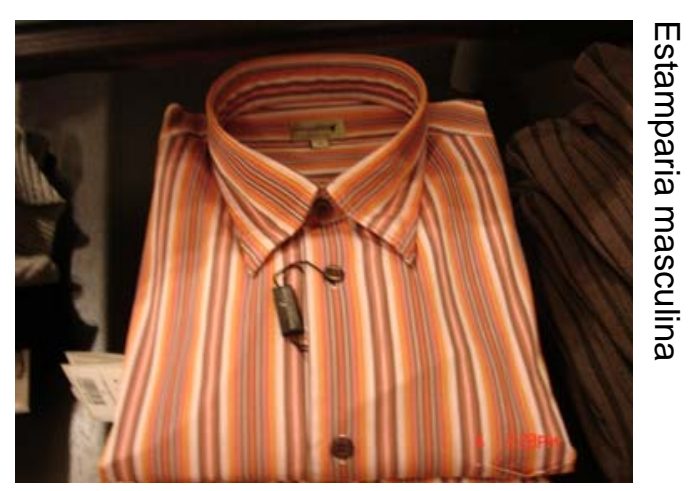

Imprescindível ter pleno conhecimento técnico dos processos de coloração e o efetivo conhecimento prévio das tendências de moda para determinada estação antes da escolha das cores que serão trabalhadas.

O entendimento do comportamento do mercado, e particularmente no Brasil, onde existem climas tão variados dentro de uma mesma estação, gerando confecção de artigos em tecidos e padronagens completamente diferentes num mesmo período, é fator importante a ser considerado durante a função da estamparia. 
Segundo Lipovetsky (1989), a fase inaugural da moda é compreendida da metade do século XIV à metade do século XIX, revelando seus traços sociais e estéticos mais característicos, e servindo à aristocracia vigente. Os burgueses, por sua vez, passaram a copiar as roupas dos nobres, relatando com isso o caráter estratificador através das distinções de classe e dos modos de vestir: iniciava-se a moda enquanto gosto pela troca freqüente de trajes. Um destes momentos aconteceu no início do século $X X$, entre o costureiro Paul Poiret, célebre por libertar as mulheres do espartilho e por rejuvenescer a ilustração de moda, e o artista francês Raoul Dufy. Poiret, que coleciona obras de arte e vive em um cenário faustoso e refinado, cercado de poetas e de pintores como, por exemplo, Paul Iribe, Erté, Constantin Brancusi, Henry Matisse, Robert Delaunay, Pablo Picasso entre outros. Ele próprio cria trajes para o teatro e balé, subvencionando a criação artística.

Poiret oferece a Dufy, a possibilidade de criar padrões têxteis no seu ateliê de impressão sobre tecidos chamado de "a pequena usina". Lá Dufy desenha os motivos, grava os quadros de impressão, estuda as técnicas químicas necessárias e passa ele próprio a estampar suas criações, que contribuem para o sucesso das coleções de alta costura de Poiret. A experiência será de curta duração - o industrial têxtil Bianchini, tendo descoberto este novo talento, lhe propõe meios industriais mais dignos.

Os padrões decorativos empregados nessas estampas eram predominantemente geométricos e lineares, inspirados na arte popular, rica em motivos deste gênero. Stepanova atuou como professora em "Vkhutemas - Altas Oficinas Técnicas e Artísticas do Estado Soviético".

Estabelecendo a relação moda e design de forma tão integrada às questões estéticas e funcionais, "Sonia Delaunay assim como Varvara Stepanova, associou a vanguarda da arte à vida cotidiana desenvolvendo objetos de uso a partir da visão política e artística dos movimentos e correntes as quais pertenciam" (MOURA, 2008). 


\title{
2.3 Seqüências cronológicas para serem analisadas e pesquisadas as Tendências de Moda
}

\author{
TENDÊNCIA do Lat. tendentia \\ s. f., inclinação; propensão; tende a mover-se \\ em determinado sentido.
}

A proposta deste estudo, neste capítulo, é analisar os significados e os usos que o campo da moda conferiu às tendências.

[...] Portanto, não é demais afirmar que os termos moda, fenômenos de moda e consumo são praticamente intercambiáveis entre si. Nesse sentido, conhecer o universo, os significados e o funcionamento das tendências da moda tornou-se estratégico para uma ampla gama de empresas, muito além da indústria têxtil e de confecção. (Dário Caldas)

\begin{abstract}
A tendência de moda é a base do que fazer em termos de têxtil e vestuário. É desenvolvida por um conjunto de protagonistas, que têm, além dos interesses econômicos, a afirmação de criadores reconhecidos e de sinais captados sobre os desejos e as necessidades dos clientes e consumidores. (Gabriela Jobim e Manuela Neves)
\end{abstract}

Tendo em vista que o "negócio de moda" é sazonal, em função da existência de três estações climáticas bem caracterizadas, e que as mesmas ocorrem em períodos opostos ao longo do ano nos hemisférios norte e sul, as tecelagens brasileiras em seu esforço de planejamento de desenvolvimento de novos produtos devem estar atentas a dois fatores importantes: o fiel cumprimento do cronograma sazonal para lançamento das distintas coleções de verão, alto-verão e inverno no hemisfério sul bem como o conhecimento das tendências "ditadas" pela moda européia, em especial de Paris, que ocorre com seis meses de antecedência.

Neste sentido, a fase inicial do planejamento de desenvolvimento de novos produtos na indústria têxtil brasileira, em particular o lançamento de tecidos femininos de moda, reside na definição do período de exposição ou lançamento da Coleção 
Verão de 2009, que ocorrerá no mês de agosto de 2008, o que determina que esta etapa de pesquisa de tendências deve ocorrer no mês de maio de 2008 , de acordo com os Anexos A e B.

Em termos gerais, é importante estabelecer uma sistemática de previsão de tendências de moda que deve se basear tanto nos anseios da demanda futura, que pode ser percebida pelos chamados "sinais da sociedade", como pelas possibilidades da oferta, que pode ser inferida em função da capacidade de produção dos agentes empresariais da cadeia têxtil. Assim, esta sistemática deve compreender uma rede de informações sobre os desejos dos consumidores.

\section{Sistema de Previsão de Tendências}

A Pesquisa de tendências é uma atividade que tem de lidar com as capacidades de percepção e de leitura de sinais da sociedade, quase sempre incipientes, tendo como limites os interesses e as possibilidades dos parceiros da indústria. Para melhor entendimento do sistema de previsão de tendências, devemos esclarecer os elementos que o integram.

Segundo Neves (2000) são:

- A estrutura dos mercados

- O calendário, cronograma de criação industrial têxtil

- A rede de informação

- A estratégia de venda

- Os consumidores

A estrutura dos mercados

Como fonte de informação interna, a estrutura dos mercados é de extrema importância, pois se encontra num cenário de profunda e permanente interligação que reflete nas suas escolhas de compra.

O calendário: cronograma da criação industrial têxtil

No momento em que é divulgado um calendário em que se traçam datas precisas para os ciclos de desenvolvimento de novos produtos, com antecipação das 
propostas para uma determinada estação, são fixados parâmetros para atuação dos parceiros da fileira têxtil e do vestuário em todo o mundo.

A apresentação de duas coleções por ano impõe um sistema complexo de gestão de informação e das intervenções dos diversos agentes que deverá ser coordenado.

A moda passa por vários níveis, funciona através de um extenso mecanismo industrial que começa na produção das fibras e dos fios que vão compor tecidos e vai até a confecção sob forma de roupas e a comercialização no varejo.

A rede de informação

Quanto maior é o número de opções de informações, mais difícil é a triagem e escolha, sendo particular a cada tipo de produto que se pretende desenvolver. Sendo assim, tem-se cada vez mais meios de pesquisa ao alcance, informação mais vasta, mais abrangente e até mais dispersa.

Deve-se ressaltar a importância do acesso a todos os meios de informação como uma ferramenta não apenas útil, mas necessária, de consulta e atualização permanentes.

A flutuação das tendências sociais e de mercados é cada vez maior e mais forte, refletindo diretamente na mudança constante das mais variadas tendências de design e moda que nos deparamos a todo o momento.

Todo movimento de moda começa na Europa com dois anos de antecedência. "Pensar sobre moda é, inevitavelmente, incluir Paris. Escrever a história da moda é, obrigatoriamente, contar parte da história de Paris" (BRAGA, João). A seguir descrevemos como tem início a tendência geral de moda em vestuário.

\subsubsection{Cores - Intercolor}

Organismo com sede em Viena (Áustria) que define com dois anos de antecedência as cores definitivas e internacionalmente aceitas para a indústria têxtil e confecção. Esta definição é elaborada com base nas propostas originais de cada país, discutidas em nível de um grande fórum, movimentando um mundo milionário, em especial os principais fabricantes de anilinas internacionais como: Bayer, Basf, Ciba, Clariance, entre outros. Tendências de cores visam aos interesses de grandes monopólios de corantes. 


\subsubsection{Fios Pitti Filatti (Firenze), Expofil (Paris)}

São realizadas duas feiras por ano (primavera/verão e outono/inverno), onde são lançados os novos tipos de fios naturais, sintéticos, artificiais, ecológicos, em que cada fabricante já lança a sua cartela de cores e as sugestões de construções de tecidos, de acordo com os segmentos e seu uso.

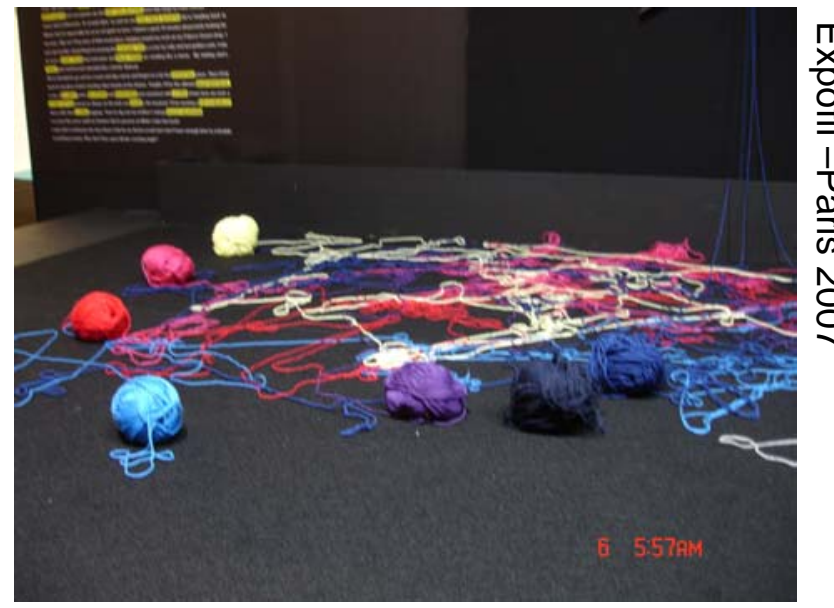

Os fabricantes e estilistas de tecidos de todo o mundo visitam estas feiras, para comprar as matérias primas que servirão de pesquisa e inspiração para suas coleções. Os principais fabricantes de fios são: Tecilidea, E. Miroglio Yarns, Polienka, Sansung, Rhodia, DUPont, Invista, entre outros.

\subsubsection{Feiras de Tecidos - Moda Única (Milano), Premier Vision (Paris)}

Essas são as duas feiras mais importantes do mundo, sendo assim, á uma comissão que elenca quais empresas irão participar expondo seus produtos. Entre as empresas brasileiras que participam das feiras estão a Vicunha Têxtil, a Têxtil Santanense, a Corduroy Têxtil, Hudtelfa Têxtil, entre outras.

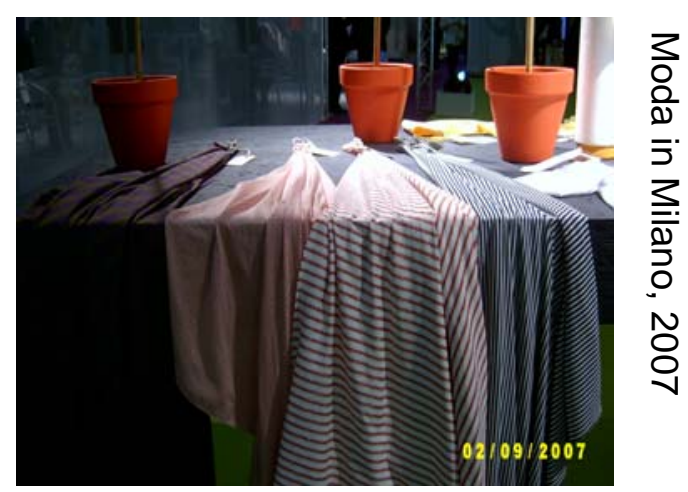

As feiras de tecidos são consideradas as mais importantes para os fabricantes de tecidos do Brasil, uma vez que estamos no hemisfério sul, estando a meio ano atrás do calendário de moda europeu.

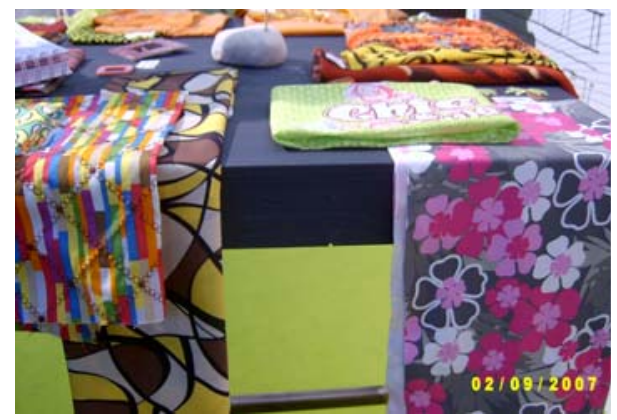


Nestas exposições encontramos confeccionistas e fabricantes de tecidos. São lançadas as novas tendências em tecidos, estamparia e é definida a cartela de cores para a próxima estação, ou seja, que compreende o período de um ano. Por exemplo, em Março 07 é lançado o verão 08 para os segmentos: masculino, feminino, infantil, jeans, lingerie.

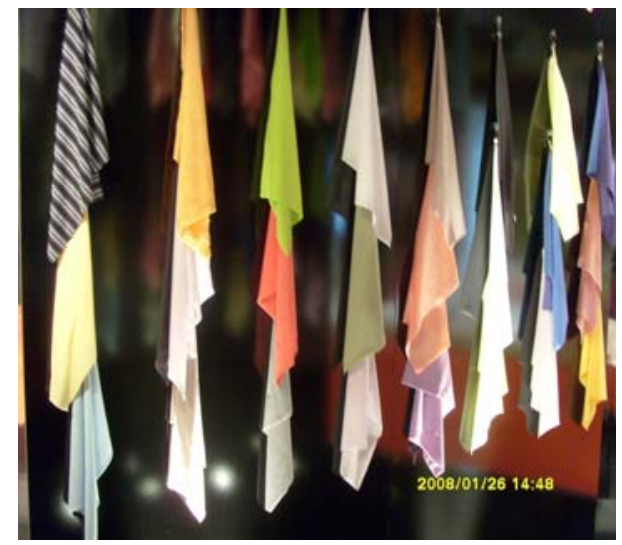

2.3.4 Feira do vestuário (duas vezes ao ano, primavera-verão e outono-inverno)

- Bread \& Butter - jeans wear - Barcelona;

- Prêt-à-Porter Fèminan - Feminino - Paris;

- Kids Fashion -Infantil-Paris;

- Salon International de la Lingerie - Lingerie - Lyon;

- Milano Collezioni Uomo - Masculino - Milano;

- Salon du Marroquerie - bolsas e acessórios - Paris;

- Première Class - moda jovem - Paris.
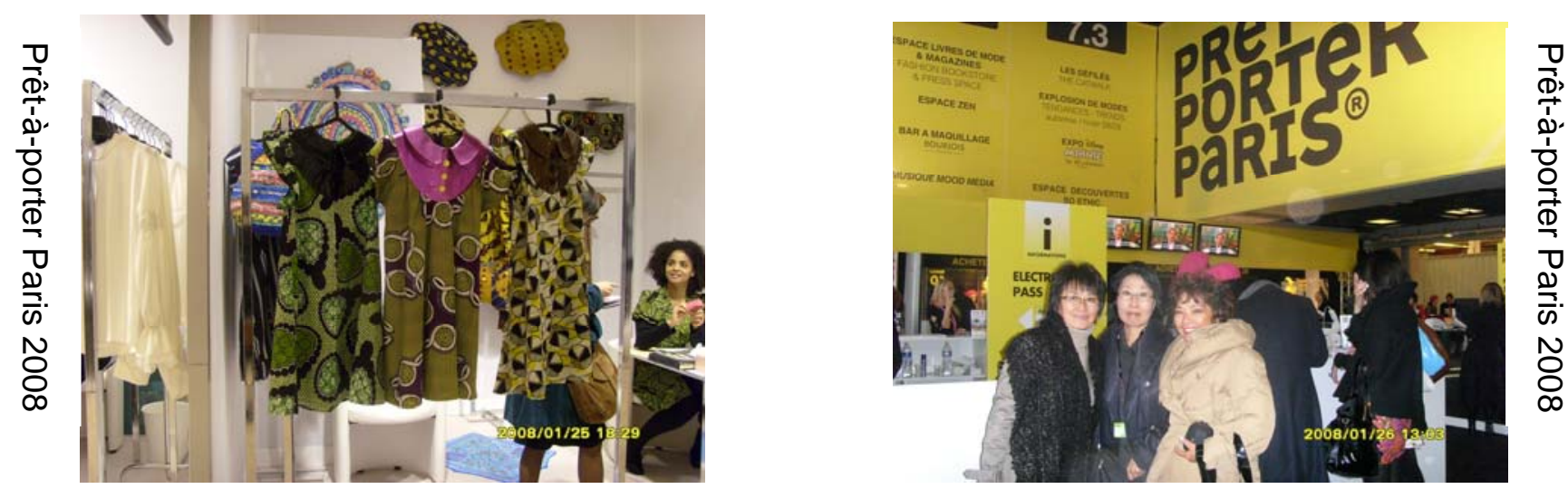

Nestas principais mostras, os fabricantes de diversos segmentos criam, reinterpretam as tendências, de acordo com seu perfil mercadológico. As marcas mais importantes lançam seus novos produtos nas principais mídias, como revistas de moda, outdoor, TV, Sites de moda. 


\subsubsection{Semana de Desfiles}

A idéia dos desfiles surgiu na metade do século XIX, com o costureiro Worth, inglês radicado em Paris, que utilizava manequins vivos para apresentar seus modelos de alta-costura às clientes.

A principal capital da Moda continua a ser Paris, que apresenta duas temporadas de desfiles: os de alta-costura os de prêt-à-porter.

Os estilistas de prêt-à-porter lançam suas coleções, mostrando suas propostas nas passarelas e o resultado de suas pesquisas e interpretações. Acontecem nas capitais de moda internacional:

- Paris - Kenzo, Chanel, Valentino ,Cloé,e outros

- Milão - Prada, Roberto Cavalli, Giogio Armani ,Gucci.

- Londres - Paul Smith, Stela Mc Cartney ,John Rocha.

- $\quad$ N. York - D. Karan ,Calvin Klein, Rosa Chá, Ana Sui.

- São Paulo - São Paulo Fashion Week.

\subsubsection{Vitrines nas principais e importantes lojas}

Segundo Baxter $(2000,43)$

As tendências e cores da moda são massificadas na forma de coleções [...] e chegas às lojas [...] uma pessoa que esteja usando o estilo do ano passado, pode ficar incomodado, por ser considerado socialmente inferior perante aos colegas. [...] Roupas que poderiam durar cinco ou seis anos são considerados obsoletas artificialmente em apenas um ano, forçando a um novo consumo, baseado na tendência social do estilo.

Uma vez que foram lançadas as coleções nas semanas de desfiles de prêt-à-porter e nas feiras de vestuário, cada loja ou magazine seleciona as suas linhas de produto e estilo lançando as coleções para a estação. As grandes lojas lançam os produtos através das mídias especializadas, em parceria com os próprios fabricantes e seus interesses mercadológicos. Por exemplo, canais de televisão, periódicos de moda (Elle, Vogue, Amica, Journal Du Textile, Le Figaro, entre outras). 


\subsubsection{Outras fontes de informação importantes}

- Internet: sites especializados (Style, Elle, Use Fashion, WGSN, Marie Claire, Word Fashion, Glamurama, blogs de moda (Mais Moda, Santa Mistura, Moda Sem Frescura, Oficina de Estilo).

- Livros, revistas e periódicos especializados:

No vasto leque das revistas de design de moda, há material com forte fator de intemporalidade e abrangência e, ainda, material com grande sazonalidade e especificidade.

- As revistas de moda são informações pontuais que expõem as coleções dos criadores. São materiais muito genéricos e altamente sazonais. São veículos de promoção e divulgação do mundo da moda, que estão em constante mutação, dados que se dedicam, sobretudo, a formar novas vontades no grande público. Exemplos: Collezioni, Elle, Fashion Trends, Vogue, Marie Claire, View Point, Textile Report, View Colour, Inspiration, Wallpaper, Harper`s Bazaar, Otto, L'Officiel, Textília, Cosmopolitan, Women's Wear Daily, Vanity Fair,Vogue, entre outros.

- Caderno de Informação de Tendência - Os cadernos de tendências designam vários materiais de informação em suporte físico, o que nos permite obter informações em várias fases da concepção do produto de moda. As informações encontradas nestes documentos, em todo ou em partes, integra e aborda, de uma forma sistematizada, informações sobre as seguintes matérias: conceitos e temas de design, gamas de cores divididas por temas e conjugações cromáticas, informações têxtil estética, informação de moda de vestuário, informação de moda de acessórios, etc. Exemplos: Carlin, Nelly Rody, Peclers, Promostyl, Huepoint Color, Pantone Preview, Woolmark Company, entre

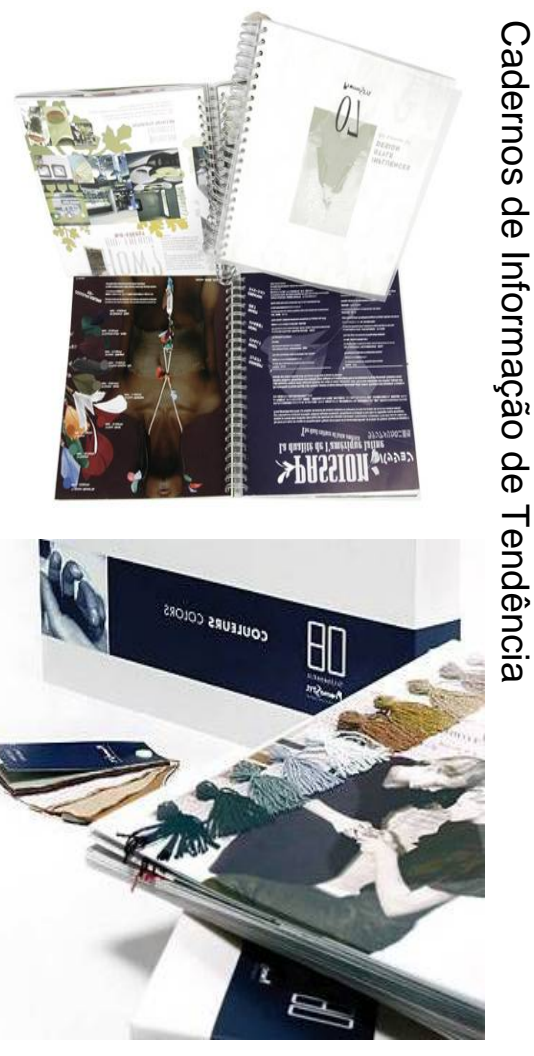
outros. 
- Bureaux de estilo internacional:

Os chamados Bureaux de style tiveram um papel fundamental na determinação das tendências durante as décadas de 1960 e 1970. O primeiro ateliê de estilo independente surgiu na França em 1957, Relations Textiles, de Claude de Coux. Os maiores e mais conceituados bureaux de style também são franceses: Promostyl de 1965, Máfia de 1967, Peclers Paris de 1970. Exemplos: Global Color Research, Italtex, Kjaer Global London, Nelly Rodi, Dominique Peclers, Promostyl, Fred Carlin, SIS, Sacha Pacha, Fashion Trends, Faces, Index, Kaigai, Design Intelligence, além dos citados anteriormente.

- Bureaux de tecido internacional: Alberto \& Roy, Creation Textile, Pressage Tissé, Tessitura.

- Seminários e Palestras

Tratando-se de informação de tendências, cada vez mais se destacam ações desta natureza. São geralmente lançadas e apoiadas por organismos que contam com a colaboração de grandes empresas, como ateliês de estilo, designers conceituados, órgãos ligados a feiras internacionais etc. Como exemplo a ABIT (Associação Brasileira da Indústria têxtil),considerada a mais importante do Brasil e a que mais bem pesquisa, faz palestras 4 vezes por ano.

Segundo Ellen Massucci Leite, coordenadora do Núcleo de Moda da ABIT,

Fazemos duas apresentações por ano para cada estação: "Fashion Preview" que apresenta uma análise dos direcionamentos criativos mostrados pelos desfiles nos principais pólos ligados aos lançamentos e, outra, "Last Minutes", na qual são confirmados as escolhas mais apropriadas para o varejo, de acordo com os vários segmentos de consumidores 
As apresentações são dirigidas ao público: tecelagens, malharias, estamparias, confecções, estilistas, estudantes e acontecem: palestras de primavera-verão são realizadas seguindo a seqüência: "Fashion Preview" em Novembro e "Last Minutes" em Fevereiro; palestras de outono-inverno: "Fashion Preview" em Abril e "Last Minutes" em Agosto.

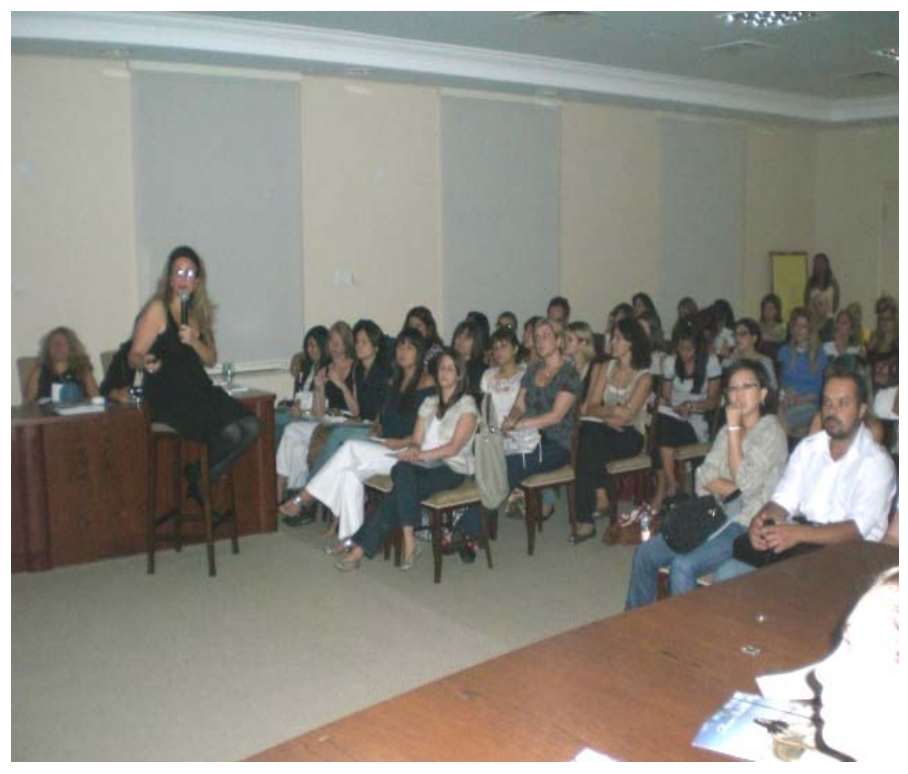

Estas apresentações são normalmente conceituais num primeiro plano, têxteis num segundo e de moda em terceiro plano, numa ação única ou num encadeamento de ações previstas para cada estação.

\subsection{Como tem início o projeto de uma coleção}

Gilda Chataignier $(1996,116)$ comenta em seu livro a opinião da designer carioca de moda Marília Valls sobre inspiração:

A primeira coisa que ela fala para quem quiser fazer uma boa coleção é simples: ter uma boa idéia. E essa idéia deve ser baseada no cotidiano, na rua, nas coisas que acontecem. 'As novidades geram o estado de criatividade' sentencia Marília.

Definir o "conceito" gerado a partir da filosofia da empresa, das pesquisas de mercado, trata-se da observação, análises quantitativas e qualitativas das necessidades e desejos de um determinado segmento.

Tendo em vista que o "negócio de moda" é sazonal, em função da existência de três estações climáticas bem caracterizadas, e que as mesmas ocorrem em períodos opostos ao longo do ano nos hemisférios norte e sul, as tecelagens brasileiras em seu esforço de planejamento de desenvolvimento de novos produtos devem estar 
atentas a dois fatores importantes: o fiel cumprimento do cronograma sazonal para lançamento das distintas coleções de verão, alto-verão e inverno no hemisfério sul bem como atento ao conhecimento das tendências "ditadas" pela moda européia, em especial as de Paris, o que ocorre com 6 meses de antecedência.

Neste sentido, a fase inicial do planejamento de desenvolvimento de novos produtos na indústria têxtil brasileira, em particular o lançamento de tecidos femininos de moda, reside na definição do período de exposição ou lançamento, por exemplo, da Coleção de Verão de 2009, que ocorrerá no mês de agosto de 2008, o que determina que esta etapa de pesquisa de tendências deve ocorrer no mês de maio de 2008.

Uma vez definido, tem início o planejamento e desenvolvimento de estilos, disponibilidade de matérias-primas, cores, custo e a infra-estrutura da empresa. São principalmente lançadas coleções três vezes ao ano, primavera-verão - de janeiro a fevereiro, alto-verão - de maio a junho e outono-inverno de agosto a setembro, e a cada mês mini-coleções, devido à efemeridade mercadológica.

"Hoje as pessoas não são racionais e sim emocionais, tem de ser elaboradas justificativas que dêem embasamento, e é preciso que o Marketing monte uma estratégia para o cliente final".

"Quebrado pela influência de uma cultura de massa, está calcada por poucos meios de comunicação, como o caso da TV Globo, se determinada personagem da novela cai nas graças do espectador, ou seja, a produção de vestuário nas novelas", disse o Eng ${ }^{\circ}$ Paulo dos Anjos, Diretor da Paulo dos Anjos Especialidades Têxteis e Design Ltda.

Para Jones (2005) escolher tecidos adequados para o tipo de produto a ser fabricado é a chave do sucesso na criação de moda, porque a adequação de um tecido para a criação provém de combinações de fios, construção, peso, textura ,cor toque e estampa, como também de fatores adicionais que poderão complementar, como os acabamentos especiais (são todo tipo de tratamento nos tecidos semiacabados) que dão um aspecto diferente aos tecidos. 
A seguir os itens para ser desenvolvida uma coleção de tecidos e estampados:
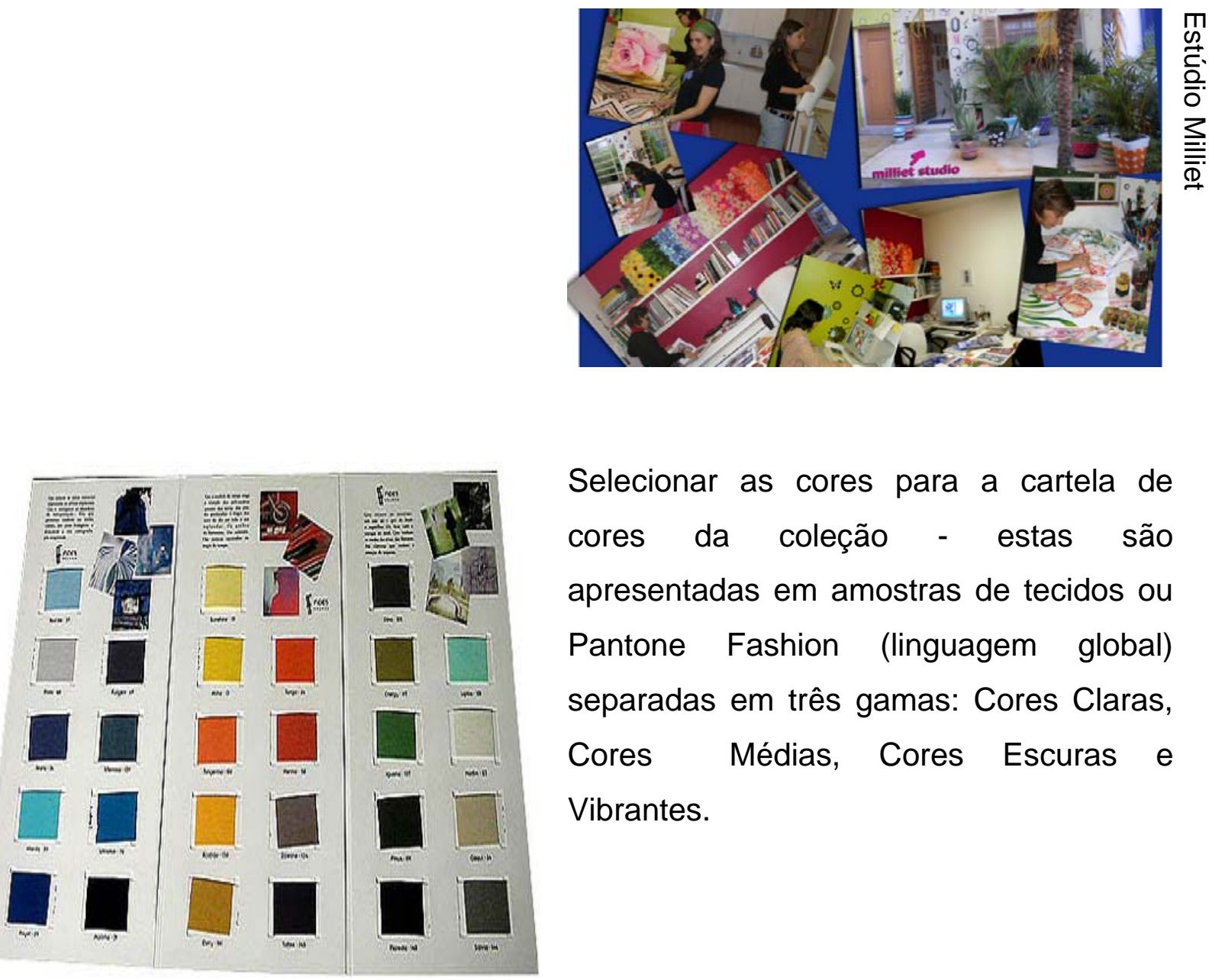

Selecionar as cores para a cartela de cores da coleção - estas são apresentadas em amostras de tecidos ou Pantone Fashion (linguagem global) separadas em três gamas: Cores Claras, Cores Médias, Cores Escuras e Vibrantes.

A classificação da gama de cores é justificada pelo custo das anilinas, e facilita o departamento comercial. A cartela de cores é geralmente composta por 24 cores. As cores selecionadas vão para o laboratório químico onde o técnico faz as provas de cores e as receitas para serem processadas em escala industrial.

- Análise de produto dos principais concorrentes

- Análise da coleção passada

- Levantamento de estoques de fios e tecidos

- Filtragem das tendências de Moda

- Reunião com executivos das fábricas, como: gerente de tecelagem, tinturaria, estamparia, PCP(planejamento/controle/produção), gerentes de produto, vendas, marketing.

- Definir as Estratégias de Produtos 
Selecionar os tecidos e desenhos de estamparia para que sejam utilizados todos os tipos de teares, maquinários de tinturaria e estamparia. Sobre o tema, abaixo os tipos de teares e maquinários existentes em uma indústria, de acordo com entrevista concedida à autora pelo Eng ${ }^{\circ}$ Gustavo Carvalho- Supervisor de Produção da Vicunha Textil-Americana.

\section{Tecelagem - Tipos de teares}

Jato de água Nissan pode fazer tecidos sintéticos - 30 máquinas

Jato de Ar Dornier pode fazer tecidos mistos, sintéticos, naturais $(100 \%$

Algodão) - 30 máquinas

Tear de pinça Dornier pode fazer tecidos mistos, sintéticos, naturais

(100\% Algodão), decoração, camisaria - 27 máquinas

Produção de tecidos leves para moda aproximada por tear:

Jato de água $=8.000 \mathrm{~m} / \mathrm{mês}$

Jato de $\operatorname{Ar}=10.000 \mathrm{~m} / \mathrm{mês}$

Pinça $=6.000 \mathrm{~m} / \mathrm{mês}$

\section{$\underline{\text { Tinturaria }}$}

Lavadeira para purga -2 máquinas

Jets para tingimento- 5 máquinas para tingir polyester, tecidos naturais, poliamida.

Rama para acabamento - 4 máquinas,

Máquina rotativa para estampar- 2 máquinas

- Cálculo dos custos

- Formação do preço final

- Acompanhar e orientar o desenvolvimento de produtos nas Fábricas

- Confecção de mostruários para Vendas

- Processo de apresentação das coleções

- Avaliação e acompanhamento dos volumes de vendas

Este item é muito importante, pois permitirá identificar os tipos de tecidos, estampas, cores mais comercializadas e que serão úteis para orientar os 
lançamentos de novos produtos (novos tecidos) ao longo das estações (ANEXO C).

Em termos gerais, é importante estabelecer uma sistemática de previsão de tendências de moda que deve se basear tanto nos anseios da demanda futura, que pode ser percebida pelos chamados "sinais da sociedade", como pelas possibilidades da oferta, que pode ser inferida em função da capacidade de produção dos agentes empresariais da cadeia têxtil. Assim, esta sistemática deve compreender uma rede de informações sobre os desejos dos consumidores.

Identificar as principais fontes de tendências que influenciarão a moda verão em 2009, que incluem a participação de vários setores.

- Assessoria de Imprensa - cumpre enviar release aos veículos especializados em moda, como: Revista Textília, World Fashion; Érica Palomino, Glamurama, Mais Moda.

- Acompanhar e analisar as vendas da coleção - este processo de pesquisa, desenvolvimento, até o lançamento da coleção é necessário que o produto tenha qualidade e agilidade.

A fase de criação e desenvolvimento de produto de moda ainda não compreende todos os itens necessários para que o produto seja considerado de qualidade, apesar dos investimentos em pesquisa e desenvolvimento adequados ao nosso país, com maquinários de última geração, é necessário agilização produtiva, pois hoje estamos num mundo global onde as informações são muito rápidas. O mercado exige isso, e as próprias tendências de moda, segundo Caldas (2004) duram pouquíssimo tempo no meio "fast-fashion".

Atualmente, a concorrência crescente, a entrada de empresas internacionais no mercado interno e o rápido acesso à informação motiva as empresas a buscar uma diferenciação dos seus artigos, não esquecendo que o ciclo de vida do produto de moda, da criação até a comercialização é curto, por mais inovador e interessante que este seja. 
$\mathrm{Na}$ moda, qualidade e criatividade na criação e desenvolvimento de um novo produto são importantes, considerando que essa indústria possui algumas peculiaridades. As etapas de fabricação de uma peça do vestuário não se comunicam entre si, são fragmentadas. O produto de moda demora dois anos para ficar "pronto", desde a fiação até o varejo, mas renova-se constantemente. Porém, novas tecnologias e novos métodos de gestão da produção estão possibilitando uma redução da periodicidade destes ciclos da moda.

\footnotetext{
${ }^{1}$ Revista Química Têxtil n43 - Ano XIX - jun 1996

${ }^{2}$ Apostila de estamparia da CLARIANT, Laboratório Têxtil, 1995, rev1

${ }^{3}$ Idem anterior

${ }^{4}$ De acordo com Raízes da padronagem dentro da tecelagem Européia no http://www2.uol.com.br/modabrasil/forcas_moda/estampa/

${ }^{5}$ http://www.pitoresco.com.br/art_data/art_nouveau/index.htm

${ }^{6}$ Extraído de Raízes da padronagem dentro da tecelagem Européia no http://www2.uol.com.br/modabrasil/forcas_moda/estampa/
} 


\title{
3 ESTAMPARIA - FUNDAMENTOS TEÓRICOS
}

\subsection{Histórico da Cor}

\begin{abstract}
A cor é um fenômeno fascinante. Sua presença no mundo visível exerce incontestável atração sobre nós, despertando sensações, interesse e deslumbramento. A cor representa uma ferramenta poderosa para a transmissão de idéias, atmosferas e emoções, e pode captar a atenção do público de forma forte e direta, sutil ou progressista, seja no projeto arquitetônico industrial (design), gráfico, virtual (digital), cenográfico, fotográfico ou cinematográfico, seja nas artes Plásticas. ${ }^{1}$
\end{abstract}

No mundo fashion da estamparia têxtil, a cor é o elo entre o processo da comunicação e da difusão de conceitos e idéias.

\begin{abstract}
"A cor é um fenômeno físico, não tem vida própria; só existe cor se houver luz. Os conhecimentos advindos da física demonstram que a luz é incolor. A cor nada mais é do que a sensação, não é matéria, não existe por si mesma, somente se torna cor quando passa através do estruturado espectro visual. É preciso a interação de quatro elementos para que a sensação da cor seja causada: fonte de luz, objetos coloridos, os olhos e o cérebro de um observador humano. Portanto, a cor existe a partir do indivíduo que a percebe, do objeto que a reflete e da presença da luz. "2
\end{abstract}

A cor é a fonte primária da vida e saúde. Cor é uma "língua" que as nossas células entendem, que se comunicam entre si. O poeta e pesquisador Johann Wolfgang Von Goethe tinha a mesma opinião. Ele considerava a sua teoria sobre a qualidade e as propriedades das cores "Filhas da Luz" a sua obra mais importante e afirmou o que hoje é aceito cientificamente, que existem somente três cores básicas vermelho, amarelo e azul - das quais todas as outras se originam.

"A cor não tem existência material. Ela é tão somente, uma sensação provocada pela ação da luz sobre o órgão da visão". Na mesma obra o autor tece em "A beleza do colorido", a sua concepção sobre harmonia na composição cromática. Considera as belas combinações como meta da harmonia a ser atingida. Destarte, a principal dificuldade está na alteração da aparência que as cores sofrem em presença uma 
das outras. Propõe um processo de harmonização a partir de pares de cortes, sendo que estas devem ser ajustadas, segundo o artista, de modo a formar acordes consoantes ou dissonantes, referindo-se às convergências e divergências cromáticas. Assim, a harmonia dos tons está condicionada a um justo equilíbrio de valores. Dessa forma, mesmo numa escala de tons, esses valores próprios de cada cor se manifestam. E quanto mais ampla for essa escala que poderá ir do preto ao branco, maior será seu impacto. Já a combinação de cores denomina-se a propriedade que têm certos pares de cores de formar acorde - cores que se ajustam umas às outras, em duplas. ${ }^{3}$

\footnotetext{
"A cor é um argumento quase inesgotável, e pode se estudada sob muitos pontos de vista. Para os objetivos que nos propusemos alcançar, trataremos a cor de um ponto de vista, parcialmente, mas significativo para conhecer a fenomenologia da cor, dos próprios valores, inerentes à cor, isto é, da cor apenas como cor." 4
}

O autor nos leva as duas grandes teorias da cor, nelas vamos encontrar a teoria de Newton e a teoria de Goethe, sendo que a cor é vista como combinação de suas essências ou sinais cromáticos e de suas possíveis extensões na análise cromática. Newton nos fala da cor como sintagma do estudo, isto é, das relações entre as cores unitárias (as cores primárias), enquanto que Goethe nos diz que a cor toma vida diante de suas relações, harmonia e diante dos contrastes cromáticos e, portanto vê a cor como mensagem.

Einstein e Infeld defenderam a seguinte teoria: A cor, como o movimento, apresentou-se sempre sob a forma de um "enigma da cor".

Segundo Marcolli, na física, substancialmente o problema da cor depende do problema da luz. A ótica é o ramo da ciência física que estuda a natureza da luz. Historicamente se atinge o conhecimento da natureza da luz através do estudo de sua expansão. Através desta teoria, Erone e Tolomeu conceituaram o problema físico da ótica ligado como problema psico-fisiológico da visão.

Contudo, a discussão até então moderna do problema da luz na ciência física nos remeteu ao conceito imposto pelo cientista italiano Galileu Galilei (1564-1642) que em seu tratado vem nos falar a respeito de Duas Novas Ciências (1638) nos 
relatando que o conhecimento da natureza da luz era dependente do seu movimento.

Galileu Galilei, em seus estudos sobre a velocidade da luz, num diálogo entre o mestre e os discípulos em seu tratado, relata que a velocidade da luz é quase instantânea para o olho, enquanto a velocidade de um som que provém da mesma fonte de emissão (temporais, artilharia) é muito mais lenta, já que o som chega ao ouvido depois de um considerável intervalo de tempo.

Já o cientista Isaac Newton (1642 - 1727) em uma real e própria teoria das cores vem nos mostrar que esta teoria se coloca no âmbito da teoria corpuscolar da luz e é baseada no pressuposto de que a luz solar é branca. Entretanto, em 1666, quando se aplicou a separação dos vidros óticos, Newton observou que um raio de luz, que sabemos deslocar-se quando passa através de uma lente plana de vidro, passando através de um prisma, enquanto escuro, decompõe-se em muitos raios retilíneos, de diversos ângulos e de diversas cores; e que estas cores eram aquelas do arco-íris, na mesma ordem: vermelho, laranja, amarelo, verde, azul e violeta, que denominou precisamente as cores do fantasma visível, o fantasma solar.

Segundo Newton, as cores, portanto, não vem gerar, mas elas somente se tornaram visíveis através de suas separações, ou seja, a decomposição de um raio de luz solar através da refração; isto tanto é verdade que possam novamente ser remexidos, recompondo a mesma cor inicial, o seu conjunto, a luz branca. Portanto, Newton em seus estudos científicos chegou à conclusão que a cor era constituída por substâncias e que a luz era uma mistura de diversas substâncias, mas seu Tratado Optiks: or a treatise of the reflections, refractions, infections and colours of light, surgiu muito tarde e naquele momento já havia muitas oposições por parte de Hooke, mas, sobretudo da parte de Huygens.

Dentro do processo de pesquisa de Newton foram notados aspectos teóricos notáveis, entre eles, o arco-íris, o telescópio refletor, as lentes em vidro crow, flint e os chamados "anéis de Newton" como resultado da interferência (das anotações de Young) entre dois fachos luminosos refletidos por duas superfícies de vidro colocadas em distâncias variáveis. Mas muito permanecia inexplicável. 
Einstein, durante este caminhar, observou mais tarde, ao explicar um raio de luz branca formado por corpúsculos de materiais diversos que todos continuam na mesma velocidade. A partir da teoria corpuscular de Newton, nasce outra teoria da luz, aquela ondulatória do então cientista holandês Christiaan Huygens (1629-1695) que fora explicada em seu "Traité de la lumiére" de 1650. Neste, era retratado o movimento e, como conseqüência, a natureza da luz são tipos diferentes, portanto, chegou-se a conclusão que a luz se propaga como o som, em ondas: não é uma transferência de energia em uma só substância, o ar. Isto explica o porquê da mesma velocidade.

Segundo Newton, a analogia com o som, já intuída por ele, nos diz que o movimento em todas as direções do espaço é um tipo de propagação que, partindo da origem se transmite de uma partícula à outra formando superfícies esféricas chamadas ondas. Em contrapartida, o cientista Huygens afirmava que a luz não é um movimento corpuscular, uma transmissão da matéria situada entre a origem luminosa e o olho, como acontece com o arremesso de uma pedra ou de uma flecha no ar, mas um movimento ondulatório, uma transmissão energética de uma partícula para outra, como acontece com uma pedra quando cai na água.

A modificação da linguagem entre a teoria corpuscular e a teoria ondulatória é substancial.

- Na primeira teoria, os corpúsculos que fazem parte das diversas cores são formados por materiais diversos que tem a mesma velocidade no vazio e velocidades diversas no vidro.

- Na segunda teoria, os raios que possuem cores diversas, são formados por ondas longas e diferentes que tem a mesma velocidade no ar e diversas velocidades no vidro.

- Além disso, para a primeira teoria, a luz branca é formada por uma mistura de diversos corpúsculos que configuram em diversas cores, separáveis no espectro.

- Contudo, já na segunda teoria a luz branca é formada por uma composição de diversas ondas longas que assumem as diferentes cores separáveis no espectro. 
A teoria da física de Newton foi amplamente discutida no século XVII e ainda prevaleceu por todo o século XVIII, ainda que se tivesse que chegar ao século XIX para ver o declínio da teoria corpuscular e o triunfo da teoria ondulatória de Huygens.

Muito tempo se passou para que a misteriosa essência de Huygens fosse atirada pela janela, como o cientista Einstein sugeriu que se fizesse. No entanto, o triunfo da teoria ondulatória reduzia de imediato da cor para a luz e triunfava também neste aspecto a ideologia positivista.

O físico inglês Thomas Young (1773 - 1825) em seus estudos publicados no ano de 1800 , no artigo intitulado "Outlines of experiments and inquiries respecting sound and light", interpretava os "anéis de Newton" como fenômeno da interferência e confirmou definitivamente a teoria ondulatória com respeito à teoria corpuscular; teoria esta que já tinha sido imaginada por um contemporâneo de Young, o francês Augustin Jean Fresnel (1788 - 1827). Entretanto, os estudos sobre a polarização da luz já havia sido experimentado com alguns tipos de minerais da Islândia, um cristal de um mineral transparente, pelo filósofo dinamarquês Erasmo Bartholim em 1699.

Mas quem realmente definiu o estudo foi o físico francês Étreme-Louis Malus (1775 - 1812), estes fundamentos trouxeram uma nova unificação das duas teorias, conforme segue:

- As idéias de Huygens e as de Newton foram precisamente unificadas em um único equilíbrio teórico. Isto porque a descoberta da natureza transversal dos raios ou vibrações luminosas em relação à direção de propagação da luz fez supor o ar não mais como de um gás rarefeito do qual não se conhecia a substância, mas como um corpo sólido. Portanto, se o ar é sólido, então, como podem se mover nos seus próprios corpos?

- Albert Einstein, do ponto da epistemologia declarou ser necessário "jogar o ar pela janela das aulas de física."

- Enquanto Young e Fresnel acreditavam que a luz deveria ser constituída por ondas mecânicas em um ar semi dirigido e material, tornou-se então com o físico escocês James Clark Maxwell (1831-1879) uma onda de eletromagnéticos, algo desconhecido, que simplificava enormemente o 
trabalho do matemático, mas que colocava em maior dificuldade o físico ótico e o experimentador ótico.

A partir de então, as ondas luminosas são eletromagnéticas de pequenas ondas longas, passando assim a teoria da luz a ser considerada como a teoria eletromagnética da luz.

Ainda no século XIX Thomas Young levanta a questão em relação ao problema da tricotomia. O conceito da existência de três cores fundamentais derivava do fato que na seleção da luz realizada por Newton em câmera escura resultavam três cores essenciais, de máxima intensidade.

Então, com a tricromia se estabelece que as cores fundamentais sejam: vermelho, verde e azul, pela mistura das quais se podem obter todas as outras inumeráveis cores. Deste pressuposto nasce a colorimetria, por exigência de produção industrial e do desenvolvimento das novas tecnologias da comunicação ótica. Com isso, se produziam, e se produziriam cada vez mais, novos materiais coloridos.

No processo da colorimetria, as cores distinguem-se segundo três parâmetros:

1. Brilho;

2. Tom;

3. Saturação.

- Por brilho $\rightarrow$ sob o plano descritivo é a clareza de uma cor, se refere a causa física, a intensidade, a um efeito perceptível, a luminosidade. A intensidade é o índice de energia física presente na luz, que pode ser medido pela eletricidade gerada na fotocélula de um fotômetro. Portanto, aumentando a intensidade, aumenta a luminosidade, no sentido que um ponto de energia luminosa nos parece mais brilhante, mais claro.

- Por Tom $\rightarrow$ de uma cor, sob o plano da causa física, nos referimos à extensão da onda, e sob o plano do efeito psicológico nos referimos a tonalidades. No processo do tom, os físicos chegaram à conclusão que além da luz visível, da parte violeta, haverá os raios ultravioletas; 
da parte do vermelho, o campo do infravermelho e ainda as ondas ultra curtas, as ondas curtas, as ondas médias e as ondas longas.

O campo do ultravioleta e do infravermelho é denominado calorifici, sendo invisíveis, variando, portanto, a extensão da onda da luz visível, variando a tonalidade do ponto luminoso passando do vermelho ao laranja, ao amarelo, ao verde, ao azul, ao índigo, ao violeta.

- Por Saturação $\rightarrow$ a saturação das cores é introduzida para indicar a cor pura. Neste caso a causa física é a pureza da cor: o efeito perceptível é a sua saturação. A pureza de uma luz refere-se ao grau de predominância de uma extensão da onda na qual a luz é descomposta pelo prisma. Com a luz de uma única extensão de onda, a cor aparece forte, consistente; com o acréscimo de outras extensões de onda a cor aparece diluída.

Observação: o vermelho puro é consistente, enquanto que o tom rosa ainda que tendo a mesma tonalidade e intensidade do vermelho, aparece diluída.

A seguir, página virtual do programa Tex Design, amplamente utilizado na área de estamparia têxtil. 


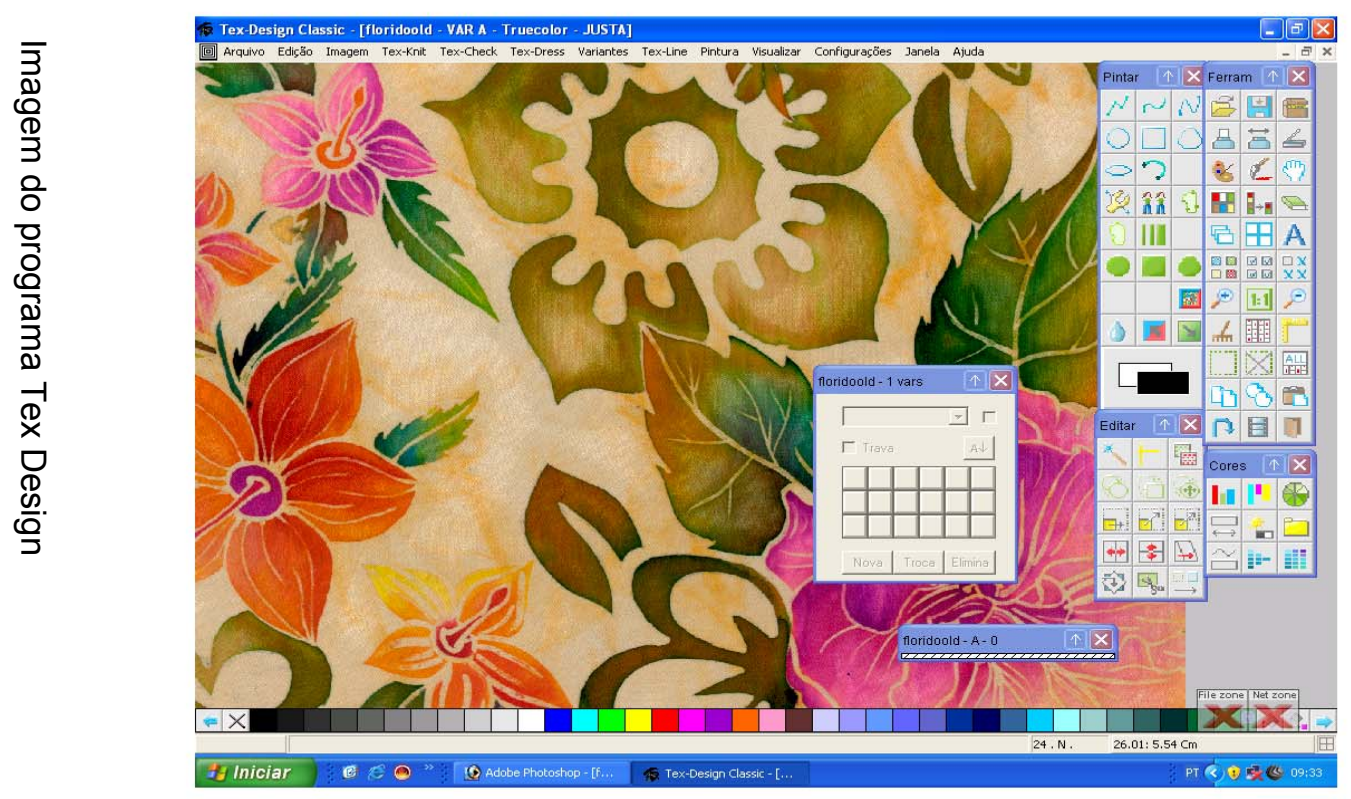

No processo da colorimetria a definição contribuiu para a elaboração dos sistemas das cores, que veremos mais adiante.

Em 1878, o fisiólogo Ewald Hering em seu "Zur Lehre Vom Lischtsinne" que fora editado em Viena, apresenta uma nova conceituação $\rightarrow$ pela percepção, as tonalidades primárias são quatro e propôs a quadricomia em um diagrama circular com o verde e o vermelho colocados aos extremos de um eixo; o amarelo e o azul nos extremos do eixo perpendicular ao precedente, com desenho em forma de lua e compenetração gradual equivalente à composição das cores.

No ano de 1955, os psicólogos L. Hurvich e D. Jameson apresentaram uma nova teoria das cores antagônicas sobre a proposta de Hering. Afirmavam a existência das quatro cores fundamentais com os seus correspondentes processos receptores do olho, sempre no âmbito do processo de estímulo-resposta acoplados, porém em dois grupos, sendo a dupla amarelo-azul e a dupla vermelho- verde. 
David Katz (Kassel 1884 - Estocolmo 1953) vai além dos fundamentos que foram pesquisados no campo da percepção da cor. Em seu estudo The World of Colour, editado em Londres no ano de 1935 faz referência à psicologia da forma. O autor nos fala sobre a variação da mesma cor modificando o fundo colorido ou as aproximações com outras cores (denominada por Itten) teoria expressionista das cores, dado o interesse por este problema, pelos então pintores impressionistas. Percebeu-se que do ponto de vista físico os objetos são incolores, mas possuem uma estrutura molecular (química), ou seja, uma pigmentação material semelhante para absorver e repelir determinadas ondas luminosas da luz branca ou solar.

Sendo assim, o corpo que reflete todos os raios da luz branca aparece branco enquanto que o corpo que absorve todos os raios aparece preto. No caso de um corpo aparecer verde é porque reflete os raios verdes e absorve os outros. Se um raio de luz é laranja não existem ondas que dão o azul e que podem então ser refletidos. Como conseqüência, quanto mais o ar varia da fonte luminosa, tanto mais varia a coloração dos corpos iluminados. Sobre este problema se baseia, sobretudo o estudo das sombras coloridas, que foram desde o final dos anos 400, a grande intuição artística e científica de Leonardo da Vinci; verdadeiramente cada luz colorida produz uma sombra da cor complementar a essa cor.

Faz-se necessário enfatizar que a Teoria das Cores de Leonardo da Vinci, são as formulações históricas contidas em seus escritos e reunidas no livro Tratado da Pintura e da paisagem - Sombra e Luz, cuja primeira edição só foi publicada 132 anos após sua morte. A publicação trata das anotações recolhidas pelo artista ao longo de anos de observação e é a teoria mais corrente, sendo um legado do Renascimento para as artes visuais.

A colorimetria, uma convenção aceita internacionalmente sobre o plano tecnológico, com o pressuposto, porém, de que a cor na realidade não é medida, tratando-se de uma sensação eminentemente individual, além de um suposto "olho normal" diferente de observador para observador.

Assim, inferimos que o procedimento de atuação de todas as cores utilizadas no desenho gráfico, desde estampas dos tecidos a projeções luminosas da 
comunicação visual, das películas diapositivas foto e cinematográficas, pelas insígnias luminosas do vídeo, através da tricromia de base, é dado sobre o plano operativo por duas sínteses - aditivas e substrativas.

A Síntese Aditiva é obtida através da projeção de três fontes luminosas separadas, colorida com uma das três cores fundamentais tricromia: vermelho, verde, azul. Sobre a tela o protetor preto se vê as três cores fundamentais; portanto, por supraposição com rotação se vêem as duplas das cores binárias

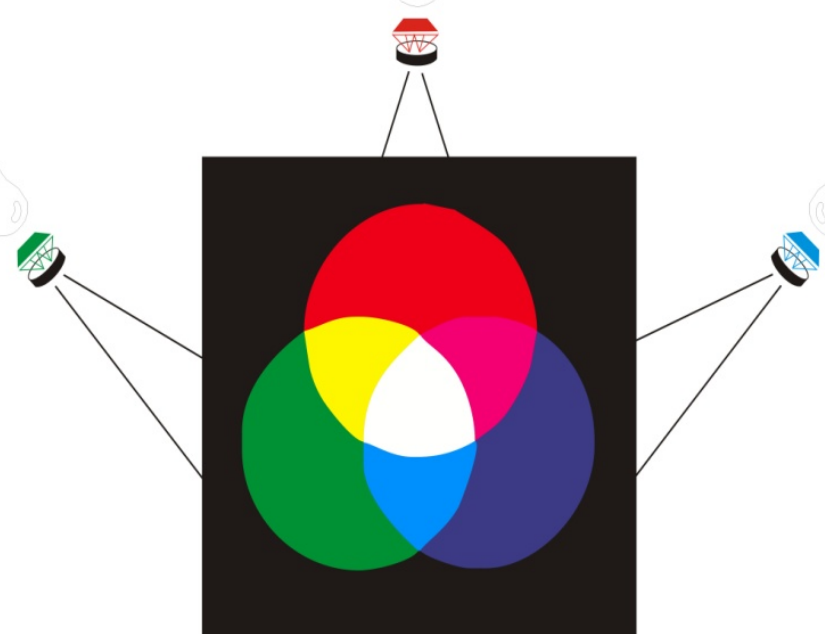
derivadas: o amarelo derivado do vermelho e verde, o centaurea azul derivado do verde e azul e magenta derivado do azul e vermelho. Uma ulterior supraposição com rotação dá as cores temárias e assim por diante. A supraposição das cores dá a luz branca. Sobre a tela, o preto é percebido onde nenhum projeto envia a luz.

A Síntese Substrativa é obtida através da projeção de uma só fonte luminosa branca, colocando entre a fonte e a tela branca dos filtros coloridos. Nesta síntese as cores dos três filtros usados são: amarelo e magenta, o verde dos filtros amarelo e centáurea, o azul dos filtros centáurea e magenta. É o procedimento inverso, portanto, da síntese aditiva. Se todos os filtros são superpostos à luz branca, toda a luz é absorvida, tirada, e se tem o preto.

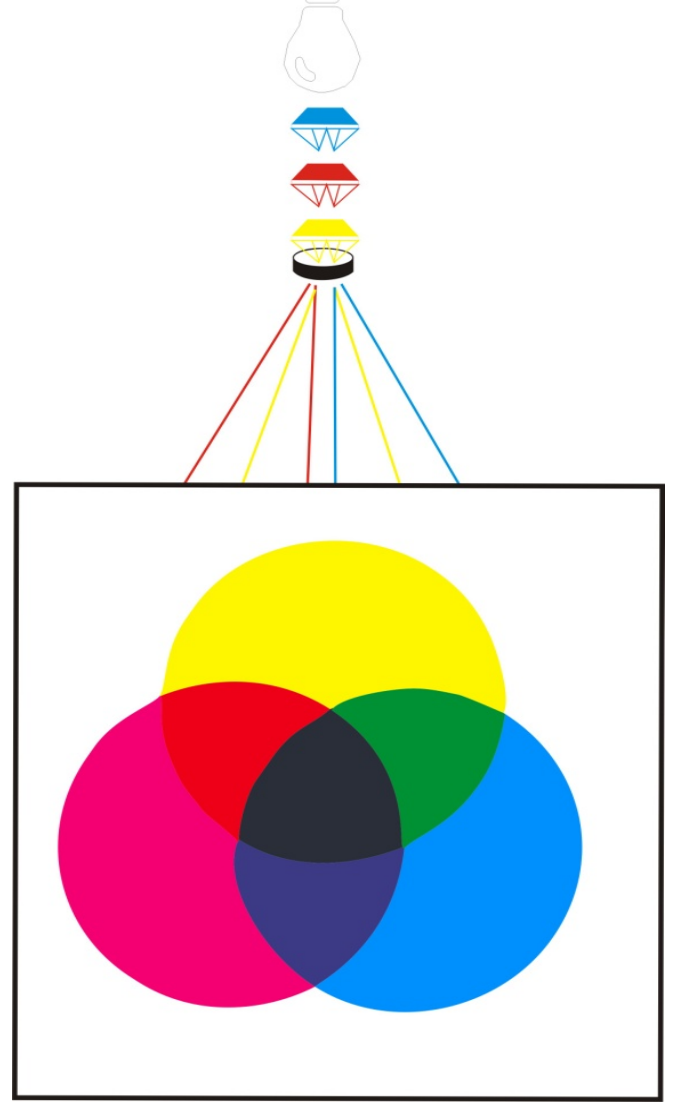


Contudo, a mistura substrativa é mais importante do ponto de vista tecnológico da aditiva, já que é a base de todos os sistemas de impressão e de fotografia a cores. É importante salientar que na impressão a cores o método que triunfou foi aquele da quadricromia, no qual normalmente são usadas como cores fundamentais o vermelho, o amarelo e o azul, enquanto que o preto é usado como equilibrador das tonalidades e revelador das imagens.

Muitos autores insistem em contrapor a teoria das cores de Newton e a teoria das cores de Goethe, criando assim um verdadeiro e próprio dualismo. O querer permanecer neste dualismo assume o significado de querer avalizar a existência de duas verdades, o que é inadmissível sobre o plano científico e do querer contrapor no âmbito da cor a existência de duas culturas, uma científica, física e tecnológica e a outra metafísica, artística - literária, o que é inadmissível sobre o plano teórico operativo.

A teoria de Goethe não teve grande difusão antes do século $X X$, pois ninguém havia prestado atenção ao quanto de profundidade científica vinha elaborada no campo literário. Sua teoria somente aparece um século e meio depois de Newton, cuja teoria, neste longo espaço de tempo acaba sendo amplamente superada.

Então, pode-se dizer que a teoria de Goethe não é uma teoria metafísica para contrapor aquela física de Newton, mas é uma teoria científica que nasce com uma intencionalidade diversa a respeito das teorias científicas contemporâneas.

É importante notar que essas teorias visam a conhecer como se origina a cor da luz, enquanto a teoria de Goethe, ainda que estudasse a cor originada da luz e dando neste campo uma notável contribuição científica, visa a compreender o significado da cor. O caso de Goethe não é único; toda a Literatura Artística (por exemplo Schlosser) evidencia pesquisas deste tipo, que chega até as contribuições do arquiteto Leon Battista Alberti - indo mais além, o qual desde a origem do Renascimento italiano, declarou baseando em suas pesquisas feitas com câmera ótica e pirâmide visual, que existem quatro cores principais: vermelho, azul, verde, amarelo - que ele comparava aos quatro elementos de Empedocle, fogo, ar, água, 
terra, asseverando, porém, contra os cânones aristotélicos, que o branco e o preto não são cores, mas modificações da luz.

A teoria de Goethe, para nós conhecermos a fundo a sua intencionalidade, já pronunciada três séculos antes por Leonardo, que precisou até chegar a Bauhaus de Weimar - Dessau, a nova Escola de Arte e Design fundado por Walter Gropuis; hoje nos chega filtrada através das esplendidas pesquisas sobre as cores de Klee, Kandinsky, Itten, Moholy-Nagy, Albers. Uma notável contribuição para a divulgação desta teoria foi dada pela recente e ótima publicação de Ruppreacht Mathaei, a Goeth's Color Teory editada por Van Nostrand Reinhold, que é um condensado adotado através das profundas interpretações pessoais do curador.

Os estudos sobre as cores de Johann Wollgang Goethe $(1749$ - 1832) datam do período compreendido entre 1790 e 1820, com sua primeira publicação em 18081810, precedida por uma primeira parte sobre os "contributos a ótica" que data de 1791.

A teoria foi subdividida em três partes e desenvolvida em quatro volumes, num total de 925 páginas, na qual se acrescenta a dissertação sobre cores entopitica e os adendos, que requerem mais 209 páginas. Os estudos de Goethe sobre as cores perfazem um total de 2000 páginas e a elaboração de 80 gravuras, no qual se acrescentaram 390 ilustrações contidas no catálogo completo das pinturas e desenhos que se encontram no $5^{\circ}$ Volume.

Contudo, Goethe contribuiu de modo decisivo para a configuração desse tratado da grande paixão científica e experimental, e do profundo dote visual do mesmo. Em sua vida houve três momentos decisivos e fundamentais:

1. A viagem à Itália iniciada em setembro de 1888. Em sua volta a Weimar, em um espírito completamente diferente ele escreveu a Vom Stein: "aumentam as minhas virtudes, mas diminui a minha virtude"; a profunda amizade com Johann Cristoph Friedrich Von Schiller (1759 - 1805)

2. A (correspondência Goethe-Schiller, editada por Einaudi em 1946, mantido em arquivo por Max Hecker que vai de 1794 a 1805, ano da morte de Schiller) 
3. E a correspondência que Goethe teve com Arthur Schopenhauer (17881860) observa-se que Schopenhauer foi ainda mais radical que Goethe na contraposição à pressão positivista na ciência

O anterior antecedente das cores complementares foi elaborado por Jean Henri Hassenfratz (1753 - 1827), um físico numerologista contemporâneo de Goethe, que publicou em Paris (1782) as suas Observations sur lês ombres colorées, primeiro tratado do fenômeno das sombras coloridas.

Chega-se então a concluir que os olhos não vêem as formas, mas somente suas diferenciações através da luz e da sombra, ou através da cor, na graduação. O prazer das cores, presos individualmente ou em harmonia, é experimentado pelo olho como órgão, e pelo olho é comunicado a todo homem: enquanto o prazer da forma pertence ao homem, é comunicado pelo interior do olho.

Interessante é sabermos que o olho é o último, é o mais alto resultado da luz sobre o corpo orgânico, é uma criação da luz. E neste processo, o ouvido é surdo, a boca é muda, enquanto que o olho percebe e fala.

Também se observou que a percepção da cor, é, portanto, o que nos permite conhecer as formas, construir a estruturalidade da cor, de até chegar à representação da espacialidade cromática e da luz. Newton derivou o espectro das cores provindas da câmera escura; Goethe quis conhecer o espectro e a realidade das cores no claro, à luz do dia.

Goethe, em sua análise espectrográfica completada com rigor científico demonstrou que existem somente três cores que chegam ao máximo de intensidade e saturação. Estas três cores, portanto, primárias pela percepção visual são: o vermelho de Goethe, o amarelo e o azul; todas as outras cores delas derivadas, Goethe chamou o seu vermelho púrpura. Sucessivamente, na época Bauhaus, estas cores foram precisadas como vermelho carmim, o amarelo cádmio, o azul cobalto.

Por certo período, foram feitas análises sobre os raios através de dois prismas cruzados, Goethe percebeu que também as cores de Newton eram reproduzidas nas mesmas condições da câmera escura, sendo três: o laranja (que Goethe quis 
chamar amarelo vermelho, o verde e o violeta). Portanto, a tricromia de Goethe $\left(\mathrm{G}^{1}\right.$, $\left.\mathrm{G}^{2}, \mathrm{G}^{3}\right)$ e a tricromia de Newton $\left(\mathrm{N}^{1}, \mathrm{~N}^{2}, \mathrm{~N}^{3}\right)$ agora melhor definidas nos nomes, constituem o verdadeiro espectograma configurável em um hexagrama.

No ano de 1832, Goethe elabora o disco cromático dos adendos, visualizando no cinza o equilíbrio cromático dos complementares. Foram então reproduzidas com retângulos adjacentes as três cores de Newton (verde, violeta, laranja) sob fundo cinza escuro e as três cores de Goethe (vermelho, amarelo, azul) sob fundo cinza claro.

Schiller contribuiu para algumas explicações no que diz respeito à complementaridade e dualidade das cores e a relativa explicação estrutural. Por meio de pura percepção e um rigoroso trabalho científico experimental, Goethe chegou a resultados notáveis, no qual prevaleceu o princípio da dualidade com base fundamental na visão. Ele percebeu, por exemplo, que uma mistura aditiva de duas cores newtonianas (laranja e vermelho) dão uma cor goethiana (amarelo) e viceversa, uma mistura substrativa de duas cores goethianas (amarelo e azul) dão uma cor newtoniana (o verde). O que demonstrava, portanto, a complementaridade de Hassenfratz, e o deslocamento das cores por simetria no disco cromático, mas com um alívio diferente, com respeito, por exemplo, ao sistema Ostwald.

Conclui-se, portanto que o triângulo é a estrutura base da cor, da qual provém o hexagrama (dois) triângulos eqüiláteros superpostos, com vértices opostas e, portanto, o anel cromático. O significado é deduzido pelas caracterizações dos complementares.

Então:

- A dupla amarelo-violeta é a dupla clara escura, o contraste diurno típico das cores fotos;

- A dupla vermelho-verde - intensificação das cores cromáticas;

- A dupla laranja-azul é do quente-frio, das cores térmicas.

O sistema de Ostwald não foram desideráveis eqüidistantes, enquanto a teoria de Goethe dava interessantíssima subdivisão complementar e derivada, secundária e terciária, em relação a cores. Diante dos fatos, muitos estudos ocorreram e sob a confirmação dos estudos feitos, observa-se que: 
- O primeiro grande contraste das cores, de amarelo-azul, de polaridade perceptiva;

- O segundo contraste, de grandiosidade, pelo amarelo-laranja e pelo azulvioleta até o alto e até o baixo;

- E assim se chega ao terceiro contraste entre o mais alto e o mais baixo, ou seja, entre o vermelho (o vermelho saturno) e o verde (azul-verde ou óxido de manganês).

Goethe, pelo caminho dos contrastes e da luminosidade, configurou uma escala cromática que define a extensão do campo em relação à luminosidade de cada cor. Assumindo o branco igual a 10 (máxima intensidade luminosa) e o preto igual a 0 (zero), determinou os seguintes valores numéricos, na ordem de amarelo, laranja, vermelho, violeta, azul, verde, $9 \div 8 \div 6 \div 3 \div 4 \div 6$, onde as dimensões de fundo da imagem invertem as proporções luminosas a fim de que as cores apareçam com a mesma luminosidade, pelo qual a sucessão de amarelo, laranja, vermelho, violeta, azul, verde são nas proporções de 3:4: 6:9: 8:6.

Depois de Goethe, a cor teve um desenvolvimento fenomenal, articulado em dois momentos sucessivos. O primeiro momento é concentrado sobre a elaboração dos sistemas voltados para a estruturação espacial da cor, que vai do fim do século XVIII até a metade do século XX.

No que diz respeito aos estudos sobre cores, pode-se dizer que a exigência foi por muitos aspectos análoga. A cor é pura luz, todavia existe a materialidade da cor; a cor, além disso, não bidimensional: o tom, o brilho, a saturação nos dizem claramente que existe uma tridimensionalidade da cor, representada na polaridade das cores fundamentais e no movimento de uma cor para outra através da graduação. E isto se reflete também na arte, na pintura, nas pinturas bidimensionais, e em todas as expressões gráficas através da cor. Daí a exigência de geometrizar a cor não com o fim, obviamente, de congelá-la em esquemas abstratos, mas para compreender a fenomenologia.

O segundo momento do desenvolvimento sobre a cor é centrado na elaboração da linguagem da cor. Estes desenvolvimentos são específicos nas recentes pesquisas 
sobre a cor, sendo que parecem delinear as diretrizes a pesquisa já citada de Rupprecht Matthaei, edição alemã de 1970 intitulada Goethe Farbenlehre, e a edição americana de 1971 intitulada Goethe's Color Theory, com reedição em 1971 do formato pocket, (1 ${ }^{a}$ edição americana de 1963) da pesquisa de Josef Alberes intitulada Interaction of Color.

Assim, a pesquisa de Matthaei procura evidenciar a pura fenomenologia da cor; fisiológico e físico. Os argumentos importantes da fenomenologia fisiológica são:

- $\quad$ Os efeitos da luz e do escuro sobre o olho;

- $\quad$ Os efeitos dos objetos brancos e pretos sobre o olho;

- $\quad$ As superfícies cinza e as imagens;

- $\quad$ As colorações luminosas de tirar a visão dos objetos;

- As imagens coloridas;

- As sombras coloridas;

- $\quad$ As luzes fracas;

- $\quad$ Os contornos subjetivos (com apêndice sobre cores patológicas);

- $\quad$ As cores dioptricas (cores produzidas por um meio colorido, que ativa sobre o olho ou sobre uma superfície, através dos dioptricos produzidos, o efeito de luz e sombra) de primeira e segunda classe (os de segundos desunidos pela refração);

- A refração sem a aparição da cor; a derivação de fenômenos induzidos, sugeridos;

- O acromatismo e o hipercromatismo: o benefício dos experimentos subjetivos como transição ao objetivo;

- $\quad$ As condições para o surgimento da cor;

- $\quad$ As condições para o crescimento da cor;

- A combinação de experiementos subjetivos e objetivos: as cores catoptricas, paropticas e epopticas;

- $\quad$ As cores entopticas descobertas pelos físicos franceses Mauis, Biot e Arago em 1809, através de reflexos e dupla refração e o fenômeno da polaridade

Notemos que os argumentos importantes da fenomenologia física são: 
- Os contrastes químicos;

- $\quad$ O branco e o preto;

- A indução da cor;

- A intensificação;

- O ponto culminante;

- A estabilização;

- $\quad$ O atravessamento do espectro;

- A reversibilidade;

- As misturas reais e aparentes e a extração.

Observemos também os estudos sobre a cor de Albers, um professor da Bauhaus, que conduziu seu ensinamento nos Estados Unidos, a fundação da linguagem da cor através uma pesquisa eminentemente experimental. A referência é sempre a teoria das cores de Goethe, e a pesquisa de Albers se articula sobre os seguintes pontos importantes:

- $\quad$ Capacidade de lembrar ou memorizar a cor - memória visual;

- Leitura da cor no seu contexto e textura; porque o papel colorido - no lugar de pigmentos ou pinturas; uma cor tem mais de um aspecto - a relatividade da cor;

- Luminosa ou escura-intensidade da luz, brilho (estudos sobre a graduação - novas apresentações; intensidade da cor - a clareza);

- Uma cor aparece como duas cores - aparecer fundo de resíduos; duas cores diferentes aparecem iguais - subtração da cor; porque o engano da cor? - pois imagine contraste, mistura duas cores, sobre o papel - ilusão de transparência;

- Misturas factuais - aditiva e substrativa transparência e ilusão espacial, limites das cores e ação plástica;

- $\quad$ Mistura ótica - pós-imagem e revista e corrigida, feito Bezold - por Wilheim com Bezold, (1837-1907);

- Intervalos das cores e transformação: ainda a mistura média intercedendo as cores: a justa posição das cores - harmonia quantidade (referência à escala de Goethe); 
- $\quad$ Filme a cores e volume a cores - dois efeitos naturais, estudos livres um desafio à imagem - faixas justa posição restrita.

Os professores da cor - instrumentação da cor; a lei Weber - Fechener - a medida na mistura, o estímulo físico e o efeito psicológico da cor, e aquilo que é efetivamente percebido, da temperatura da cor à umidade na cor; limites vibrantes contornos reforçados: a luz de igual intensidade - limites evanescentes - as teorias e os sistemas da cor; o ensinamento da cor - glossário, variações em direção à variedade.

Em 1969, com segunda edição em 1973 é publicada, porém, a Theoria der Farbe di Johannes Pawik, que resulta em um bom compêndio, mas ainda muito incompleto, das várias pesquisas teóricas com caráter didático.

Em 1974, com um ótimo ensaio produtivo de Johannes Pawik, sai a Goethefarbenlehre, que é uma válida possibilidade de verificação dos estudos contemporâneos sobre a cor.

Ocorreu que também em 1974, o primeiro livro dedicado à linguagem da cor, o Farbe als Sprache de Hans Joachim Albrecht não é do tipo teórico-experimental, mas aplicado, destituído de procedimentos artísticos. É na verdade baseado sobre uma trilogia artística, Robert Delauny, Josef Albers, Richard Paul Lohse, para subir novamente por esta a conceitos gerais.

Ocorreu então um enquadramento em discurso sobre a linguagem da arquitetura, no The Language of Architecture di Sven Hesselgren , em 1972, que dá a medida do alto nível trazido pela Escola sueca nas pesquisas sobre visão. São transmitidas muitas pesquisas experimentais de Balinki, Bragg, Härd, Brochmann, Knudsen e Harris, Katona, Johansson, entre outros, que denotam o ótimo nível de informação entre uns e outros. Portanto, o sentido das pesquisas experimentais modernas que se partem em forma de leque com diferentes orientações se dá nos processos do desvio de uma cor para outra cor. 
Rudolf Arnheim, no capítulo sobre a cor de seu livro Art and Visual perception de 1954 editado na Itália em 1962, tinha intuído este fenômeno baseado na linguagem da cor. Não são as cores principais, observava Arnheim, mas o breve desvio delas para determinar o efeito. O equilíbrio entre duas cores nas misturas é muito instável, de maneira que o predomínio de uma cor é na influência exercida por outras cores que se encontram imediatamente próximas. O fenômeno de igualdade e do contraste acentua e valoriza uma cor em detrimento de outra, e por outro lado torna estável a mistura e define sua temperatura. Não é, portanto, a tonalidade dominante, e às vezes nem a clareza e a saturação, mas provavelmente são as modificações a determinar a quantidade expressiva das cores. A temperatura das cores como fato expressivo e fundamental é uma qualidade acentuada pela impureza.

3.1.1 O processo fisiológico: o olho

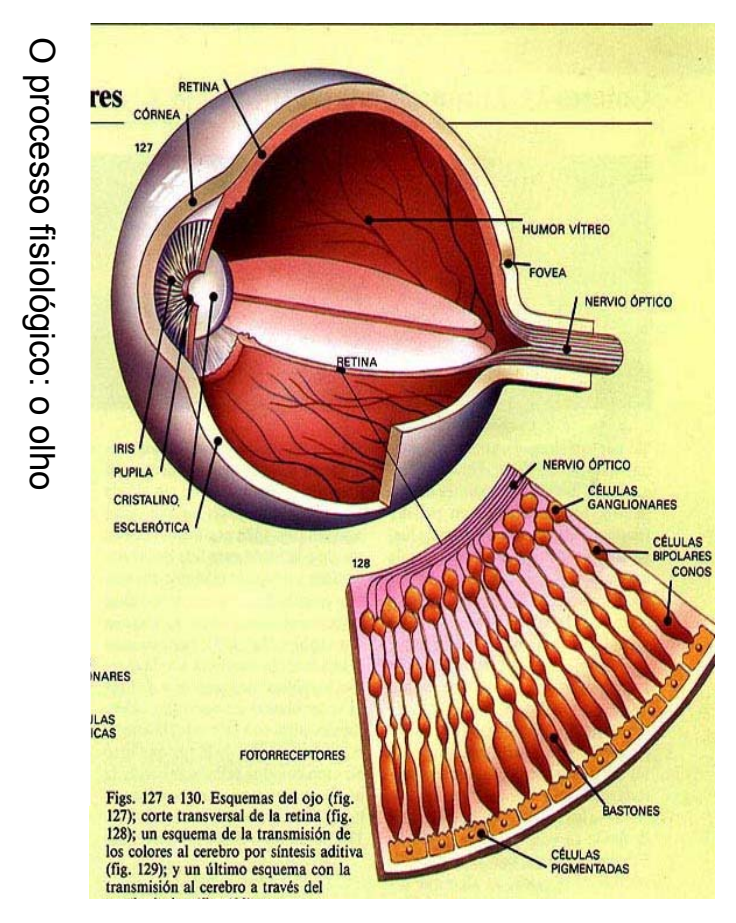

O estímulo luminoso penetra os olhos até chegar à retina, onde os receptores absorvem uma porção de luz incidente, gerando sinais que eventualmente serão interpretados pelo cérebro. Em muitos aspectos a formação da imagem é similar ao processo da câmera fotográfica.

Segundo Berns (2000), a qualidade da imagem retinal depende do nível de absorção e das propriedades focais da córnea, das lentes, dos fluídos do globo ocular (humor aquoso e humor vítreo). Esses elementos ópticos, mostrados na figura acima, influenciam as propriedade espectrais e espaciais dos receptores de luz.

\subsection{Formas}


Os conceitos de forma e cor, quando colocados um ao lado do outro, imediatamente indicam o quanto são diferentes. São dois fenômenos que constantemente nos circundam de variadas formas e sem os quais seria impossível imaginar a vida. Eles são a aparência externa, a cobertura do mundo à nossa volta e nos são necessários. Seria, então, possível comparar a nossa necessidade de forma e cor com uma sensação parecida com a fome ou a sede? Poderia alguém falar de uma fome de forma ou uma sede de cor?

Nós, constantemente, nos alimentamos com o que adquirimos através da nossa percepção. Exatamente como precisamos comer e beber, somos alimentados na nossa vida de sentimentos, entre outras coisas, pelas cores e formas. Em um mundo sem formas, não teríamos onde nos apoiar. Um mundo sem cor nos daria pouca alegria. Na cor vivenciamos algo que se expande e nos liberta da gravidade. A forma tem algo de concreto, nos dá um sentimento de certeza e pode ser experimentada pelo olhar e pelo tato.

Embora haja formas matemáticas, formas desenhadas, formas sociais, sempre se pensa primeiro na forma inserida no espaço. Através do elemento plástico, modelando o barro, talhando a pedra, entalhando a madeira - sentimos mais diretamente o mundo da forma, pela própria atividade e concentração. Trabalhando nessa direção, fizemos imagens que podem ser livres ou direcionadas, abstratas ou figurativas, côncavas ou convexas, verticais ou horizontais, grossas ou finas, redondas ou angulosas, relaxadas ou tensas. Sempre trabalhando com as duas mãos, podemos nos expressar através das forças tridimensionais - a matéria se ergue da gravidade.

Caos, matéria, substância, ganham pela forma da arte, se humanizam permeados pelo espírito. É como se alguém que estivesse modelando o barro, se tornasse um pouco mais pesado, mais volumoso, atarracado, no vigor da atividade; indo de encontro a terra, agarra-se a ela com as mãos e a mente. Quem modela, pode também dar movimento, estrutura, luz e conceito para a matéria, configurando uma interação entre peso e volume. 
A forma luta pela unidade, ela nos fixa. A cor nos faz soltar nossa própria experiência interior. Entre a forma e a cor existe o movimento: a cor quer respirar no movimento e a forma quer fixá-lo; ambos precisam de movimento. Uma cor, uma forma estática são indigestas, não nos dão uma vívida impressão.

Assim, forma pode ser definida com a figura ou imagem visível do conteúdo. A forma diz respeito à natureza da aparência externa do objeto. Tudo que se vê possui forma. A percepção da forma é o resultado de uma interação entre o objeto físico e o meio de luz agindo como transmissor de informação e as condições e as imagens que prevalecem no sistema nervoso do observador, que é, em parte, determinado pela própria experiência visual.

\subsection{Harmonia e Equilíbrio}

\subsubsection{Harmonia Cromática}

Ao contrário do que muitos pensam, harmonia cromática não é uma escolha aleatória de tons agradáveis ou bonitos. Ocorre quando certa escolha de cores permite ao olho manter-se em equilíbrio, ou seja, a soma de todos os tons tem que resultar em cinza médio.

Quando há harmonia cromática, uma situação de

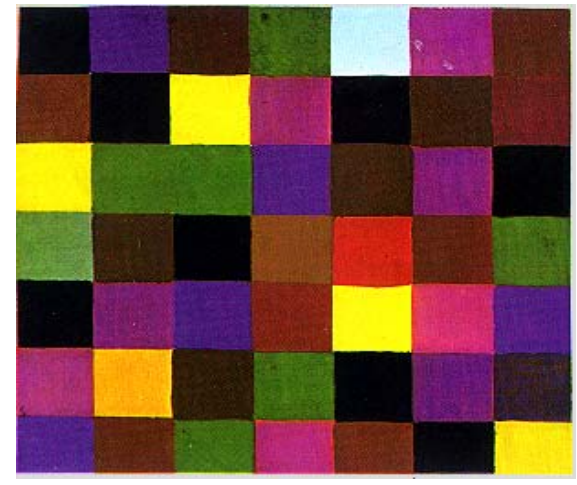
conforto para o olho se desenvolve, uma situação de relaxamento é percebida, o olho dificilmente cansará de olhar a imagem. Essa é a grande vantagem de se trabalhar a partir da harmonia. Embora não haja regras fechadas para se seguir estritamente, há alguns princípios gerais que podem ser aplicados para criar escalas de cores harmoniosas.

A harmonia possui alguns princípios fundamentais. ${ }^{5}$

- Similaridade: em composições, cores semelhantes funcionam bem quando juntas; 
- Familiaridade: consideradas as expectativas do observador;

- Equilíbrio: distribuir as cores segundo seu peso aparente;

- Ordem: qualquer boa escala de cores deve ter uma ordem cuidadosamente planejada que governe não apenas a escolha das cores, mas a colocação destas na composição;

- Ambigüidade: procura-se eliminar todos os elementos de incerteza e de indefinição das composições.

A harmonia cromática, na tradição artística ocidental, expressa o equilíbrio dos elementos de escalas de tons. Assim, buscam-se o equilíbrio entre uma cor dominante, uma cor tônica (que traz contraste) e uma cor intermediária. ${ }^{6}$

- Cor dominante: $\rightarrow$ é aquela que ocupa a maior extensão no conjunto da composição;

- Cor tônica: $\rightarrow$ é a coloração vibrante que, por ação de contraste complementar, dá o tom ao conjunto;

- Cor intermediária: $\rightarrow$ é a coloração que forma a passagem, o meiotermo entre a cor dominante e a cor tônica.

Em certo grau, os princípios da harmonia e do contraste parecem contradizer-se diretamente. Porém, nenhum conjunto de princípios é inerentemente melhor que outro. Quando se constrói uma escala de cores deve-se selecionar e adotar alguns princípios $\mathrm{e}$, invariavelmente precisaremos descartar outros. A harmonia e $\mathrm{o}$ contraste são faces diferentes da mesma moeda - se tiver um, sem o outro, o observador notará que algo está faltando. ${ }^{7}$

\subsubsection{Harmonia Monocromática}

É a mais simples de todas as harmonias. Acontece quando o conjunto de cores de uma composição varia dentro de uma cor com vários tons ou de uma cor conjugada com cores neutras. Como o nome sugere, esta escala emprega uma única cor. $O$ uso de diversas mesclas e nuances da cor produz a variedade. Portanto, uma escala monocromática baseada no vermelho pode incluir o vermelho puro, o 
vermelho tijolo (uma nuance de vermelho), o morango (uma leve mescla de vermelho) e o tom rosa (uma mescla extrema do vermelho).
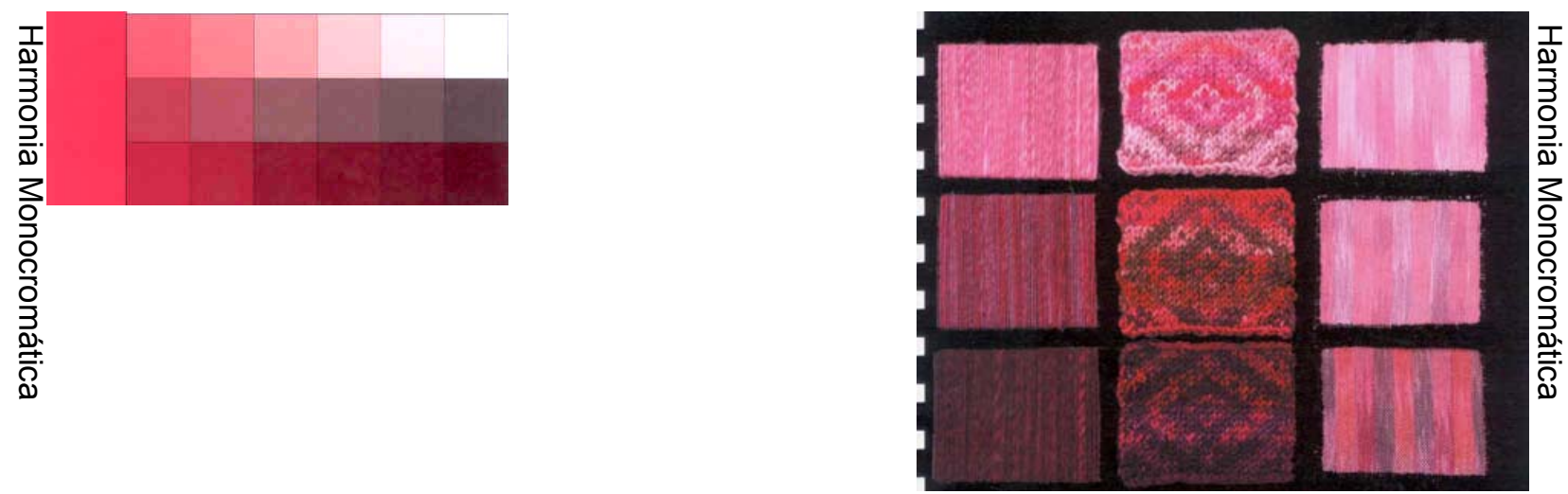

\subsubsection{Harmonia Análoga}

Harmonia que utiliza três cores que se encontram uma ao lado da outra no disco cromático e que basicamente possuem a mesma origem (vermelho, vermelhovioleta e magenta, por exemplo). O incrível número de combinações possíveis torna esta harmonia bem versátil.

Embora seja possível expandir uma harmonia de cores análogas para incluir quatro ou até mesmo cinco cores adjacentes, se isto acontecer, a faixa de cores será tão grande que as cores nos extremos do espectro terão pouca relação umas com as outras, o que tende a diluir o efeito geral de uma escala de cores análogas. Embora harmonias de cores análogas sejam extremamente versáteis, a similaridade das cores tende a deixá-las também harmoniosas. Infelizmente, esta falta de contraste marcante geralmente significa que harmonias de cores análogas criadas de modo pouco elaborado, podem deixar de prender a atenção do observador.
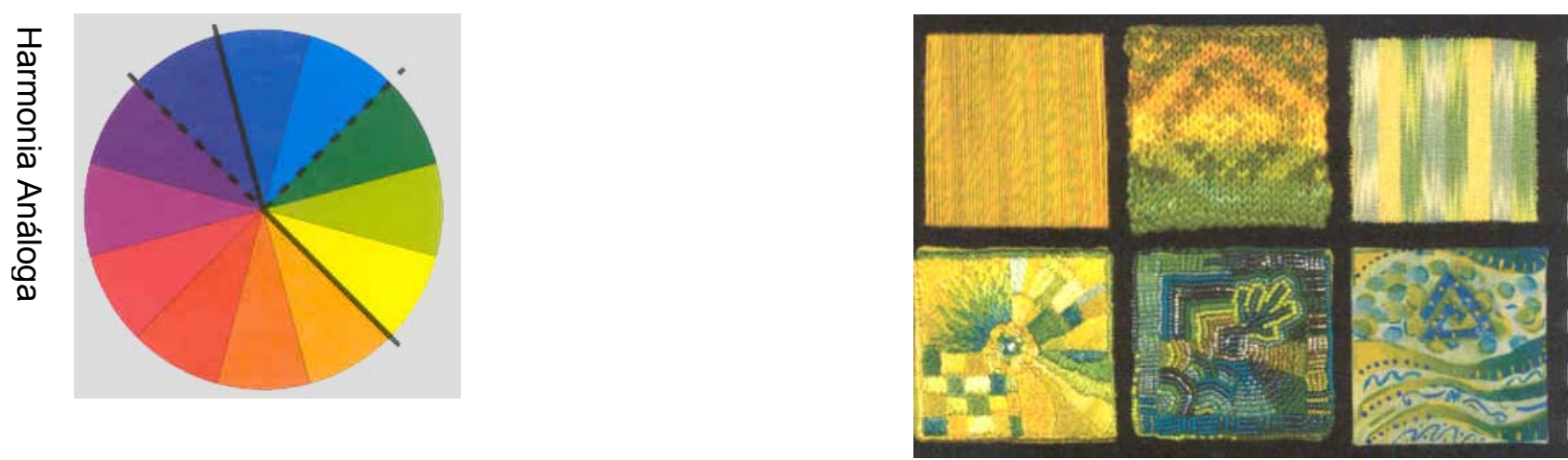


\subsubsection{Harmonia Complementar ou Oposta}

Harmonia em que um dos complementos é quebrado nas duas cores adjacentes a ela. Uma escala de cores complementares vermelho e ciano, por exemplo, pode se transformar em uma escala de cores complementares divididas que usa vermelho, azul claro e verde-mar. As harmonias de cores complementares são extremamente atraentes e vibrantes - em muitos casos, até mesmo mais atraentes que a harmonia que emprega as três cores primárias.
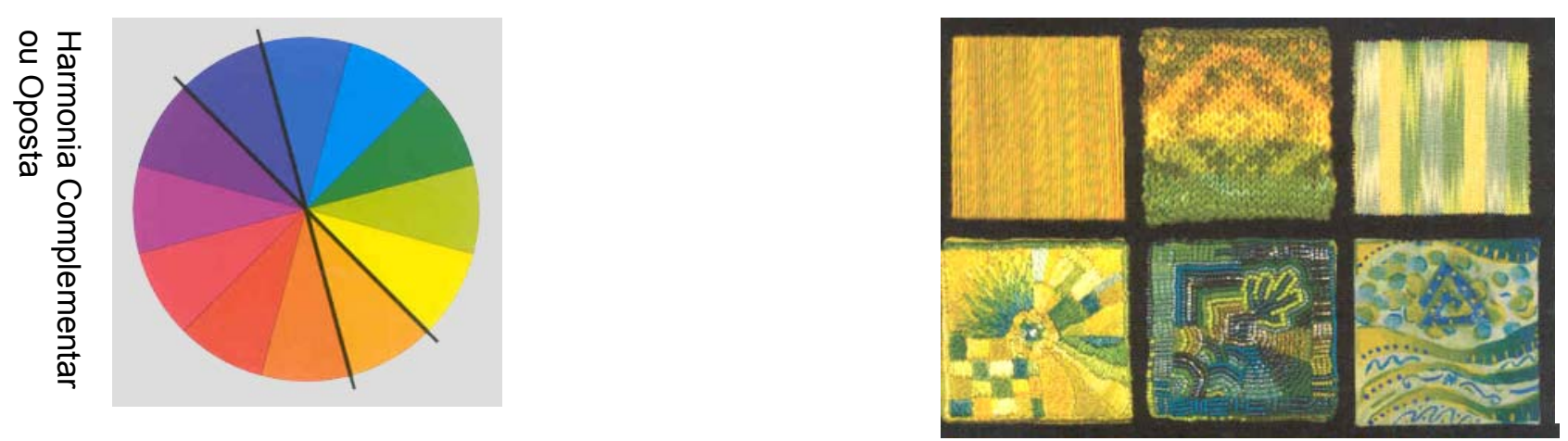

\subsubsection{Harmonia Complementar Dividida}

Esta é uma variação da escala das cores complementares. Aqui um dos complementos é quebrado nas duas cores adjacentes a ele.

A partir de escala de cores complementares vermelho-ciano, por exemplo, pode-se transformar numa escala "complementar duplamente dividida" utilizando-se o vermelho em oposição ao azul claro e ao verde mar. A vantagem é que esta escala possui maior variedade tonal.
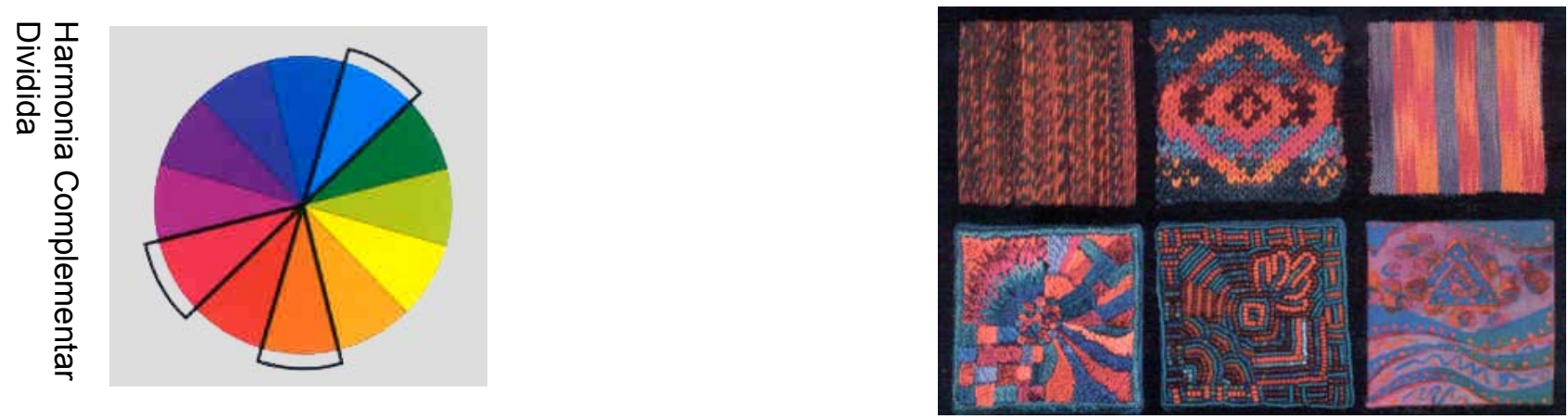


\subsubsection{Harmonia Complementar Duplamente Dividida}

Cores complementares duplamente divididas utilizam as cores adjacentes das duas complementares. Um acentuado contraste, muitas vezes criado por cores complementares, pode ser atenuado pelo uso de harmonia complementar dividida. Também neste exemplo de harmonização, deverá dominar uma das cores do esquema que, em tom mais claro ou acinzentado, será aplicada na maior extensão. A cor seguinte será mais intensa, pois é também neutralizada. A terceira seguirá a mesma ordem, porém a que estiver em menor área aparecerá com a maior intensidade. A vantagem deste tipo de escala é que ela se torna variada. ${ }^{8}$
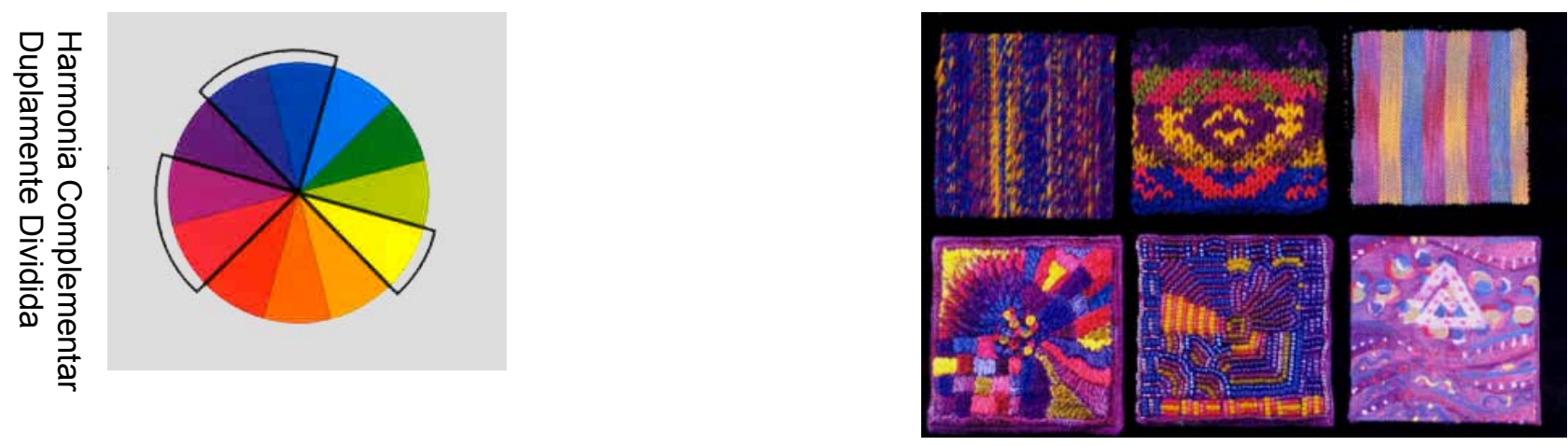

\subsubsection{Harmonias Triplas ou Tríade}

Emprega três cores diferentes que estejam igualmente espaçadas ao longo do disco de cores. A escala mais eficiente deste tipo é a de três escalas primárias, mas pode ser constituída por três cores "secundárias" ou três "terciárias".
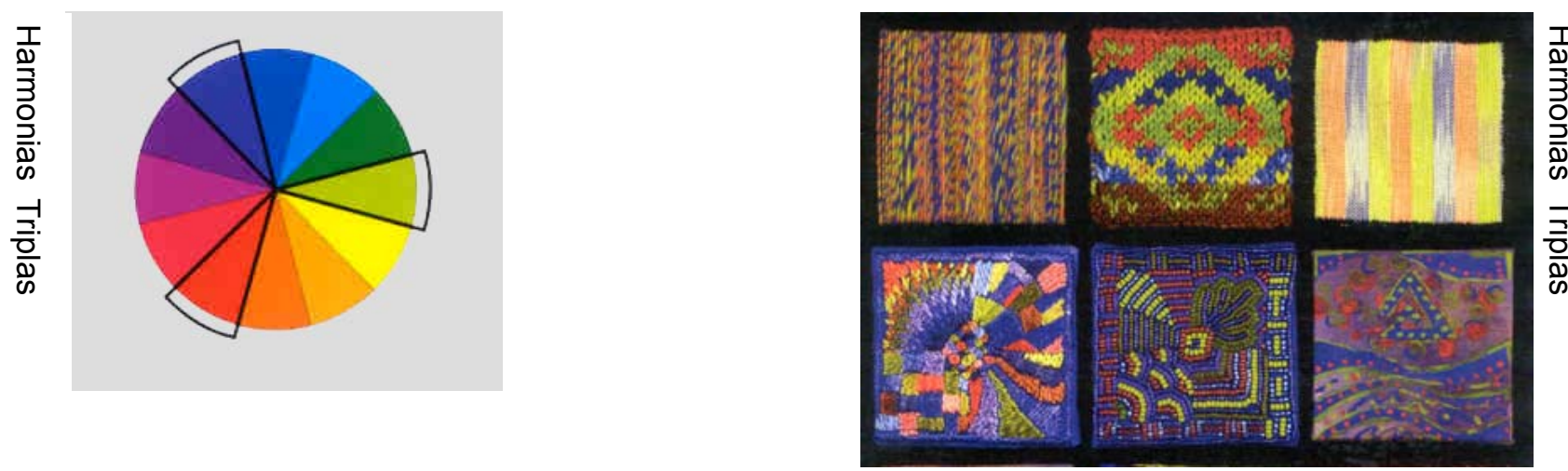

Esses princípios não são rígidos. São orientações disseminadas pela cultura e pela literatura, incluindo textos de cientistas, artistas e filósofos. A aplicação depende sempre de especificações do contexto e dos meios em que deverão ser 
empregados. Guimarães (2001) ressalta a importância da "cor como informação". O autor discorre sobre a cor que colabora no processo de comunicação em diferentes mídias e como, a partir de uma multiplicidade de códigos, a composição cromática pode contribuir no sentido de organizar, dirigir e acrescentar valores à informação textual. Também ressalta que a leitura de um conjunto visual não é sincrônica, como exemplo pode-se citar uma página de jornal onde os títulos, o corpo da matéria e a legenda são lidos de forma diacrônica. No ato de informar e comunicar, a cor pode atuar de forma positiva ou negativa (Guimarães, 2003). Como ações negativas destacam-se: a saturação, a redução, a neutralização, a maquiagem e a camuflagem.

A saturação está ligada ao amplo acesso e popularização da cor. Guimarães (2003) faz uma diferenciação entre uso da cor saturada ou uso saturado da cor, pois a primeira nem sempre implica em exagero. A ação negativa da "redução" refere-se à diminuição do repertório das cores. Ocorre quando uma cor é utilizada repetidas vezes e sua associação a um significado se torna estereotipada. Já a ação negativa da "neutralização" é identificada quando há o mesmo tratamento cromático em informações não relacionadas, gerando interpretações equivocadas. Percebe-se a ação negativa da "omissão/sonegação" quando ocorre a ausência de cor, seja por questões técnicas ou de natureza econômica. A "dissonância" ocorre quando a aplicação de cores é contraditória ou dissonante em relação aos outros elementos da página. A "maquiagem/camuflagem" refere-se à utilização de filtros ou iluminação diferenciada, ou tratamento da edição gráfica na manipulação cromática de imagens. Estes recursos são utilizados no intuito de valorizar, mas, muitas vezes, este efeito cria uma aparência que não corresponde à realidade do objeto em foco, camuflando a informação.

O "falseamento" e a "deformação" são ações negativas que induzem o leitor, intencionalmente ou não, a incorporar os valores em relação ao conjunto verbovisual.

As ações positivas da cor são: antecipação, discriminação, condensação e intensificação Guimarães (2003). 
- A antecipação ocorre quando a cor se antecipa aos outros códigos (no caso de uma revista ou jornal são texto e imagem) e delimita um número de significantes retirados de seu repertório.

- A ação positiva da discriminação/diferenciação é possível quando, a partir da cor podem-se estabelecer diferenças, contribuir para a organização da informação, selecionar e ressaltar parte de todo, criar hierarquias tanto em leitura quanto em importância.

- A condensação e a intensificação se referem à ação da cor, capaz de concentrar em si essência do discurso verbal e gráfico. A intensificação tende a chamar a atenção do leitor para a essência simbólica da cor e para a forma como a composição visual foi trabalhada, com a finalidade de relacionar cor e mensagem.

Para a construção de informações cromáticas, em projetos gráficos comprometidos com a qualidade da informação, Guimarães (2003) recomenda:

- As determinações de quais cores estão associadas à natureza concreta do fato:

- A construção da paleta de cores;

- A obtenção de um sistema simbólico coerente, responsável de alto valor informativo e coerente com as intenções da publicação;

- A adaptação do sistema simbólico aos recursos e limitações do meio ou dos meios em questão.

O autor também propõe um modelo para investigação da cor-informação em produtos na mídia impressa e digital. Este modelo requer:

- Identificação das características técnicas da mídia. Avaliação de quais os recursos disponíveis, quais os utilizados e quais limitações técnicas podem restringir a paleta de cores. Deve-se considerar o tempo de produção, que é diferente em cada mídia, e a qualidade de reprodução e cores; 
- Observação da linha editorial da publicação, a partir da avaliação de outras notícias publicadas; observar se o comportamento pressuposto é eventual e se ocorre com freqüência; a avaliar as ações positivas e negativas das cores;

- A avaliação das cores utilizadas e das suas relações hierárquicas com base no sistema simbólico das cores.

Equilíbrio $\rightarrow$ é um conceito relacionado ao estado de um sistema ou mais sistemas no qual não ocorrem mudanças no total que possam ser observados claramente, ou seja, no qual cada alteração é compensada (ou equilibrada) por outra(s) complementar(es). Do ponto de vista da dinâmica, a resultante de forças deve ser igual a zero. Portanto, se descrevem três métodos para a formação de equilíbrio no acorde de uma dupla de cores. ${ }^{9}$

- Primeiro $\rightarrow$ pela intensificação ou diminuição do tom ou de luminosidade de uma das cores, sem perda de crominância. Exemplo: vermelho e verde (complementares), manter o vermelho e acrescentar ao verde o amarelo (para clarear) ou o azul (para escurecer). Ou, manter o verde e acrescentar ao vermelho o amarelo (para clarear) ou azul (para escurecer);

- Segundo $\rightarrow$ pela dessaturação ou rebaixamento do tom, através da mistura de branco ou preto, havendo perda de crominância nos tons, partindo-se para a combinação de valores. Exemplo: vermelho e verde, manter o vermelho e acrescentar ao verde o branco (para clarear) ou preto (para escurecer). Ou, manter o verde e acrescentar ao vermelho o branco (para clarear) ou o preto (para escurecer);

- Terceiro $\rightarrow$ pela utilização de debrum branco, preto ou cinza, entre o vermelho e o verde. No entanto, deixa de ser um acorde de dois tons, e passa a ser um acorde misto do tom (vermelho e o verde) e de valor (devido ao branco, preto ou cinza). Segundo vários autores, é comum a confusão entre harmonia e combinação ou 
acorde de cores. Para que haja harmonia, é necessária a superação do conflito de forças contrárias, como exemplo anterior, entre o vermelho e o verde, que são cores complementares. "Todas as cores são amigas das vizinhas e amantes das opostas" 10

3.3.8 Harmonia e Equilíbrio
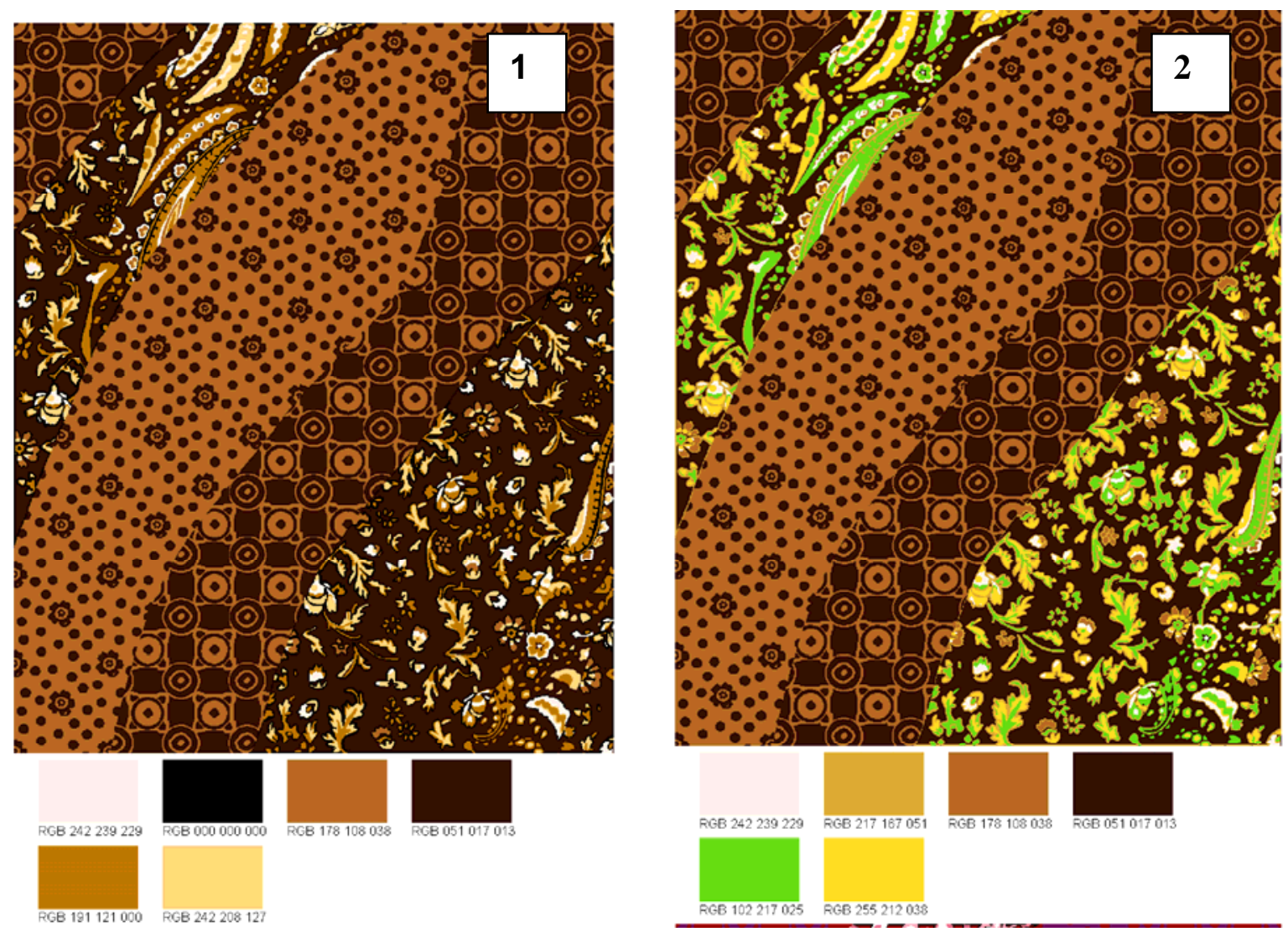

1. Família dos sujos - mexeu com brilho e saturação.

2. Mesmas cores do fundo, sendo que houve um contraste de cores - entra a família dos azuis e amarelos (o amarelo saltou). 

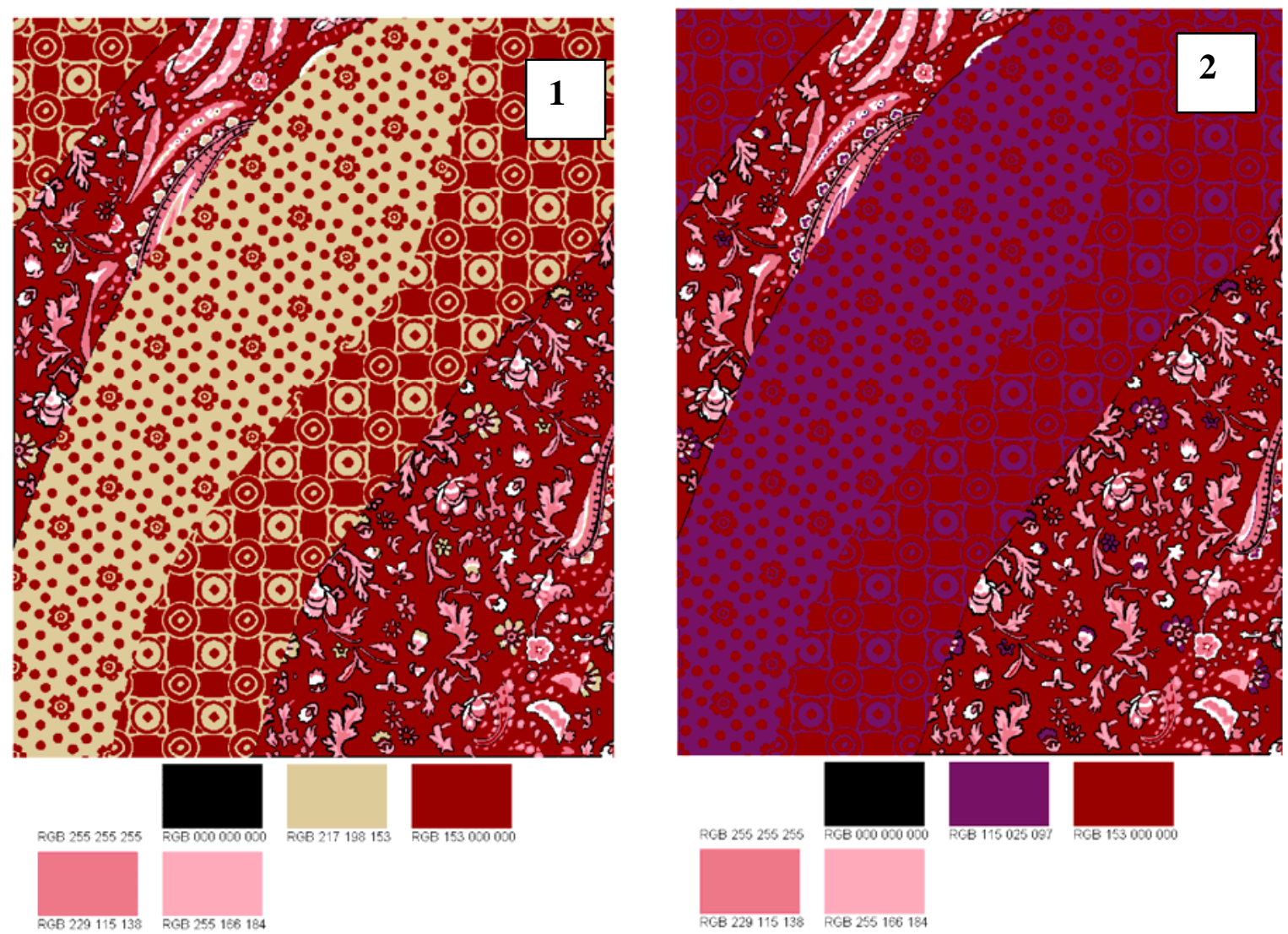

1. Família dos amarelos e magentas - o filete deu forma.

2. Entra o roxo (família dos magentas) e não houve harmonia. 
${ }^{1}$ Barros, Lílian Reed Miller - A cor no processo criativo - pág. 15.

${ }^{2}$ Calvo, 2001 - pág. 110

${ }^{3}$ Pedrosa, Israel - A beleza do colorido - 2003 - pág. 19.

${ }^{4}$ Marcolli, Attilio - Teoria Del Campo - corso di educazione alla visione - Sansoni Editores S.p. A Firenza, Itália - $2^{\circ}$ Volume - pág. 378 a 402.

${ }^{5}$ Golding, 1997.

${ }^{6}$ Golding, 1998 e Pedrosa, 1989.

${ }^{7}$ Golding, 1997.

${ }^{8}$ White; Golding, 1997.

${ }^{9}$ Pedrosa, 1999 - pág. 160.

${ }^{10}$ Chazel, apud Fischer-Mirkin, 2001 - pág. 27. 


\section{O DESENHO E CRIAÇÃO DA PADRONAGEM}

\subsection{Manual}

O desenho de estamparia têxtil feito a mão requer do desenhista um repertório rico em informações sobre técnicas de pinturas, tais como: xilogravura, aquarelados, pastéis, acrílicas, texturizados, craquelados, batiks, esponjados e seus diversos materiais como: tintas, pincéis, papéis etc.

Conhecimentos em desenho, como traço, luz e sombra, perspectiva, volume, profundidade, geometria, anatomia, bem como boa cultura nos estilos afros, ameríndios, nativos brasileiros e estrangeiros, art-nouveau, clássicos, estilizados, modernos, cleans, xadrezes ingleses, traços orientais, europeus, entre outros, são requeridos.

Ao iniciar um desenho para estampas de tecidos, o desenhista, juntamente com o gerente de produtos, caso seja funcionário de uma indústria têxtil, discutem o tipo de desenho e técnicas para que o produto seja desenvolvido. Após estas informações, não esquecendo as partes técnicas em relação à rapport, quantidade de cores e efeitos que serão utilizados no desenho, o desenhista começará a desenvolver um novo "padrão de desenho". (Padrão: linguagem utilizada para desenho em rapport).

Etapas de criação do desenho têxtil manual

TRAÇO $\rightarrow$ Materiais utilizados:

- Mesa prancheta, luminária, papel vegetal, lápis, borracha, régua paralela na prancheta, esquadros, fita adesiva para fixação do papel, livros e revistas para pesquisas de desenhos. 

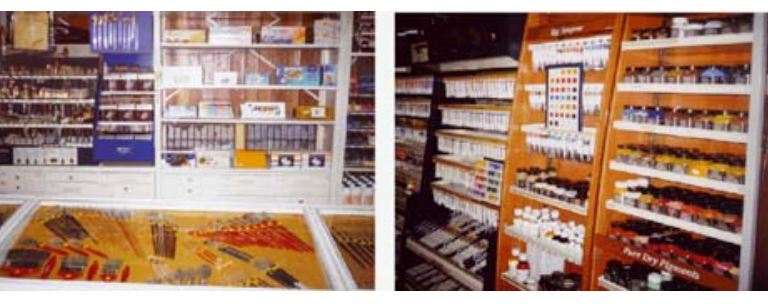

Nesta etapa, o desenhista começa a esboçar o desenho. Como exemplo, um floral: pesquisam-se estilos de flores e folhas nos livros ou revistas.

Como o desenho já foi definido na reunião com o gerente de produtos, as pesquisas serão direcionadas no que se refere aos estilos de traços no desenho, que também podem ser criados sem referências, mas isso dependerá da experiência do desenhista.

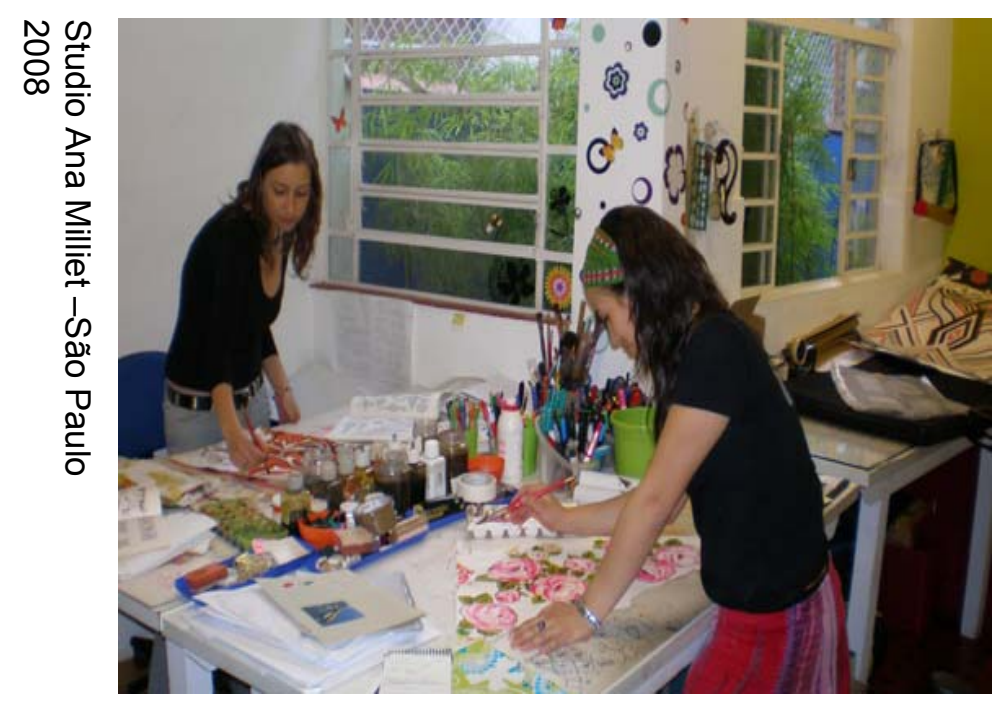

A primeira etapa é traçar no papel vegetal as linhas de marcação do rapport: (16X16), (32X32), (64X64) $\mathrm{cm}$ ou outras medidas que estejam dentro de $64 \mathrm{~cm}$ de rapport. Este assunto será abordado detalhadamente à frente.

As medidas vão depender do tamanho das flores que serão desenhadas. Feitas as marcações, o desenhista começa sobre o papel vegetal, orientando-se pelas linhas marcadas. A partir daí, inicia-se um trabalho de dobras em diversas partes do vegetal para poder ser criado o rapport, dando a idéia da repetição do desenho. Somente assim, o desenhista poderá perceber se o desenho estará correto ou não.

Concluído todo o desenho feito a mão com o lápis sobre papel vegetal, inspecionase o traço do desenho e as medidas do rapport. 

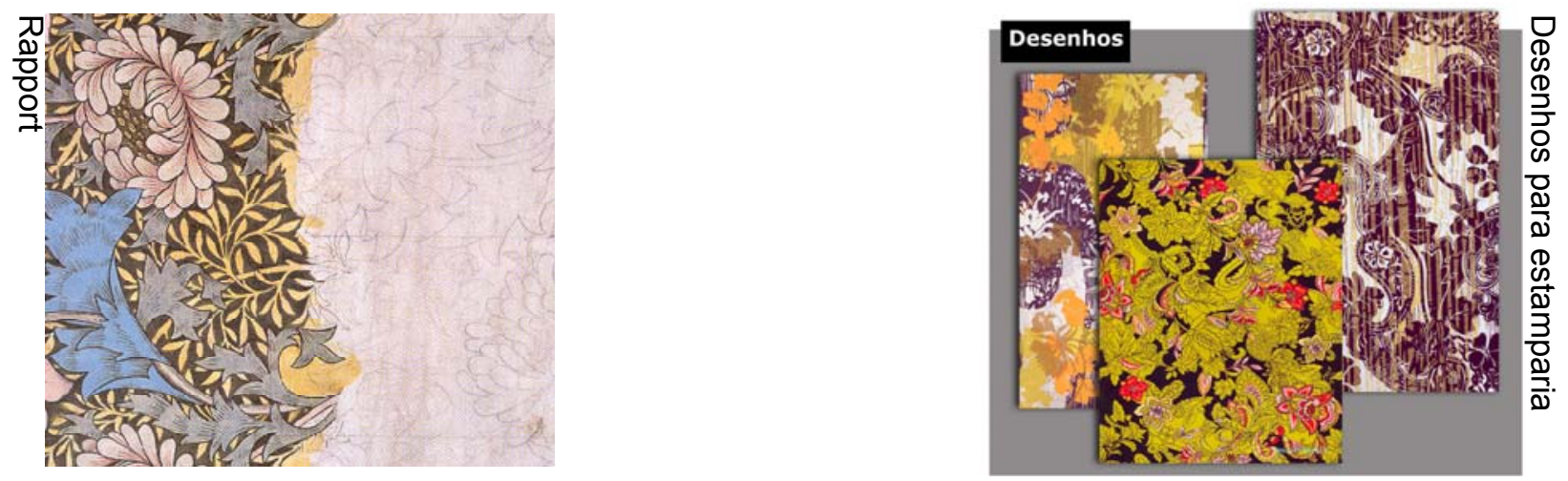

Os materiais utilizados para pintura são:

- Papéis: canson, shoeller, cartolina, color plus, color set, fabriano etc.

- Tinturas: guache, ecoline, acrílica, pastel, nanquim, látex e aquarela. Pincéis diversos em números e formatos, tira-linhas, compasso, esquadros, réguas, fita adesiva, máscara líquida, acetato, esponjas.

- Aerógrafos, papel carbono, escova de dentes, estilete, curva francesa.

- Recipientes para água para misturas de tintas e limpeza dos pincéis, água, flanela e secador portátil.

Esta etapa inicia-se fixando o papel canson, cartolina ou schoeller com fita adesiva sobre a prancheta.

Sobre o papel fixado, coloca-se o desenho feito no papel vegetal e entre os dois uma folha de papel carbono, todos os três com o mesmo tamanho e também, todos fixados com fita adesiva.

Com um lápis de ponta bem fina ou lapiseira $n .{ }^{05}$, traça-se sobre o desenho que está no papel vegetal para que este, através do carbono, seja transferido para o papel canson ou schoeller. Feito este processo, retira-se o carbono e o papel vegetal e deixa-se apenas o papel canson ou schoeller fixado na mesa prancheta, já com o desenho em sua superfície. 
Inicia-se então, a pintura do desenho com os materiais que procurarão dar o efeito desejado para o estilo de desenho a ser estampado. Geralmente é utilizada tinta gouache ou ecoline, por serem as mais comerciais, de fácil utilização e atóxicas.

\subsection{Digital}

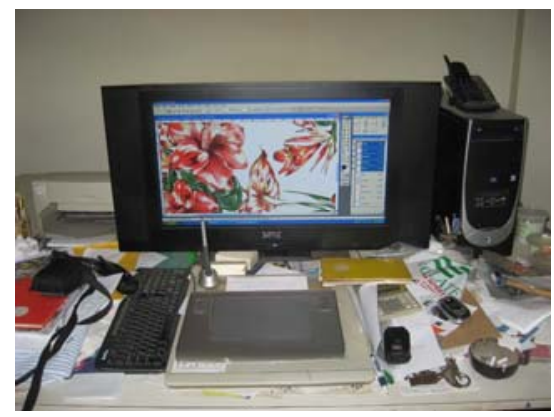

Os primeiros computadores comerciais foram introduzidos no mercado na década de 50, proporcionando mudanças radicais em todas as áreas de trabalho.

Nos anos 80, segundo Jones (2002), computadores e sistemas para a indústria da moda foram vendidos como sistemas autônomos, chamados CAD/CAM (Computer Aided Design e Computer Aided Manufacturing ou Desenho Assistido por Computador/ Manufatura Assistida por Computador).

Esses sistemas não só podiam organizar e tornar mais ágeis os processos de desenho, como também eram capazes de operar uma máquina, como um tear ou um aparelho de corte a laser. A princípio, essas unidades não podiam comunicar-se entre si, os programas tinham um tipo particular de interfaces e requeriam uma configuração própria. Estes sistemas são, todavia, efetivos e são utilizados em escritórios de moda e projetos de produção. Goulart e Genoveva (1997) comentam que, por serem versáteis, os sistemas CAD podem ser utilizados por diversos setores onde o desenho é o objeto de trabalho.

O computador trata a informação visual de duas formas: vetores e mapas de bits (JONES, 2002: 74). Tratando-se de vetores, as formas mais populares de ilustração por computadores são os desenhos técnicos e as especificações. Ambos são necessários porque correm menos riscos de serem mal interpretados pelo fabricante do que um desenho simples. O modo mais eficiente de fazer este trabalho no computador é com uma linguagem chamada "vetores orientados pelo objeto" ou simplesmente "vetores". A linguagem vetorial PostScript, desenvolvida pelo Adobe, 
é ideal para desenhar linhas, curvas e formas geométricas porque sempre produz linhas mais afinadas e suaves, sem ângulos dentados ou imagens borradas, linhas que o monitor do computador ou a impressora são capazes de reproduzir, sem importar se o tamanho da imagem está reduzido ou ampliado. Os arquivos vetoriais ocupam pouca memória e não perdem qualidade em função do tamanho. Os padrões e as especificações podem ser transmitidos para o mundo todo, recebidos com rapidez e se adequarem às medidas.

Os programas de computadores utilizados na criação de desenhos de repetição para estamparia têxtil são programas específicos com este fim, denominados de CAD - têxtil.

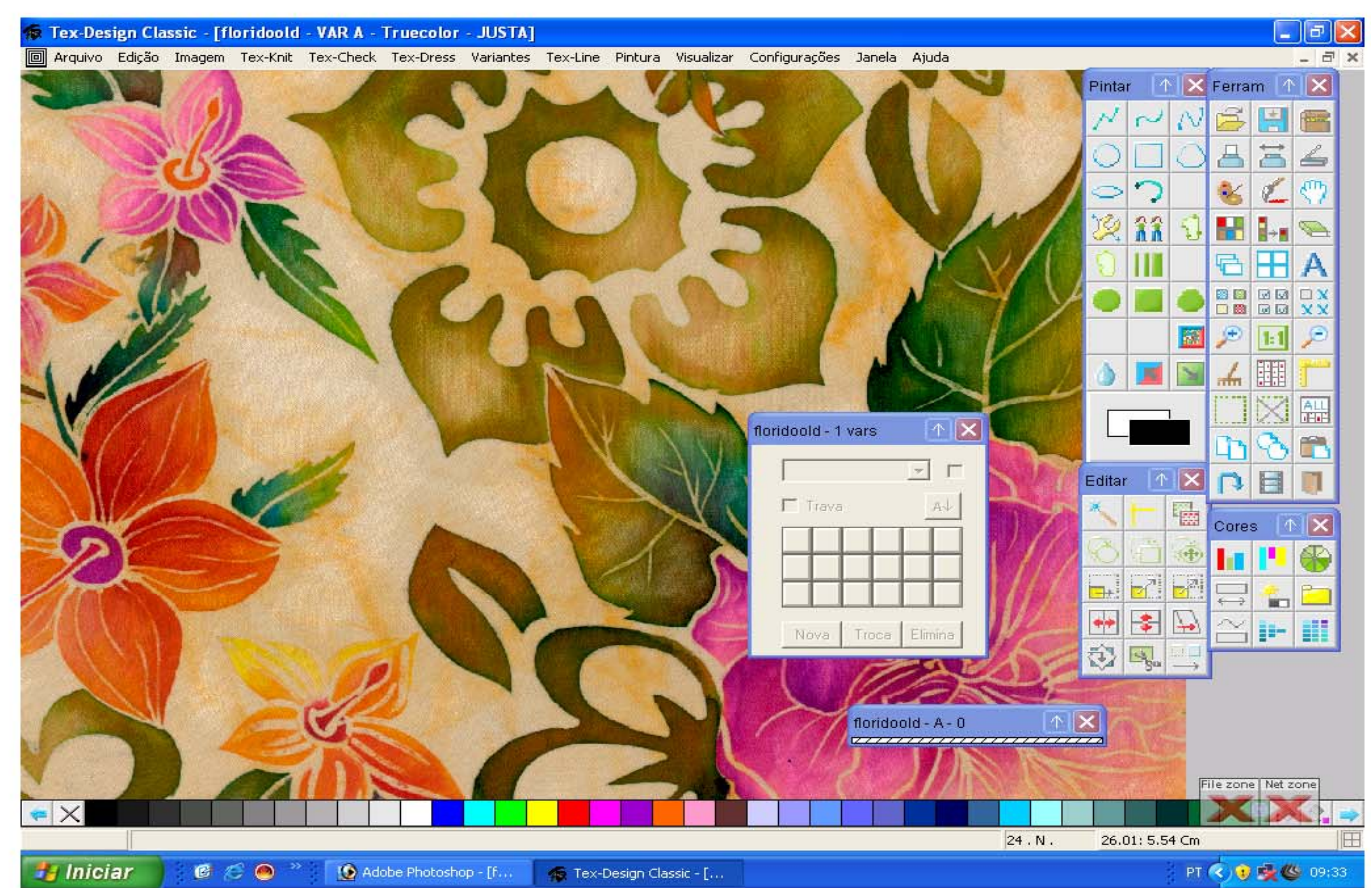

No mercado, encontramos os programas específicos para Estamparia Têxtil e Moda como: Vision, da Nedgraphics, Design Scope, Tex-Design (o mais utilizado no Brasil), Pixelart. 
Através destes programas, o desenhista terá a capacidade de criar qualquer tipo de desenho têxtil, com traços, texturas e dimensões diversas, com muita rapidez e custo baixo. Algumas empresas utilizam programas mais baratos e menos eficientes, pois não são programas desenvolvidos para a criação de rapport e negativos. São eles: Corel Draw e Photoshop.

\subsubsection{O processo de criação digital}

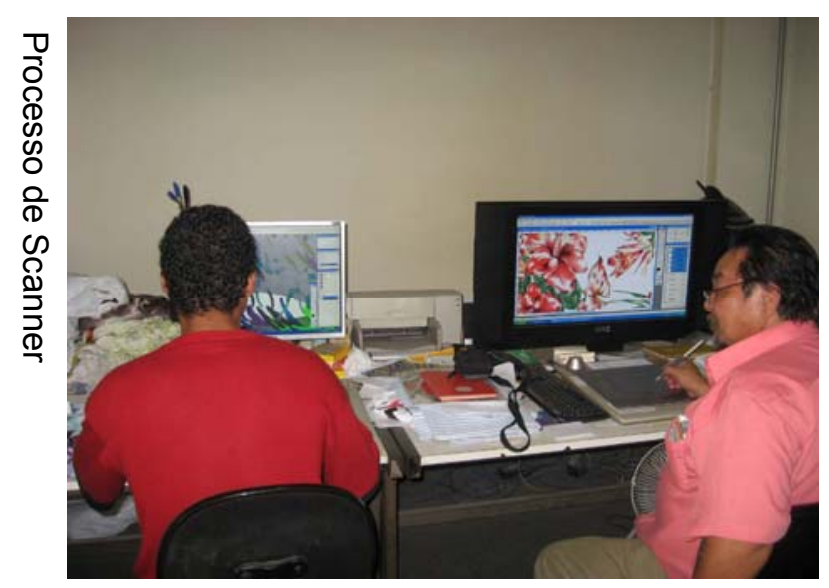

Através de uma máquina denominada scanner, o desenhista capta imagens de desenhos têxteis feitos manualmente, de livros de artes e outros.

SCANNER:

- No momento da digitação da imagem, o desenhista determina alguns padrões necessários para uma boa imagem escaneada: a resolução da imagem, que é a nitidez, geralmente se utiliza uma DPI de 254 ou 261. Esclarecendo que: $\rightarrow$ DPI significa a quantidade de pixels por polegada. Pixel é o menor ponto da tela do computador. Quanto maior for o DPI, melhor será a qualidade da imagem digitalizada.

Também se faz necessário definir o tipo de imagem, geralmente em "milhões de cores", é a opção que capta a maior quantidade de tons da imagem. Se for uma imagem preta e branca, escolher tipo de imagem "desenho em preto e branco". Estas padronizações são determinadas dentro do programa do scanner, no momento da digitalização da imagem. 
O desenho têxtil também pode ser criado diretamente na tela do computador através de caneta ótica e do mouse, que substituem o lápis e o pincel. Grava-se também, para o desenho feito computador, sem o uso do scanner, a DPI correta. Mesa com caneta digital e mouse.

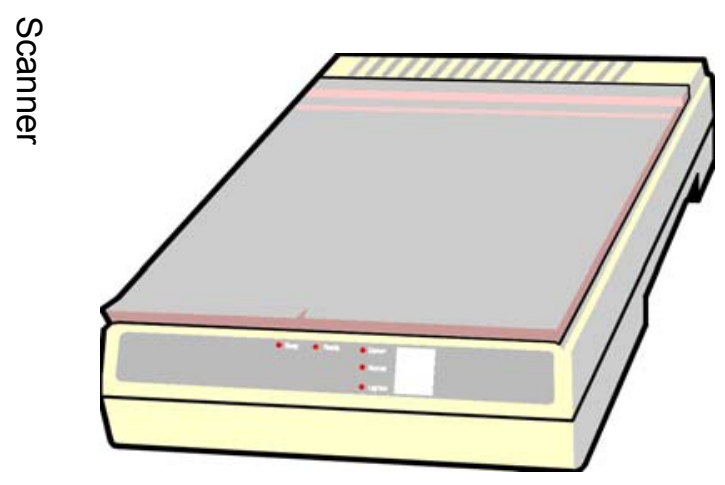

Feito todo o processo de digitação da imagem, a mesma é gravada com um nome qualquer em um arquivo do programa de design do CAD - têxtil, onde será trabalhada pelo desenhista.
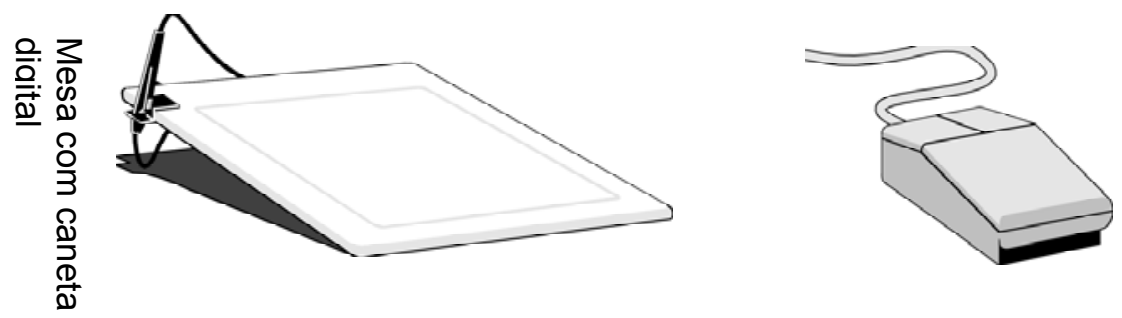

Tem início, então, o desenvolvimento do desenho através desta imagem. Neste momento, o desenhista determina o rapport que terá sua repetição para a gravação dos cilindros ou quadros. As repetições mais utilizadas são: rapport direto e rapport meio salto vertical. Cria-se também, na paleta de cores do programa, as que são necessárias para iniciar o trabalho. Definiram-se tipos de lápis, espessura da ponta ou tipo de pincel, airbrush etc., todos com apenas um clique nos ícones desejados.

Nos programas CAD - têxteis, os desenhos são criados com a utilização da caneta ótica sobre a mesa digitalizadora, conhecida como Wacon. Esta caneta tem a forma de um lápis. Utiliza-se a caneta ótica da seguinte forma: o desenhista mantém sua visão na tela num ponto do desenho, e na mesa digitalizadora, com a caneta ótica, segue o traço sobre o desenho digitalizado na tela.

Neste ponto, é muito importante desenvolver esta habilidade de desenhar sem olhar para o traço na mesa, e sim, de observar o traço que está sendo desenhado na tela, 
sabendo que é o mesmo traço que está sendo feito com a mão sobre a mesa digitalizadora. Com a caneta ou o mouse, todo o desenho é desenvolvido, utilizando os ícones e ferramentas do programa. Para cada ícone está simbolizado um material de trabalho necessário para desenhar, apagar, copiar, gravar etc.

Enquanto o desenho é elaborado, o desenhista vai "salvando" o processo que está sendo desenvolvido, com um ou vários arquivos do mesmo desenho. Estes arquivos podem ser salvos no próprio programa de CAD - têxtil, dentro de subpastas criados pelo desenhista, ou salvos em Zip disk, CDs ou pen drives. É muito importante que o desenhista grave o desenho com dois ou três arquivos diferentes, evitando, por exemplo, queda de energia, que poderá prejudicar o trabalho feito, se este não foi gravado a tempo.

Finalizando o desenho, revisa-se o mesmo em suas quantidades de cores, tipo de repetição do rapport, DPI e os negativos do mesmo, sobreposições de cores e suas misturas. Os negativos são criados simultaneamente no momento em que está sendo feito os traços do desenho. Para cada cor do desenho têxtil existe um negativo que serão gravados separadamente em cilindros ou quadros.

Grava-se então, o arquivo final que será enviado para a fábrica para a gravação dos cilindros ou quadros, e também outro arquivo final e igual como cópia de segurança. As imagens são gravadas em Zip disk, CDs e Pen-drive.

No processo digital são possíveis similares as variantes de cores para um padrão de desenho têxtil. Este processo facilita o trabalho do setor de estamparia, pois podem ser escolhidas acertadamente as cores que irão ficar mais harmoniosas com 0 desenho.

\subsubsection{Análise: Desenho de Estamparia Manual x Digital}

Tenho pintado durante 25 anos e sempre disse que nunca usaria um computador, mas agora não posso me separar do meu. O tempo perdido em refazer coisas se o cliente quer mudar algo é menor, e se cobra o mesmo. Cada centavo valeu a pena. O grande avanço tem sido a caneta digital, que é como usar uma pena e um lápis Neil Greer ${ }^{1}$. 
Com a aceleração rápida do consumo a partir da revolução industrial, os produtos que utilizam o desenho de estamparia, na sua grande maioria, tecidos em geral, ganharam maiores opções de estilos e padronagens e uma velocidade de produção altíssima.

Quando surgiram os primeiros produtos com estamparias, sua produção era bastante limitada, devido ao processo de estampar, que praticamente, era artesanal. Com o advento da tecnologia avançada, que hoje podemos presenciar, as indústrias têxteis de grande porte desenvolvem infinidades de padronagens para tecidos, nos mais variados tipos de estilos e qualidades.

Num mercado cada vez mais globalizado e concorrente, estas grandes indústrias ficaram mais ágeis, colocando em praticamente todos os setores da empresa sistemas computadorizados.

Com a informação no departamento de criação de novos produtos e profissionais que assimilaram esta tendência mundial, ficou mais rápido o desenvolvimento e a criação nas empresas. O computador utilizado na criação tornou o ato de desenhar, que era lento e trabalhoso, em um trabalho rápido e produtivo.

\subsection{Rapport}

Palavra francesa que se traduz por relação ou, em termos populares, de repetição. É uma técnica de desenho de estamparia corrida, que se refere à continuidade de um módulo de desenho, não existe princípio nem fim da estampa. No entanto, para que isso se dê é necessário desenvolver o desenho, de modo que os motivos se encaixem nas extremidades superior, inferior e lateral, respeitando as dimensões das telas de impressão.

Assim sendo, o desenho de repetição produz a sensação de continuidade na formas das estampas dos tecidos, como se as emendas do desenho não existissem. 
O desenhista, quando vai criar um desenho de estamparia, já visualiza como será o rapport do desenho, a largura do tecido que será estampado. Ele também se preocupa com a estética do desenho, dando um equilíbrio e movimento nas formas e cores, que são requisitos fundamentais.

Um desenho pode ser lindo, mas se não for rapportado de maneira correta, a relação entre figuras e cores será muito desequilibrada, ficará um "buraco" na estampa ou até a figura poderá ficar sobreposta.

Para a perfeita composição do rapport, é necessário saber para que tipo de peça será destinado: vestido, blusa, calça, para que os moldes da roupa sejam encaixados, geralmente no sentido de altura, ou seja, cortados paralelo à ourela, ou margens do tecido. Por isso a direção das figuras não pode ter pé, ou seja, os desenhos não podem ser de uma só direção.

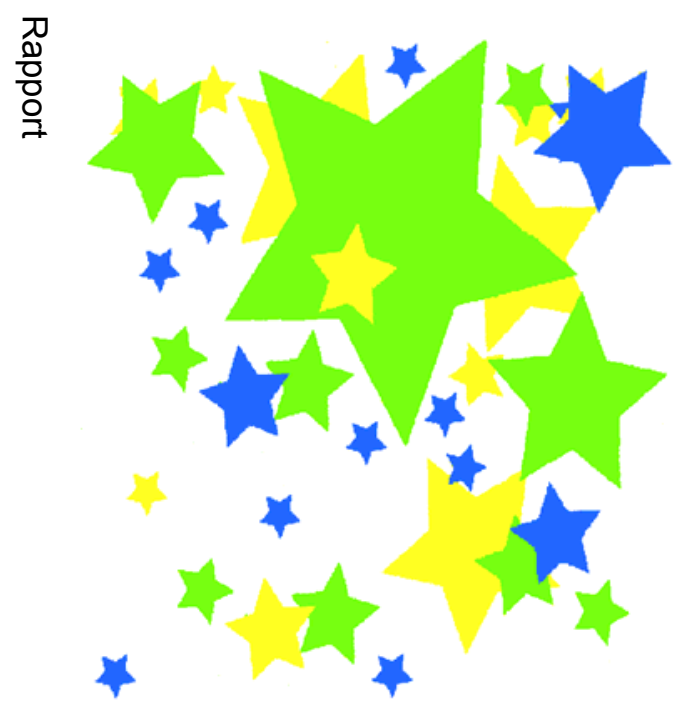

Existe uma padronização para a gravação do desenho rapportado.

Para estampar em cilindros (rotativas), a medida padrão do rapport no comprimento do tecido, é de $64,02 \mathrm{~cm}$, ou seja o diâmetro do cilindro.

Existem outras medidas de rapport maiores, de 90, $1.00 \mathrm{~cm}$, utilizados para estampas de tapetes, por exemplo, mas são poucos usados pelas maiorias das indústrias.

Na estamparia em cilindro, o perímetro do cilindro é o que define o rapport, ou seja, os dízimos de 64,02cm ( 34,01 cm; 17,05 cm; 8,02 cm; e assim por diante. A largura do rapport não é necessário levar em consideração, pois os tecidos têm geralmente $1,50 \mathrm{~m}$ de largura.

Na estamparia a quadros não há um padrão a ser seguido, a medida de $64 \mathrm{~cm}$ determina o rapport no comprimento do tecido; em sua largura o desenho pode variar de tamanho, dependendo do tipo de desenho e sua dimensão. O rapport pode 
ser de 5, $10 \mathrm{~cm}$ de largura até a medida total do tecido, de uma ourela a outra. É na ourela do tecido que vem gravado o nome do fabricante e o número de cores da estampa.

\section{Tipos de Rapport}

Vários são os tipos de Rapport existentes, sendo mais comuns os tipos: Direto; 1/2 Saltado: Horizontal e Vertical; Rapport especial: Listra e Barrado.

\section{- Direto}

Através da figura de um quadrado localizamos a repetição de qualquer objeto nele distribuído.

O rapport direto são as repetições dos módulos lado a lado, tanto na horizontal como na vertical. Este tipo de rapport é mais utilizado para desenhos pequenos.

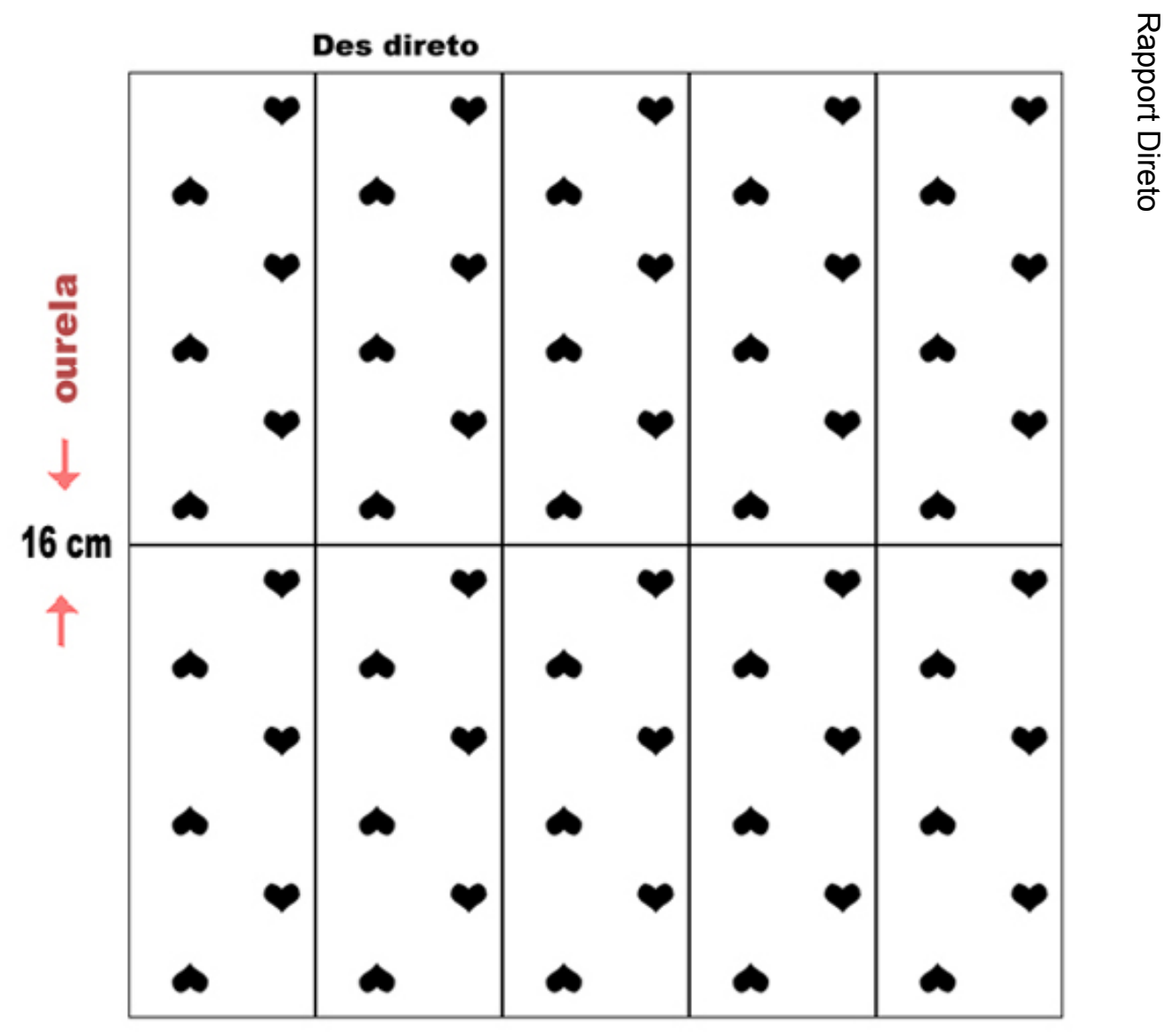




\section{- $1 / 2$ Saltado Horizontal}

Este tipo de rapport é indicado através da figura de um triângulo na horizontal e na vertical. Aplicase o rapport saltado para desenhos maiores, 0 desenho fica esteticamente mais equilibrado.

No meio salto horizontal, o rapport é gravado paralelamente, mas ao gravar a próxima fileira de rapport acima da que já foi gravada, esta é deslocada, passando a ser gravada a partir da metade da primeira gravação.

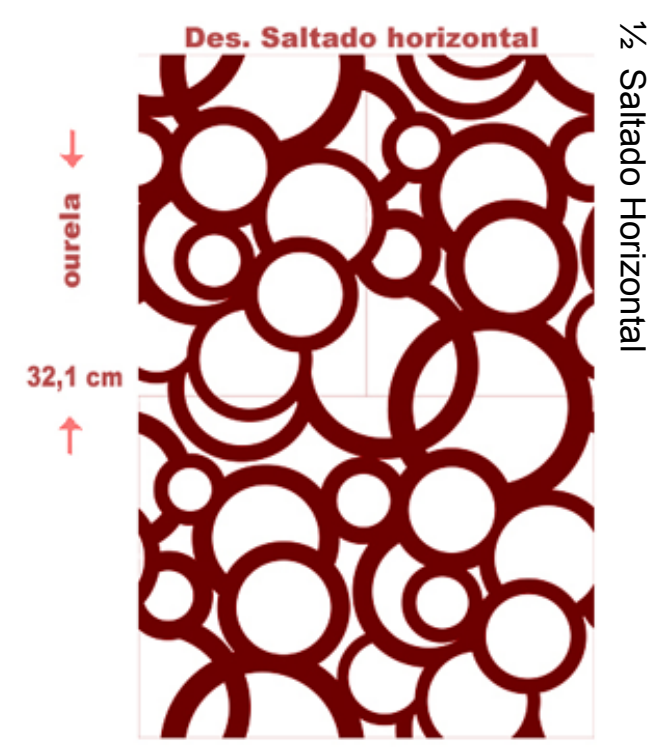

Nos rapports de meio salto horizontal, as medidas de atacadura (limite do desenho raportado em seu comprimento), devem ser submúltiplos de $64 \mathrm{~cm}$, nunca a medida total do cilindro, pois o encaixe do rapport não dará continuidade.

- $1 / 2$ Saltado Vertical

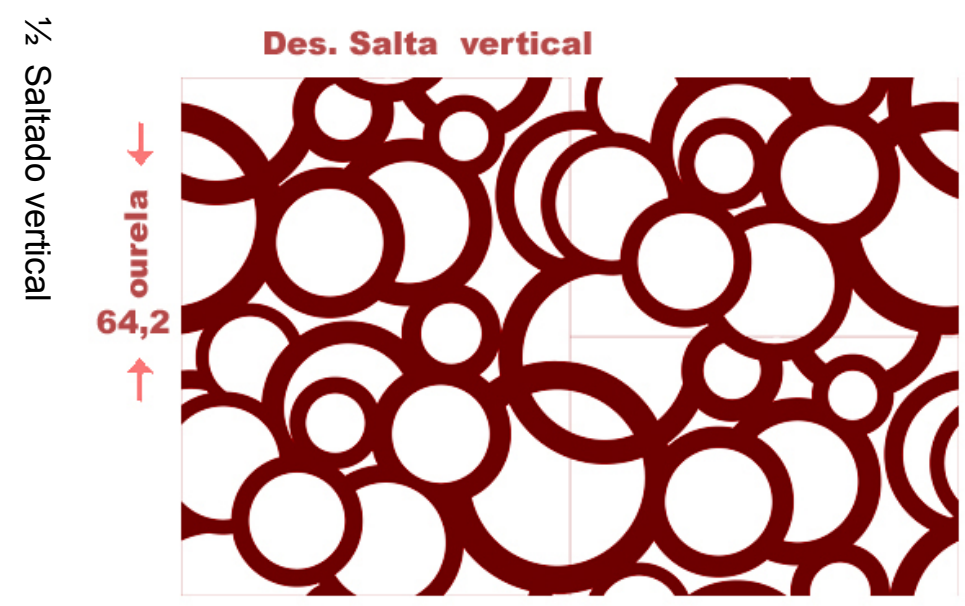

No meio salto vertical, o rapport é gravado da seguinte forma: Começando da ourela, a partir do segundo encaixe de rapport, este é deslocado para a metade do anterior, e assim com todos, até chegar à outra extremidade, intercaladamente. 
- Listra

No caso de listras, não existe rapport no sentido do comprimento do tecido, mas somente na largura.

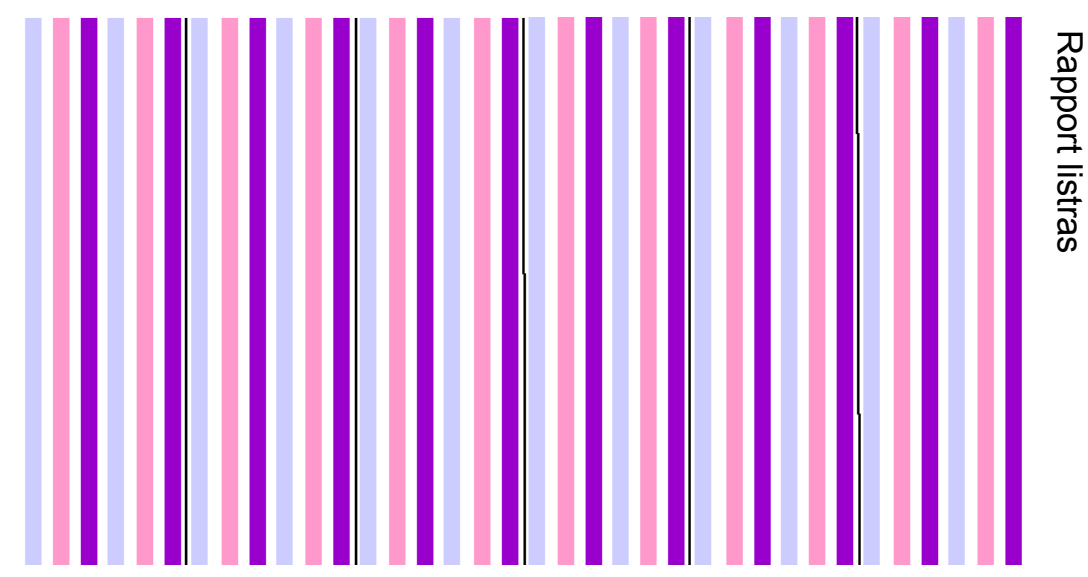

- Desenho Barrado

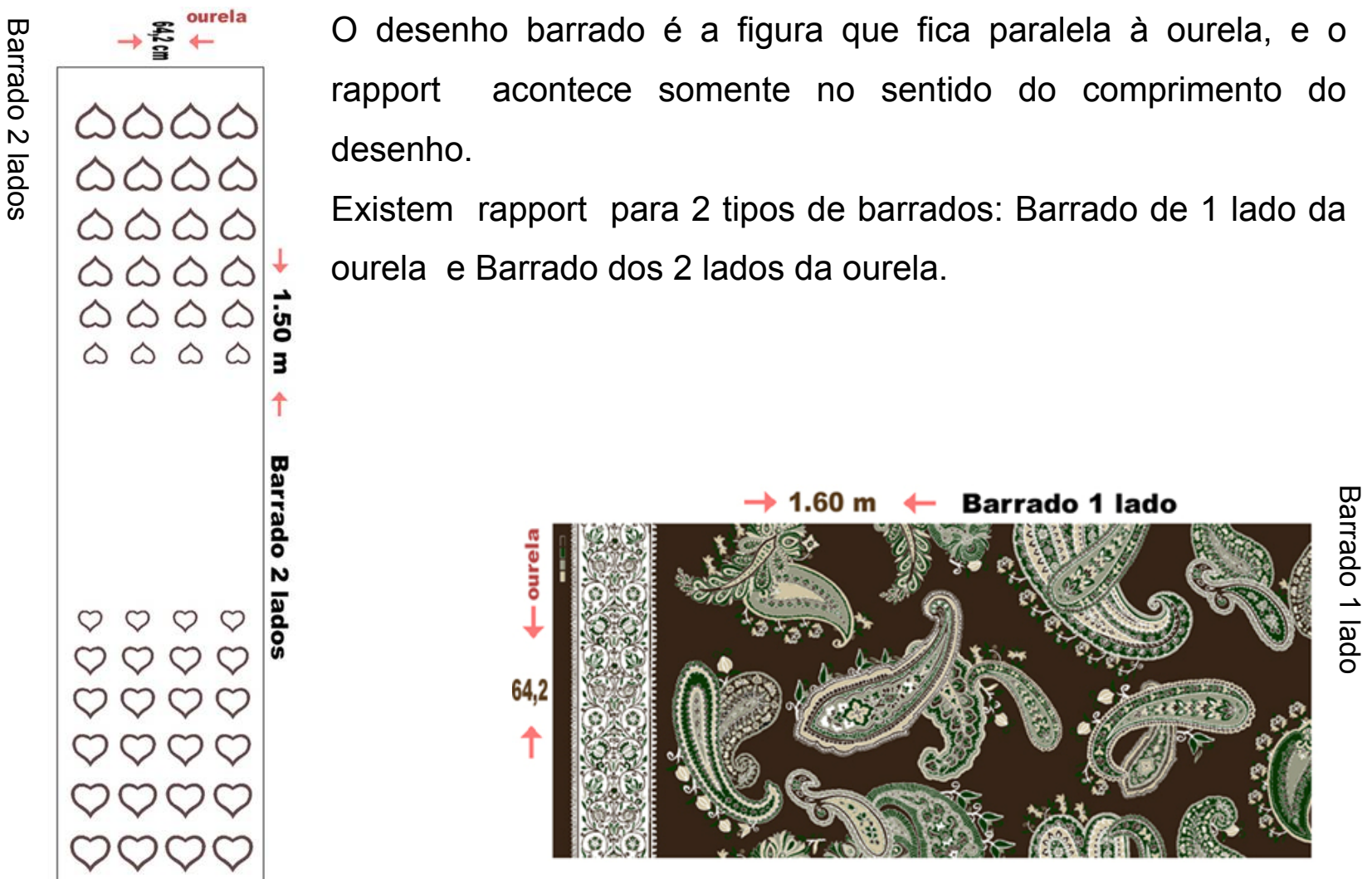




\subsection{Relação Arte e Estamparia}

O conceito de belo é eminentemente histórico, cada época traduz novos conceitos e por esta ótica é de conhecido que em todo século $X X$ ocorreu um vínculo entre 0 artesanato e o design no que diz respeito ao desenvolvimento dos tecidos, que neste contexto tem-se revelado forte.

$\mathrm{Na}$ verdade na maioria das vezes, os próprios "designers" são os tecelões ou os estampadores de profissão que acabam por levar sua experiência para a prática, no que entendemos por processo de design.

Entretanto, na escola Bauhaus, em suas oficinas de tecelagem, podemos ter como exemplo que havia uma sólida crença no uso do design artesanal como apoio à tecelagem industrial.

Há também a necessidade de citarmos alguns pintores famosos que exerceram uma notável influência sobre o "design dos tecidos", dentre eles:

- Raoul Dufy, que chegou a trabalhar diretamente com tecidos;

- Paul Klee, que criou impacto quando lecionou na Bauhaus de 1920 a 1931;

- Gunta Stölzl, que tinha uma experiência como tecelã, numa obra de evidência;

- E a obra de Ruth Reeves, que era residente em Paris e que foi influenciada pelo contato com os cubistas; designers modernos, como Collier Campbell, que conservam a ligação com o mundo da pintura, adotando assim um enfoque nitidamente pictórico nas elaborações de padrões. 


\subsubsection{Willian Morris e a relação Arte e Indústria}

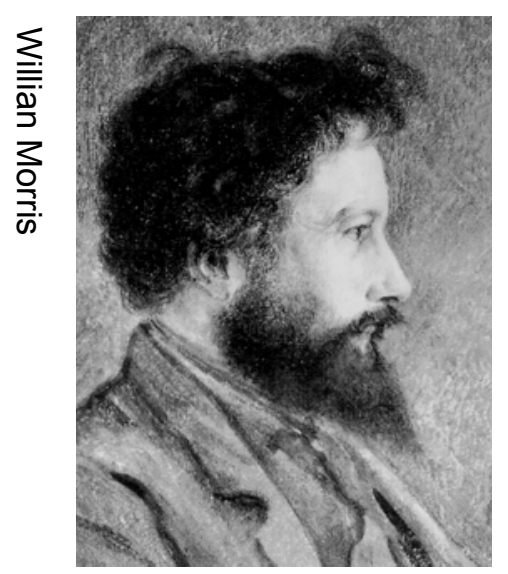

Willian Morris (1834/1896) tornou-se conhecido não só por ser escritor e poeta, mas também por se destacar como pintor e desenhista; contudo se evidenciou pelo seu conceito filosófico de um homem reformador e realizador.

Morris tinha preocupação com relação à "qualidade do ambiente", onde o mesmo tentava amenizar a vida do dia-a-dia dos operários que se encontravam aglomerados nas habitações de Taine, penitenciária da Inglaterra onde, em suas notas sobre o país, sob sua ótica, comparava o local como o último círculo do inferno.

O período da Idade Média era sua paixão, herdada por influência de Ruskin, que em seu conceito pretendia que a sociedade industrial fosse revigorada pela adaptação aos princípios e usos que existiam antigamente.

A intensificação dos trabalhos de Morris não pára por aqui, ele também imaginava uma idade de ouro onde os artistas tomariam o lugar de chefes de indústrias, trazendo o bem-estar e a eficiência na condução dos trabalhos.

Morris considerava que a máquina e a produção industrial são as calamidades do mundo moderno, tanto no plano estético quanto no plano social.

Abandona o estudo da arquitetura para dedicar-se à pintura, pois nesta ocasião o mesmo se encontra entusiasmado pelos primeiros quadros de camarada de Oxford.
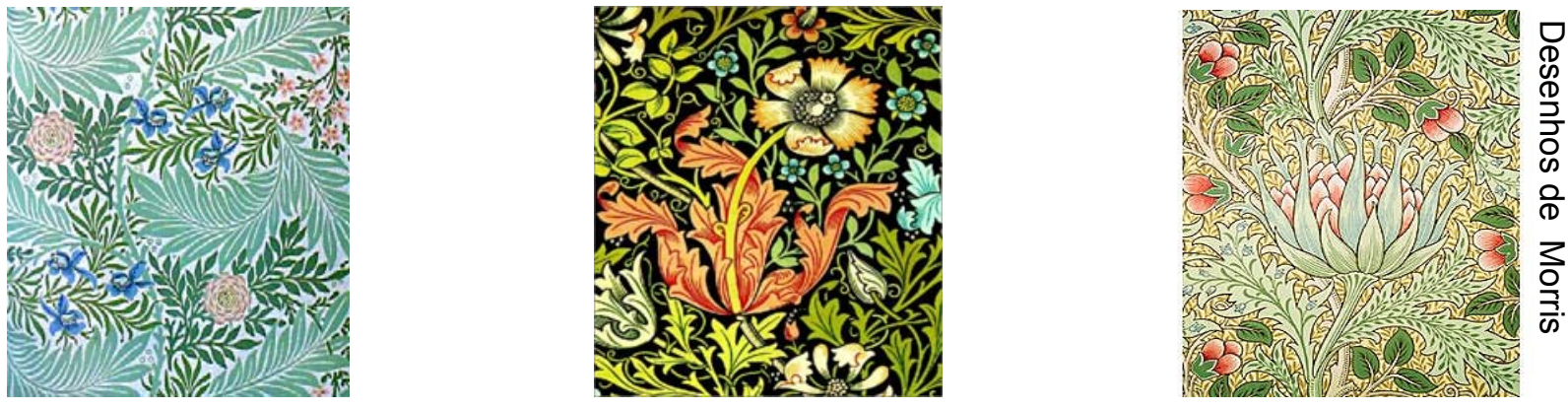


\subsubsection{Bauhaus e o design contemporâneo}

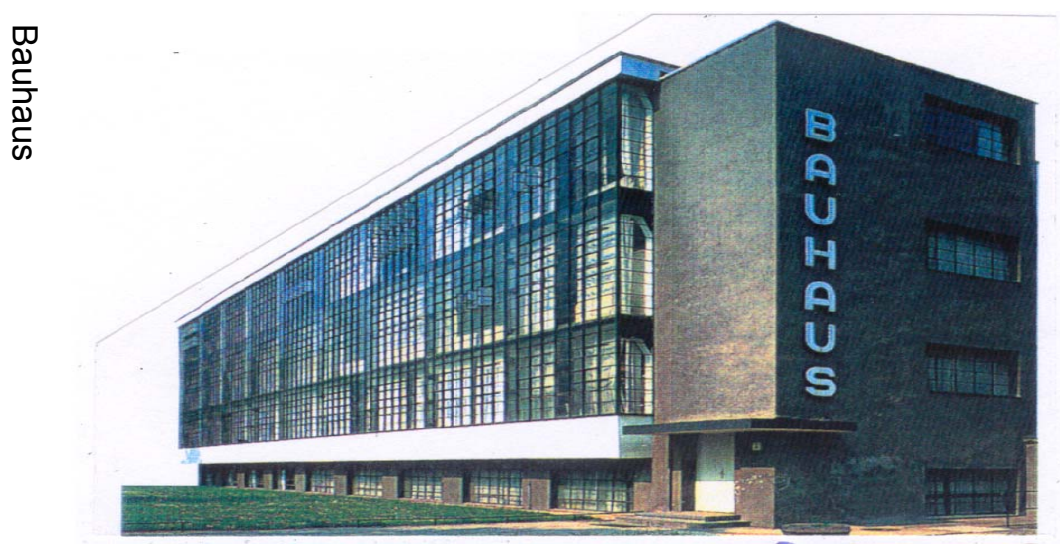

Em 1919, na cidade de Dessau (Alemanha) escreve-se um período que vai até 1933 de importância relevante, na qual a antiga escola de Artes e Ofícios sai de cena e passa a se destacar o então Instituto

Superior da Forma. O mesmo traz uma marca significativa com a presença do então diretor e idealizador da nova escola alemã, Walter Gropius.

Contudo, é importante salientar que neste período o instituto sofre influências de Johann Wolfgang Von Goethe (1810), sendo que a Bauhaus é uma das escolas de maior influência do século e deixa grande marca sobre o design do século XX.

Dentro da estrutura da Bauhaus, distinguem-se três objetivos básicos desta escola:

1. Democratizar a arte;

2. Derrubar as barreiras entre a "Arte Vulgar" e a "Arte Elevada";

3. Estabelecer a parceria entre "Arte e Indústria".

É importante ressaltar o pensamento de Whitford, com relação ao terceiro objetivo básico da estrutura da Bauhaus, estabelecer "um contato constante ente os artífices e as indústrias do país, era uma questão de sobrevivência econômica". A Bauhaus espera se livrar gradualmente da dependência do subsídio estatal, vendendo seus produtos e design ao público e à indústria. Ao mesmo tempo, o contato com o mundo externo evitaria que a escola se tornasse uma torre de marfim e integraria seus estudantes na vida prática. ${ }^{2}$

Dentro do universo da Bauhaus, encontramos grandes mestres e os mesmos tinham por conceito a liberdade de criar metodologias para formar um profissional industrial. 
Nesse contexto, os mestres da Bauhaus mostram que, com sua sensibilidade artística, procuravam encontrar na interpretação das formas e das cores os símbolos universais da comunicação visual. Que buscavam estes artistas?

\begin{abstract}
Esses artistas buscavam nas origens mais puras da forma e da cor, libertando-se de todos os preconceitos artísticos, as ferramentas básicas para uma resposta atualizada às exigências modernas da sociedade da época (BARROS, 2006)
\end{abstract}

Dentre os grandes mestres que marcaram o desenvolvimento da Bauhaus, vale destacar os nomes de Paul Klee, Wassily Kandinsky, Johanns Itten, Joseph Albers e Gunta Sölzl.

Cada mestre da Bauhaus primava por um conceito; se estabelecermos uma comparação com o processo de pensamento de cada um, podemos dizer que enquanto Kandinsky e Klee enfatizavam desenvolver verdadeiras teorias sobre a composição plástica (cor em especial), por outro lado, Itten e Albers se preocupavam mais com as metodologias de ensino. Entretanto, "[...] para Klee assim como para Kandinsky, a arte é a operação estética, e a operação estética é comunicação intersubjetiva como uma clara função formativa e educativa". ${ }^{3}$

Johanns Itten tem em sua ótica o conceito que se deve libertar a criatividade dos alunos e afirma que há exercícios físicos cujo objetivo é unir o corpo e a mente. Outro fato também importante é a percepção visual através dos contrastes cromáticos, designados como sete tipos. Ele também diagnosticava a personalidade e a habilidade dos alunos através da preferência das cores e das formas.

Divergências de opiniões surgem entre Itten e Gropius e com isso Itten se desliga da Bauhaus no ano 1923, quando vai para Berlim onde acaba por dirigir sua própria escola (1926/1934). Durante este período ele também funda uma escola de desenho têxtil na Alemanha em (Krefeld), após algum tempo retorna à Suíça para se tornar diretor da Escola de Artes e Ofícios e também do Museu da Escola Têxtil de Zurique (1938/1954). 
Ïtten incentivou a prática da visualização imaginativa, fazendo com que os alunos tomassem consciência de três fases no decorrer dos exercícios: experiênciapercepção-habilidade.

Primeiro eu procurava evocar [nos alunos]uma sensação vivida para a determinação de um tema, pela experiência visual; depois,seguia-se a explicação intelectual e a sua compreensão, e só então partia-se para a execução da tarefa (BARROS, 2006)

As cores dos olhos e da alma

A magia das cores da paisagem africana inspira-o em aquarelas cheias de luz. $\mathrm{Na}$ obra de Paul Klee o elemento mais importante é a cor. Ele no início, lidava com as cores apenas sob uma perspectiva teórica, mas, mais tarde ele descobre que também a qualidade emocional das cores é importante.

Klee em uma viagem que fez à Tunísia afirmava que "A cor me possui. Eu e a cor somos um. Sou pintor". Durante esta viagem ocorreu uma grande transformação em sua obra.

Nas aulas ministradas por Klee na escola de Bauhaus (1921/1922), com respeito ao estudo das cores ele afirmava que: "A diferença entre um tom vermelho e uma cor que não contém nada de vermelho é imensa, e por isso, não interessava a ele o que o tom vermelho continha. Para ele interessava muito mais o que o "vermelho não continha".

Nas poucas telas que pintou, usou as cores com bastante moderação. No período que se refere ao início de sua carreira artística mostra em suas aquarelas que o valor do matiz de um tom em uma escala de cores despertava muito mais seu interesse do que o seu efeito psicológico.

É interessante observarmos que Klee trabalhava neste período principalmente com os diversos matizes e em especial com os tons avermelhados. Contudo, os tons de marrom e verde eram mais redundantes e isso só mudou depois que ele próprio declarou ter descoberto as cores. ${ }^{4}$ 
Klee utiliza cores intensas somente entre o período de 1913/1914, e declara que: "As cores primárias vermelho, amarelo e azul ganham em importância, assim como as cores contrastivas complementares, e esse processo ocorre dentro de toda a escala de cores". Ele tinha uma nova visão do mundo, com tons menos cinzentos.

Numa nova relação com as cores, Klee passa a desenvolver mais suas técnicas com relação à pintura a óleo, passa a nos apresentar composições mais abstratas, com linhas mais livres e seu trabalho reflete em muitas vezes experiências e vivências pessoais.

Entretanto, neste momento, surge em sua arte novos conceitos, como dinâmica do movimento e da relação entre a energia individual e a energia cósmica. Após alguns ele desenvolve, a partir dessa base, uma teoria de romantismo que, em vez de se orientar pelo classicismo, acaba por se orientar pela liberdade de expressão.

Klee transforma sua poética em teoria, a teoria em método dialético. ${ }^{5}$

É importante salientar que outra característica da Bauhaus era o estímulo à imaginação, embora seu objetivo central fosse a formação de desenhistas industriais e arquitetos, contudo os exercícios e eventos em áreas diversificadas como cenografia, direção, coreografia, ação cênica e dança, também eram incentivados e nesse sentido, as teorias da criação desenvolvidas pelos mestres pintores também ofereciam aos alunos uma visão nunca antes explorada: o processo de promoção. ${ }^{6}$

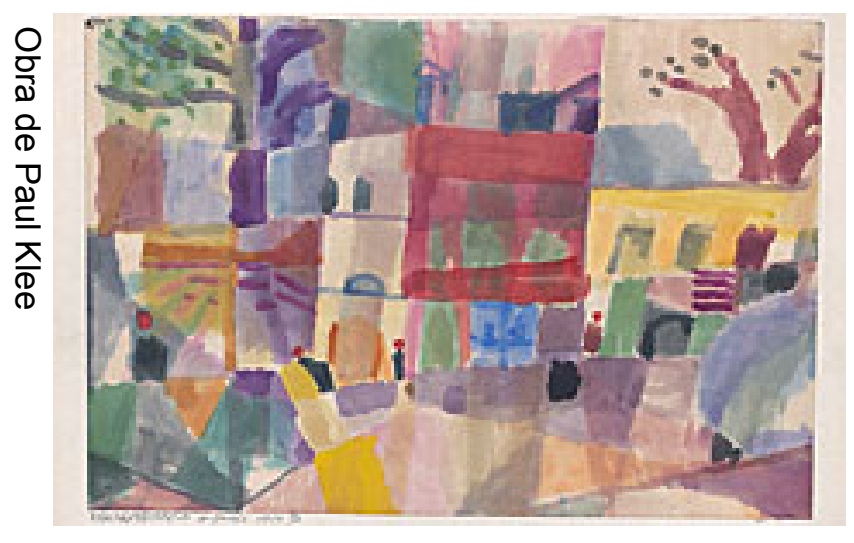

Para o mundo das artes, conclui-se que com suas descobertas sobre as cores e seus efeitos, Klee enriquece a arte moderna, não apenas como pintor, mas também como teórico. No processo com as cores, o artista Klee deixava-se guiar não somente pela sua intuição, mas também pelos seus sentimentos. ${ }^{7}$ 
Numa nova visão, tanto Kandinsky como Klee vêm associar a cor à música, numa abordagem muito poética e teórica. Eles apresentam três cores primárias com uma música. Em suas aulas Kandinsky apresentava na seguinte seqüência:

- Teoria das cores (cor isolada);

- Teoria das formas (formas isoladas);

- Teoria das cores e das formas (relação cor e forma);

- Planos básicos

Joseph Albers iniciou na escola Bauhaus como aluno do já consagrado Itten. Como Albers era um excelente aluno, o não menos notável idealizador da escola, Gropius, o convida para continuar na escola e mais tarde se torna professor assistente.

A metodologia que aplicava era didática, e também era voltada para um pensamento construtivo, baseava-se no método de tentativa de erro. Os exercícios aplicados eram propostos aos alunos sem uma teorização, de tal forma que eles procurassem respostas pela própria experimentação. Mais tarde esta metodologia para o ensino das cores passou a ser usada no desenvolvimento da percepção visual.

Não menos notável foi a grande mestra Gunta Stölzl, que foi nomeada mestre pelo atelier de tecelagem em 1927 e tem participação fundamental na escola Bauhaus. Mestra Gunta introduziu os mais variados sistemas de teares, os mesmos foram adequados tanto para efeito de aprendizagem quanto de produção e elaborou um curso de três anos na escola Bauhaus, que tinha duas fases, a seguir:

- Em primeira fase, um trabalho elaborado num atelier de aprendizagem;

- Na segunda fase, o trabalho era realizado num atelier experimental e modelo.

A escola Bauhaus possuía a sua própria tinturaria e por conta disso, a mestra Gunta também passa a lecionar na escola aplicando a teoria do ligamento e do material, portanto, com o início dos trabalhos feitos em Dessau, na Alemanha, o então designado "atelier de tecelagem" passa a se chamar "design industrial". 
O termo "designer" surgiu dentro da escola Bauhaus a partir dos trabalhos feitos pelos estudantes. Trabalhavam com material tecido com cores diferentes, as peças tecidas eram depois montadas como amostras e em seguida levadas a uma exposição, onde eram numeradas num processo consecutivo, inclusive com dados específicos sobre o seu peso e suas medidas.

Assim, os estudantes aprendiam observando cada fase, desde a produção, passando pela tinturaria e encomenda dos materiais, incluindo a tecelagem e dentro deste processo os alunos também podiam observar e aprender com as Aulas de Forma do então professor Paul Klee, onde eram estabelecidas as regras de aplicações de desenhos e da ordenação das cores. Com isso a Bauhaus cria dentro da indústria têxtil um novo conceito.

A título de conclusão deste processo, no ano de 1931, a mestra Gunta Stölzl pede demissão da escola Bauhaus.

\subsubsection{Relação Arte e Moda}

Neste tópico serão abordados alguns aspectos da moda versus arte numa alusão aos processos da estamparia, referentes à criação de moda com foco em estamparia. As diversas inspirações temáticas envolvem características autorais onde a criatividade evidencia a construção de texturas, imagens figurativas ou abstratas e definem formas estéticas.

Tais processos tratam da transformação de um objeto têxtil, que é realçado pelas interferências estruturais aplicadas sob a ótica do resultado de tratamento composto pelos elementos da estamparia e denotam a visualidade artística. Vale ressaltar que não afirmamos aqui ser a moda um objeto de arte na sua dimensão, apenas argumentamos alguns pressupostos relacionados entre os elementos percebidos na composição visual entre os dois campos.

De acordo com Moura (1994), 
Moda e arte possuem os mesmos elementos de composição visual da imagem relativos às formas, silhueta, linhas, volumes, cores e texturas. Neste sentido o objeto de moda versus objeto de arte compreende o "reflexo do seu tempo e de sua sociedade" por apresentarem a mesma condição, sendo ambos os objetos abertos e sujeitos à recriação, releitura e interpretação.

Como assevera Medeiros (2007):

Desta forma a moda e a arte estão presentes nas relações humanas no tempo e no espaço, compreendendo as relações sociais, políticas, econômicas, tecnológicas e culturais. Assim entende-se que a produção contemporânea de arte, da moda e do design expressa de forma simbólica a linguagem e a comunicação numa interação definida também pelas citações da arte pelo design e do design pela arte. Nesta perspectiva, estilistas e designers se apropriam das referências artísticas para imprimir expressões estéticas em suas criações, onde a estilização de formas, inovação de materiais, elaboração de interferências, estamparia, padronagens e texturas agregam técnicas que remetem ao design de superfície têxtil e personificam suas marcas. $\mathrm{Na}$ experimentação torna-se importante compreender a arte sob os aspectos imaginativos, inventivos, criativos como suporte para o designer de moda promover suas interlocuções artísticas. Esta relação à arte tem sido o suporte da inspiração e conexão com o processo de criação, entre outras interferências e influências que reiteram a inter-relação entre os dois espaços.

MOURA (1994) interage associando à relação moda-arte uma conexão possível e explica esta relação sob quatro aspectos discursivos:

Objeto de arte x objeto de moda - compreendem o "reflexo do seu tempo e de sua sociedade" por apresentarem os mesmos elementos de composição visual "formas, linhas, cores, volumes e texturas", portanto ambos são objetos abertos e sujeitos à recriação, releitura e interpretação. Deste modo, costureiros, designers se apropriam das referências artísticas para imprimir expressões da arte recriando e estilizando formas, inovando materiais, promovendo interferências e técnicas para atender a demanda de consumo na moda. Assim também personificam sua marca criativa.

A moda na arte - refere-se aos registros artísticos de obras de arte em forma de afrescos, pinturas, gravuras, esculturas, fashion-plates que retratam os modos e modas através dos períodos históricos. Sob este aspecto desenvolveu-se a ação da pesquisa para elaboração de protótipos. 
A arte na moda - trata a arte como fonte de inspiração para desenvolver a criação na moda. A releitura de elementos artísticos clássicos, modernos, pós-modernos são transferidos para referendar o processo na criação de motivos têxteis ou expressar a silhueta de um determinado período - renascentista, barroco, rococó, elizabetano, vitoriano, eduardiano, belle-epoquiano. Essas releituras remetem ao estilo retrô, motivando a dinâmica na moda.

A moda-arte - tem como afirmação uma prática secular onde diversos movimentos artísticos estabelecem de forma aberta um novo canal para revelar a moda-arte. Dentre os movimentos de grande expressão identificam-se o estilo Glasgow (GrãBretanha), com destaque para um grupo feminino conhecido por Sister Studios; Arts and Crafts, movimento democrático artístico que deu visibilidade à produção industrial, exaltando a moda através de impressões com motivos e padronagens aplicados aos têxteis. Desde o início do Modernismo a condição moda-arte foi favorecida, associando-se a contribuição de expressões artísticas da Escola de Bauhaus, na formação de designers notáveis que canalizaram seus conhecimentos e interagiram com a moda de figurinos cênicos; as expressões artísticas Surrealista, a Wearable-Art, Op-Art, Pop-Art, entre outros movimentos que marcaram o citacionismo influenciando a moda contemporânea

Diversos criadores de moda desde a virada do século XX como Mariano Fortuny, Paul Poiret, Madeleine Vionnet, Elsa Schiaparelli trabalharam aspectos na estamparia e suas experimentações Ihes conferiram idéias inovadoras na moda; artistas modernistas como Sônia Delaunay, Giacomo Balla, Salvador Dali, também revelaram a arte na moda, uma conexão possível. Esta interface é uma prática secular e vários movimentos artísticos estabeleceram, de forma aberta, um novo canal de sinergia na moda-arte.

Abaixo, trecho de entrevista que João Braga concedeu à autora:

"Sonia Delauny é pouco conhecida, mas é de suma importância na arte-moda. Ela é tão importante quanto Chanel, mas ela é mais conhecida na moda e Sônia nas Artes Plásticas. Mas ao desenvolver "estampas simultâneas e vestidos simultâneos" (lei de contrastes de cores, como: laranja com laranja, roxo com verde) abre um novo caminho, um uso intenso na moda para a estamparia no séc XX( 
Poiret começou antes dela (estilo Fauve). Ela fez um importante desenvolvimento para o pessoal de Lyon, transmitiu um ar de tempo que fez no ano de 1920, quando ela aplica as leis científicas para serem jogadas na estamparia de moda. Inovou e empregava cores fortes. Aplicou estes conceitos dentro da difusão de moda e não da massa.Quando faz isso, atinge uma camada de intelectuais, formadores de opinão, mas de uma maneira atinge Moda, estampas geometrizadas, espírito Art-Decó". ${ }^{8}$

Em entrevista, a especialista em Design Têxtil Artemisia Caldas afirmou:

Sobre esta grande tendência e que está a cada dia mais forte, os designers de moda se apropriam da arte para fazer esta interferência na roupa, eu vejo com bons olhos. Principalmente, que arte é uma coisa bonita de se ver e aplicado na moda então, aí casa bem direitinho com a proposta do criador. $^{9}$

Como exemplo, Lino Vila Ventura e as diversas inspirações temáticas, num dos seus desfiles trabalhou com o pintor Austríaco HUNDERWASSER ( 15 de dezembro de 1928 , Viena; † 19 de fevereiro de 2000).

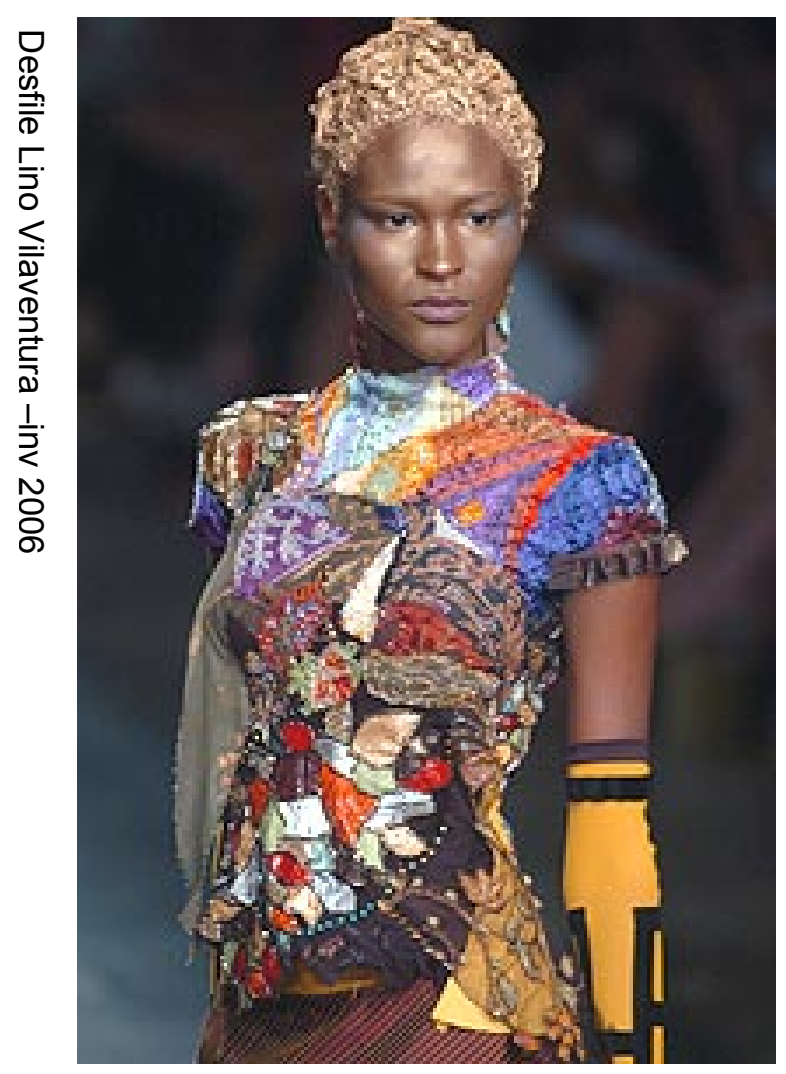

Esta relação com a Arte tem sido fonte de inspiração para o processo de criação, entre outras influências, que remetem à existência da vida. É o que propõe o artista austríaco Hundertwasser. 
Hundertwasser desenvolveu sua arte em duas dimensões fundamentais: a pintura e a arquitetura. Sua consciência de cidadão sensível o impulsionou a reagir contra a asfixia e a anemia da arquitetura funcional, racionalista, de superfícies retas e lisas. $\mathrm{O}$ artista considerou que a arquitetura moderna está doente, por isso é necessário curar. Hundertwasser, o pintor, se tornou "médico da arquitetura", remodelou edifícios, fábricas, casas, igrejas. Logo, a arquitetura renasceu com brilho, resplendor e magnetismo. Como um toque do rei Midas, tudo o que um verdadeiro artista toca se

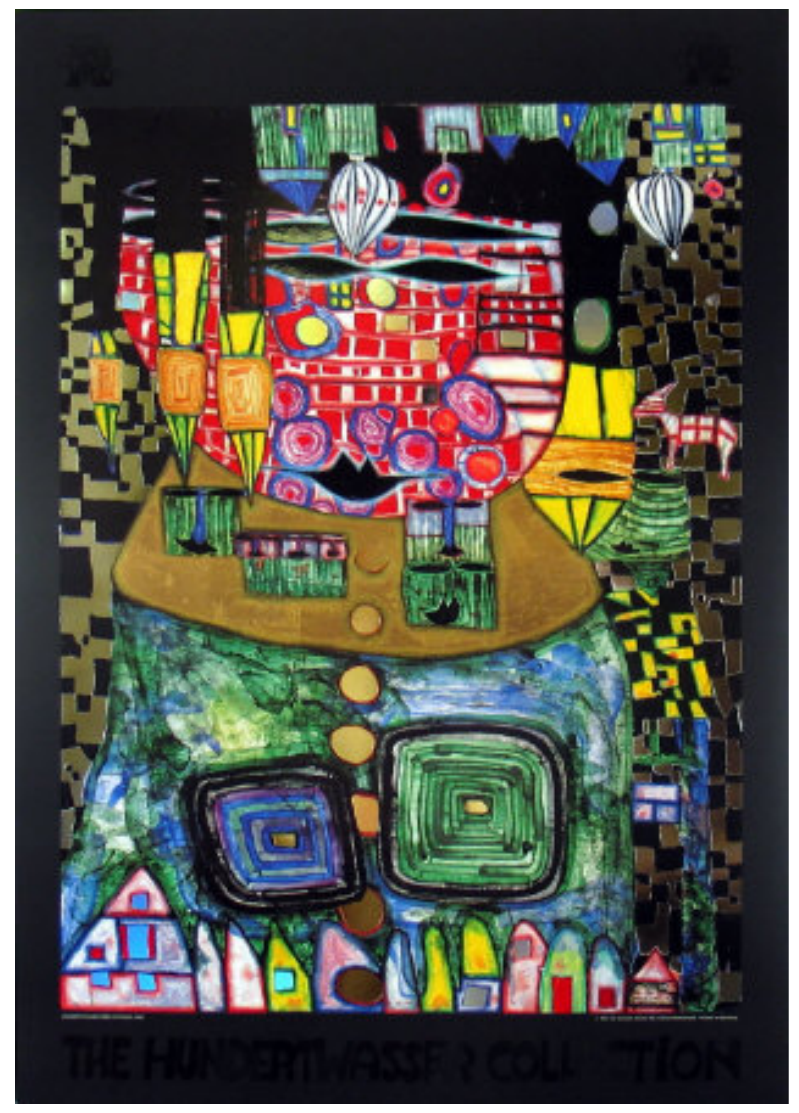
converte em ouro.

Hundertwasser foi um ativo artista alquimista.

Esta é também uma relação pertinente ao estilista como criador de formas e arquétipos que revela um estilo que se comunica com a visualidade tridimensional. $A$ criação da roupa se completa pela confecção do objeto e funciona como uma segunda pele. Assim, torna-se uma prática elaborar o objeto de moda agregando, além da função, uma linguagem estética. É também um procedimento recorrente na criatividade daqueles que atuam no sistema de moda da Alta Costura e do Prêt-àporter. Nestes segmentos ocorre visivelmente a comunicação estilística e artística através dos desfiles de moda contemporâneos quando exibidos nas passarelas, com o intuito de estabelecer a comunicação em forma de espetáculo, de contemplação e, com freqüência, revelam aspectos da arte performática, numa atitude que denota conceitos e envolve além do espetáculo outras categorias como a substância, a ciência, a estrutura e a afirmação. 
Regina Guerreiro, jornalista de moda, notifica o estilista de criador e transgressor e atribui o estilo sob a denominação de "Linografia"

Sobre Lino Vilaventura:

Lino é um profissional da moda brasileira,do estilo brasileiro,e contribui de maneira significativa para a elevação criativa,técnica e intelectual de um universo muitas vezes enquadrado no mundo das frivolidades .......Seus desfiles são ansiosamente aguardados ; e ele costuma nos decepcionar, pois ele sempre se supera....

Será então apropriado chamarmos Lino de estilista? Creio que não.Lino está além, não cria para atender a uma demanda da produção industrializada .Ele é um artista, um criador. O mais relevante de seu trabalho é a autenticidade de se reinventar sem perder referências e identidade próprias, melhor ainda, ser universal sem perder a brasilidade... Lino muda sem mudar, transforma sem transformar, repete sem ser repetitivo; e isso é ter estilo. ${ }^{10}$ João Braga pg. 7-A aventura de ser Lino Villaventura.

Para detalhar as conexões possíveis, seguem abaixo algumas delas:

- Elsa Schiaparelli (1890 - 1973) e Salvador Dali (1904 - 1989) formaram uma das mais incríveis parcerias desse bem-casado de moda e arte. O chapéusapato, o chapéu-lagosta, a bolsa-telefone, o vestido com estampa de moscas e o tailleur-escrivaninha, com bolsos em forma de gavetas, foram algumas das criações da dupla. Para esta estilista ainda Louis Argon e Elsa Triolet conceberam colares com comprimidos de aspirina.
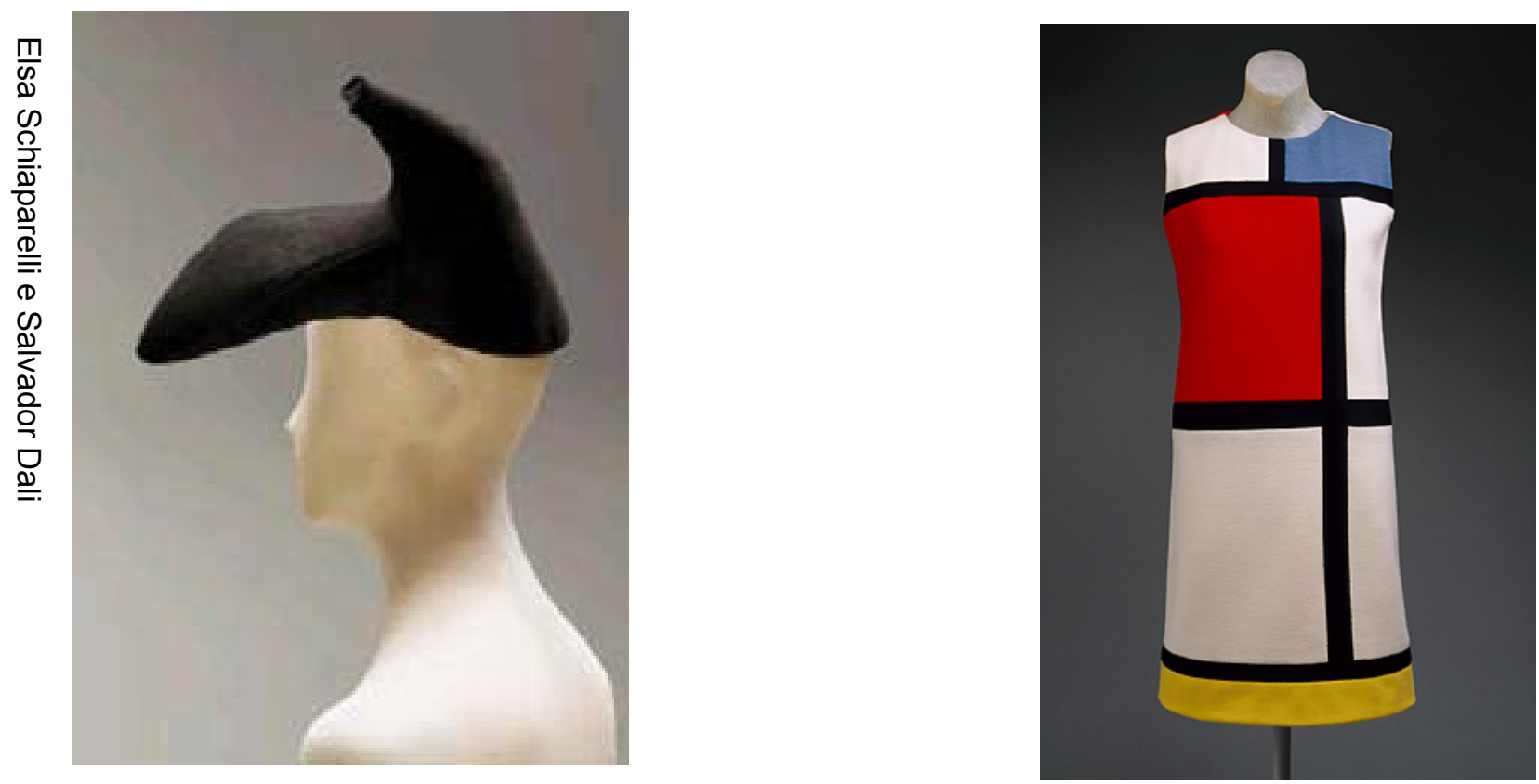
- Pacco Rabanne apresenta o primeiro desfile de manequins negras com materiais contemporâneos, malhas de metal e plástico fazendo referência aos móbiles de Julio le Parc. Pioneiro no campo de produções de roupas "nãousáveis" Rabanne rompe com a estética moderna, transpondo para o vestuário uma discussão atual nas artes plásticas, a do rompimento com o suporte tradicional, abrindo caminho para uma legião de criadores que se aventurariam no campo da pesquisa de materiais alternativos.

- Nos anos 80 e 90, Keith Haring cria convites e cenários para os desfiles de Vivienne Westwood.

- Pierre Cardin em 1986 com "Chaussures d'homme", referências de "La Modèle Rouge" de René Magritte, 1935.

- Com o vestido com referências de "tableau" (1921) de Mondrian; 1978 com vestido bordado da coleção de alta-costura com referência de "Profil au chapeau, 1961" de Pablo Picasso; 1988 utiliza o quadro "Plafond, Les Oiseaux" de Georges Braque e fez desenhos para a coleção Van Gogh, uma homenagem ao Cubismo.

- Jean-Charles de Castelbajac com o casaco "hommage à malevitch" com referência de Kasimir Malevich, "Cruz Preta, 20 anos de atraso". Em 1992, uma homenagem à beleza feminina usando a obra de Jean-Auguste Dominique Ingres "La source" (1856).

- Kenzo lança coleção em 1988 com referências de Henri Matisse "Figure décorative sur fond ornemental" e em 1992 lança casaco com referências ao quadro "Homme+Air+Espace" de Liubov Popova (1915).

- Jean Paul Gaultier usa "Suburban" (1969) de Richard Lindner em coleção de 1990.

Na concepção de Moura (2005), o design possui relações de proximidade e dialoga com a arte. Neste contexto "o processo de criação artística é a busca do novo, e não da novidade, de novas conexões, de novas formas de instaurar questões". É a necessidade de expressão constantemente renovada. Também é um processo de conhecimento, visto que compreende uma série de ações conectadas ao sujeito criativo, "que reflete, compreende, relaciona, elabora, ordena, classifica, transforma e cria" (CASTILHO; PRECIOSA, 2005). 
Dentro do tema arte e estamparia, outro trabalho pode ser citado. Trata-se de um estudo comparativo: Teatro Grego-Aristófanes, As Aves, com o Teatro dos Pássaros de Belém. realizado pela autora, orientado pelo Professor Clóvis Garcia. ${ }^{11}$

O Teatro dos Pássaros é realizado pela população do estado de Belém, e pode ser considerado também como um segmento da cultura popular, porque acontece sempre em junho, apareceu no século XIX e perdura até os nossos dias.

A obra do comediógrafo grego Aristófanes (Atenas, 450 a.C.- 385 a.C.) é uma dramaturgia que ressalta o naturalismo das relações sociais imersa a um humor satírico. Apesar das muitas diferenças que se apresentam entre estas duas manifestações artísticas, desde sua época até suas palavras, as aves que os centralizam ainda reservam outras analogias.

O Teatro dos Pássaros de Belém tem um figurino característico, que mesmo mudando a cada ano ainda mantém uma singularidade que faz com que o espectador reconheça cada personagem.

Este espetáculo é composto por compositores, diretores, atores e dramaturgos moradores da região, em caráter de tradição, já que os donos dos grupos geralmente passam os mesmos aos seus sucessores familiares. Vários componentes são apresentados, como a dança, o canto, o drama, a comédia e a música.

Os Pássaros, uma obra que tem como personagens centrais pássaros, fadas, índios, caçador, feiticeiras, e como cenários castelos, fazendas e florestas. Dentro destas situações dramáticas se aplicam as variações estilísticas mencionadas acima.

Este teatro popular tem como enredo principal a morte e ressurreição de uma ave sagrada para determinado grupo, por um caçador ou passarinheiro. Possui também forte apelo moral, distinguindo o que é bom e o que é mal através do julgamento, castigo e perdão. Confeccionado em linguagem simples e direta, as palavras 
utilizadas são bastante comuns e pouco refinadas, não há uma preocupação com a concordância lingüística em si. E é o conjunto de todos os elementos que determinam a consistência lúdica do espetáculo, portanto tudo que nele há desempenha um papel essencial para sua compreensão.

O Teatro dos Pássaros é dividido por dois segmentos e existe uma diferença significativa no modo de apresentação destes grupos:

- Pássaro Junino ou Pássaro Melodrama, constituído de grupos como: Bem-te-vi, Papagaio Real, Rouxinol, Sabiá, Tem-Tem, e Tucano.

Este grupo tem uma noção artística mais elitizada, porque carrega referências diretas dos grupos teatrais internacionais que se apresentavam nos grandes teatros de Belém, no começo do século XX. Época da economia da borracha, onde ocorreu grande efervescência não só econômica, como política e cultural.

O enredo, além de contar a história básica dos cordões de bichos e pássaros, ou seja a morte e ressurreição do pássaro, diferencia-se destes porque nos Pássaros Juninos, o pássaro geralmente não morre, e sim é ferido, alvejado ou capturado. A história é aquela que narra a vida dos nobres, o figurino é luxuoso.

- Cordão dos Pássaros, constituídos por grupos como: Arara, Colibri, Tangará. O cenário das histórias é sempre a floresta Amazônica com seus encantamentos e lendas. Muitos desses mistérios devem-se à imaginação dos caboclos ribeirinhos que, diante da eterna insegurança para enfrentar o desafio pela sobrevivência frente a natureza exuberante, formada por rios e florestas, cria mitos e lendas sobre os vários olhares sempre alertas e prontos ao ataque.

A diferença mais explícita entre o Pássaro Junino e o Cordão dos Pássaros é a estrutura de representação. No cordão, herança dos cordões de bichos amazônicos vindos do interior, os brincantes entram no palco e ficam organizados sempre em meia lua. As cenas se passam bem no meio e o pássaro é o personagem central. Já no Pássaro Junino, de origem mais urbana, todos os elementos são mais bem 
elaborados, do figurino ao texto. Abrem-se e fecham-se as cortinas, os brincantes trocam duas ou três vezes de vestimentas e o pássaro é quase um coadjuvante.

Para o desenvolvimento da estampa pensou-se em uma base de tecido que figure tanto aos feitos humanos, pintura e cerâmica envelhecida pelo tempo, quanto à iconografia das aves. As estampas remetem à pintura e cerâmica gregas, com imagens de cenas de músicos e faixas decorativas feitas com a função de agradar ao espectador. Esta função é parte da arte retórica que surgiu na Grécia e Roma.

Quanto à iconografia das aves, buscou-se uma aproximação da paleta de cores das penas de aves encontradas no Brasil tropicalista, indicando uma perspectiva para o advento de uma nova sociedade, visualizada pelo autor em sua época, como a "cidade das aves".

\section{As Aves de Aristófanes}

A peça "As Aves" (414 a.C.), escrita pelo comediógrafo conta a história de dois demagogos (Pistêtairo e Euelpides) que partem em busca de Tereu (o homem que se tornou pássaro), a fim de fundar uma cidade nas nuvens. Pistêtairo convence Polpa (Tereu) da soberania das aves sobre os homens e os deuses e da importância da criação de uma cidade que os mantivessem como no princípio dos tempos. JO pássaro acha uma idéia genial e convoca toda a passarada para executar o plano, no início há um grande tumulto entre eles, mas logo são convencidos de que é um plano infalível. Liderados pelo demagogo (que ganha asas dos pássaros), criam simultaneamente um projeto de conquista (as aves dominariam os deuses e os homens) e um projeto que poderia chamar de propagandístico (este domínio está baseado na demonstração da superioridade e eficiência das aves).

Aristófanes explora a linguagem comum, nomes e "apelidos" de personagens conhecidos, mitos, literatura, provérbios, conhecimentos específicos de geografia e sobre a vida das aves. Utiliza-se de todos os argumentos que tragam comicidade e semelhança entre deuses, aves e homens. Assim torna-se extremamente cômico, pois satiriza o uso indiscriminado de argumentos e informações pelos sofistas. 
Para a definição dos perfis das personagens elaborou-se uma classificação das personagens que estão distintas pela determinação de uma categoria.

Categoria I - Humanos que foram transformados em aves e passaram a compor a cidade das aves.

Categoria II - Aves

Categoria III -Humanos habitantes de Atenas.

A comédia mostra duas preocupações básicas: fazer o público rir e criticar as instituições; políticas e intelectuais da Atenas desta época. Todos os recursos cômicos imagináveis foram usados, desde a sátira mais grotesca até a malícia mais sutil: situações ridículas, cenas fantásticas, personagens alegóricos, caricaturas de personagens humanos reais e deuses, pilhérias, ironias, jogo de palavras, trocadilhos, mal-entendidos, exageros, substituição de palavras esperadas por outras inesperadas, paródias, neologismos e provérbios.

À priori, ao comparar o Teatro dos Pássaros com a obra de Aristófanes, não se encontra tantas analogias aparentes. Porém fazendo uma análise mais aprofundada entre estas duas manifestações artísticas é possível encontrar relações muito prolixas e complexas. A primeira delas está caracterizada em seu conteúdo expressivo, onde tanto o Teatro dos Pássaros, como a obra "As Aves" carregam em si uma trama de críticas à sociedade vigente (seja aos gregos antigos ou aos problemas ontológicos).

O Pistêtairo de Aristófanes quer ter uma cidade ideal projetada a partir daquilo que o seu autor condena, já o caçador que aparece nos Pássaros é conduzido a uma situação, seja por encantamento ou por necessidade, que a moral da história condena para dela desprender-se e mostrar o lado certo do drama. Este apelo moral que permeia as duas obras mostra-se de maneira bem distinta entre Aristófanes e o Teatro dos Pássaros, mas de qualquer maneira estão lá.

Com relação aos figurinos tanto os da montagem da Escola Livre de Teatro como do Pássaro são essenciais para o bom entendimento dos espetáculos. No caso do primeiro, respeitando os movimentos e caracterizando cada personagem, e no caso 
do segundo, desempenhando a mesma função, mas aproveitando a corporalidade do ator.

Outro fator muito interessante é o "timing" da ironia que em ambas as peças transitam entre o drama e a comédia, a fim de propor uma dinâmica mais concisa ao espectador. O Teatro dos Pássaros, claro, trata de uma linguagem muito mais simplificada que a erudição de Aristófanes, portanto esta ironia assemelha-se mais ao "pastelão".

A pesquisa, que trata do mundo onírico do folclore e da mitologia, através de um corte tão distante no tempo, também o aproxima por tratar-se de temáticas humanas que em sua essência mantém esta inquietação de poder, glória e redenção.

A estamparia desenvolvida, como pode ser visto na reprodução abaixo, buscou um diálogo entre as duas peças teatrais e também o contraste de estilos, dando um equilíbrio de formas e cores.
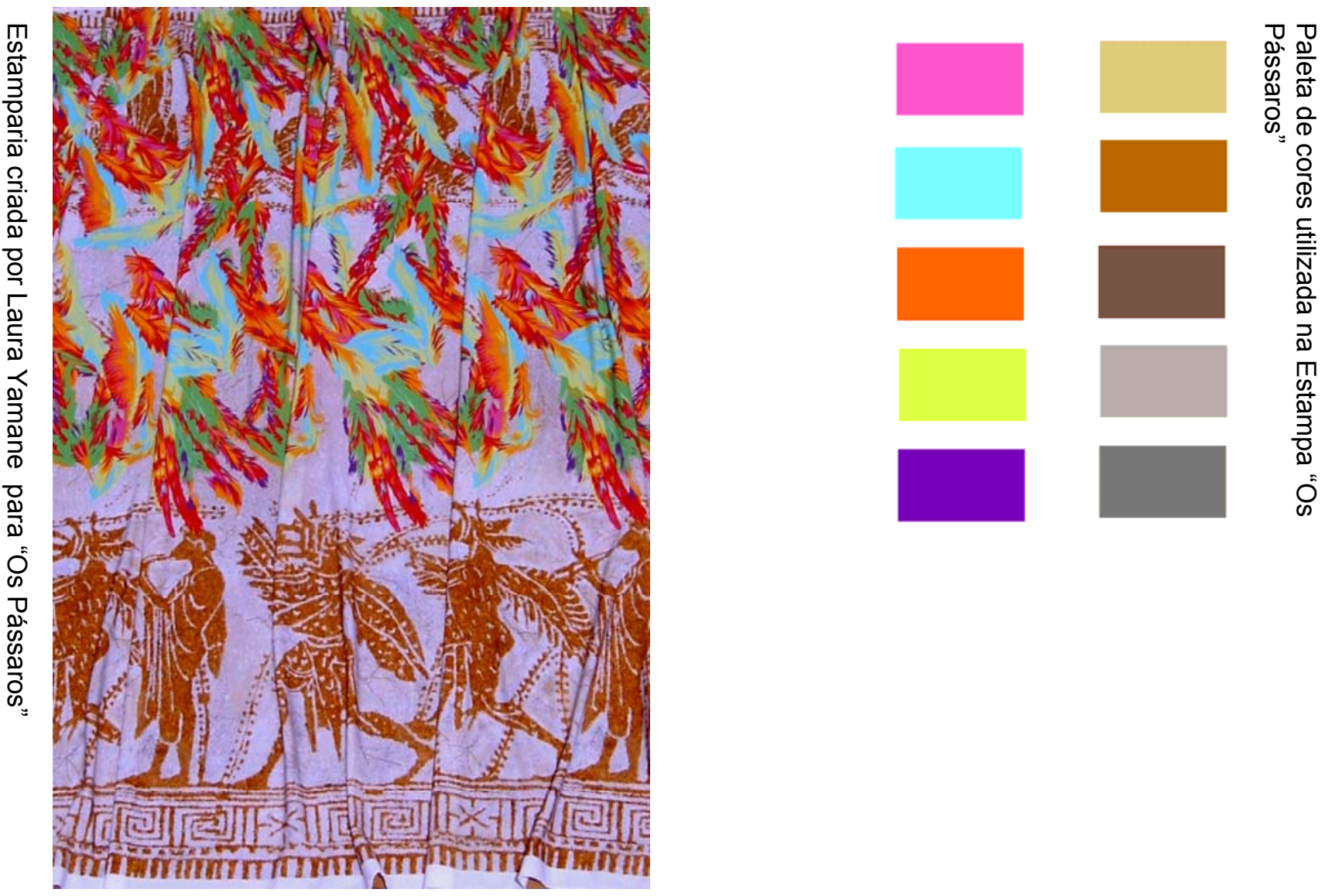
Dados técnicos da estampa criada para o trabalho:

Tecido Padrão: Estampado em malha $-90 \%$ poliamida e $10 \%$ elastano - criação de estampa - Laura Yamane.

Cartela de cores: estampado colorido - Pink, turquesa, laranja, limão, roxo e vermelho e tons terrosos - cáqui, terra cota, café, cinza claro e chumbo

Para esta categoria foi escolhida uma base de tecido de malha muito atual, $100 \%$ poliamida, e que pode servir para confeccionar uma Linha de roupas para a Praia, especialmente para Exportação.

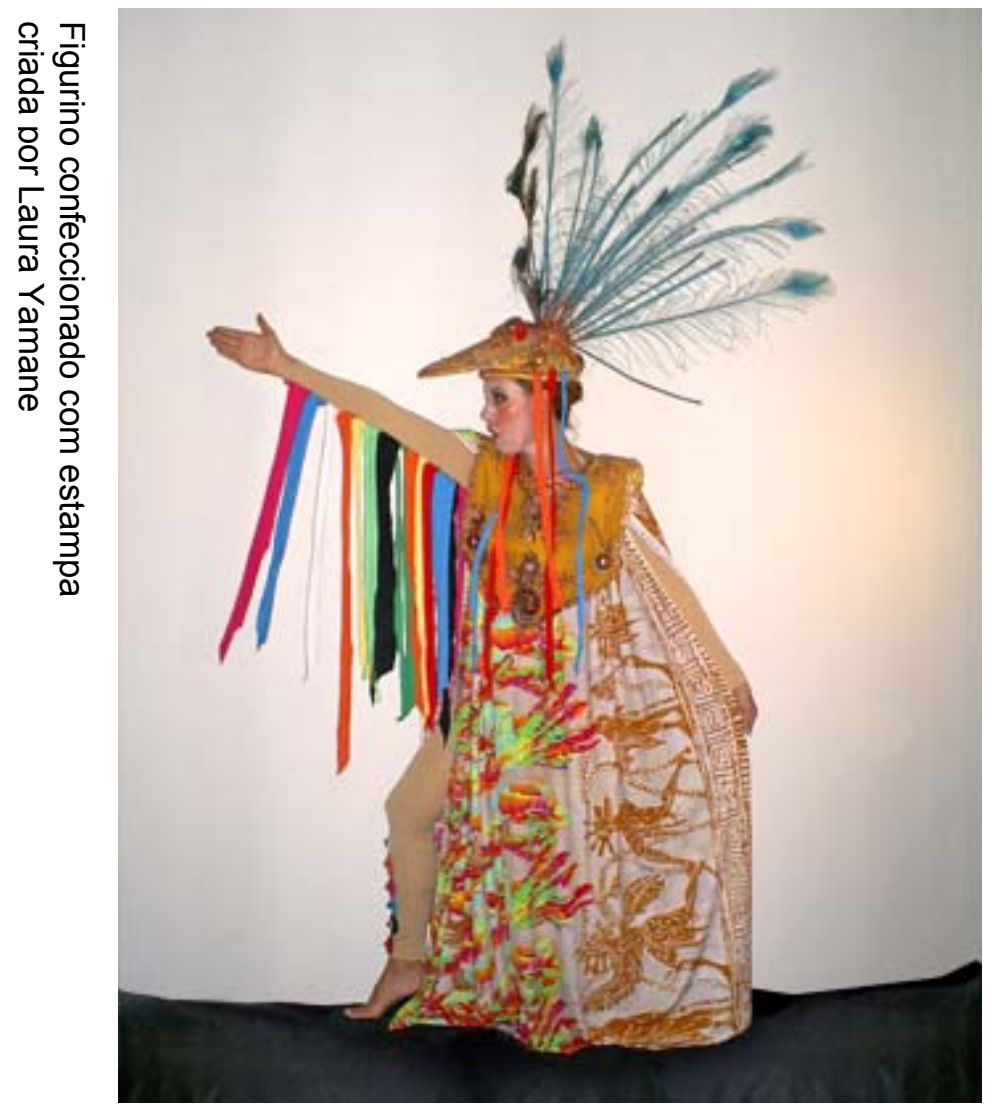

O que influenciou no processo de criação desta estamparia foi 0 acesso ao livro de Aristófanes, As Aves, que propôs uma volta no tempo, passando pela Grécia e Roma, evocando tons terrosos, vendo as pinturas das paredes de um Teatro ao ar livre.

$\mathrm{Na}$ parte de baixo do tecido, na barra, a opção foi por algo que figure aos feitos humanos, como pintura e cerâmica envelhecida pelo tempo, com imagens de músicos e faixas decorativas gregas.

A volta ao presente, para inserir o Teatro dos Pássaros de Belém, se deu ouvindo músicas brasileiras, e para a estampa se tornar alegre e com energia, foi desenhada uma revoada de pássaros, como se estivesse voando e dançando ao som do coro. A paleta de cores buscou cores encontradas em nossas matas, nossos rios, nossas flores, que são as cores das penas de nossos pássaros. As formas e cores usadas são contrastantes. 
O projeto e realização da estamparia para a obra clássica teatral "As aves" do comediógrafo grego Aristófanes (Atenas, 450 a.C-385 a.C.), e o Teatro dos Pássaros de Belém foram concebidos a partir de uma releitura que trata metaforicamente de algumas questões sociais, éticas, políticas da sociedade grega "antiga" e a projeção de tais questões na sociedade atual, mais especificamente, a sociedade brasileira.

E segundo Margaret Refkalefskyt: "ou por mais inacreditável que ela possa parecer à semelhança do que acontecia a tragédia na Grécia Antiga." (pg. 49). Isto porque nestas construções narrativas pode-se devanear entre a realidade, a ficção e o mito. Assim como fez Aristófanes em "As Aves". 
${ }^{1}$ Cf. Frank Whitford, Bauhaus, cit. p.12

2 John Gage, color and culture: Practice and Meaning from Antiquity to Abstraction (Berkely/Los Angeles: University of California press, 1993), pg.260.

${ }^{3}$ JOHANNES Itten, design and form:the Basic Course at the Bauhaus,cit.p.10

${ }^{4}$ Esclarece o historiador da arte Michael Baumgartner à Swissinfo.

${ }^{5}$ Aragan no livro Processo Criativo - pg.46

${ }^{6}$ Aragan no livro Processo Criativo - pg.47

${ }^{7}$ Swissinfo, Rafaella Rosselo - Tradução de Fabiana Macchi.

${ }^{8}$ João Braga, estilista e professor titular na área dos livros da História da Moda concedeu entrevista à autora no dia 30/05/2008.

${ }^{9}$ Artemisia Caldas - Especialista em Design Têxtil, professora do Curso de Design de Moda da Faculdade Católica do Ceará - Marista concedeu entrevista à autora em Maio/2008.

10 João Braga pg. 7-A aventura de ser Lino Villaventura.

${ }^{11}$ Trabalho de conclusão do curso "Aproveitamento do Folclore na Literatura Dramática Brasileira" sob a orientação do Prof. Clóvis Garcia. Um estudo comparativo: Teatro Grego Aristofanes, As Aves, com o Teatro dos Pássaros de Belém. 


\section{PROCESSOS DE ESTAMPARIA}

Este capítulo abordará processos de estamparia existentes de maneira detalhada, enfocando a artesanal e a industrial, com cilindro e quadros e digital.

\subsection{Manual}

Seqüência para estampar (estamparia a Quadros Manual)

- Coloca-se o tecido na mesa;

- O quadro é colocado no tecido;

- Espalha-se pasta colorida no tinteiro do quadro;

- Movimenta-se a rasqueta até o lado oposto do tinteiro, exercendo uma leve pressão sobre o quadro;

- Os movimentos de rasqueta forçam a saída da pasta colorida pela área obstruída da tela, imprimindo assim o tecido.

Na estamparia manual a quadros pode-se estampar até 2000 metros por dia.
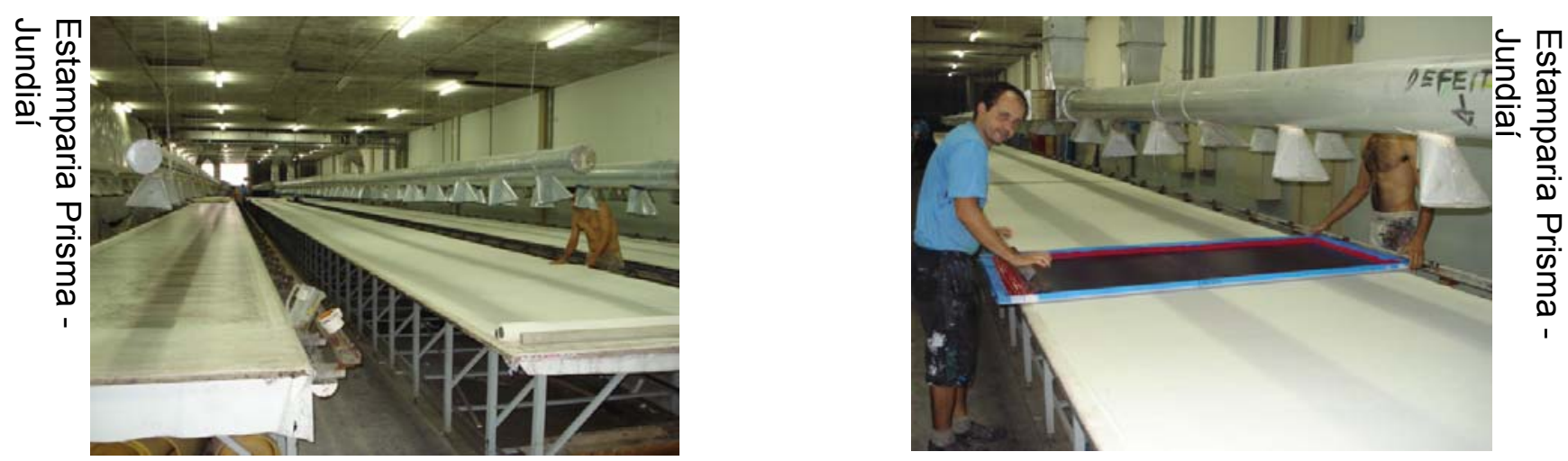

\subsection{Industrial}

\subsubsection{Cilindro e Quadros}




\section{Estamparia a quadros automáticos}

O tecido se locomove transportado por uma esteira sem fim que se movimenta, sincronizadamente, com os quadros.

Sobre uma esteira, existe um campo magnético que também age em sincronia com a esteira, pois assim que os quadros se sobrepõem ao tecido, o campo magnético é acionado ,fazendo a barra de impressão se deslocar da direita para a esquerda e vice-versa ,na reportagem seguinte.

A alimentação dos quadros com pasta é feita manualmente. A secagem é feita através de secadores próprios.
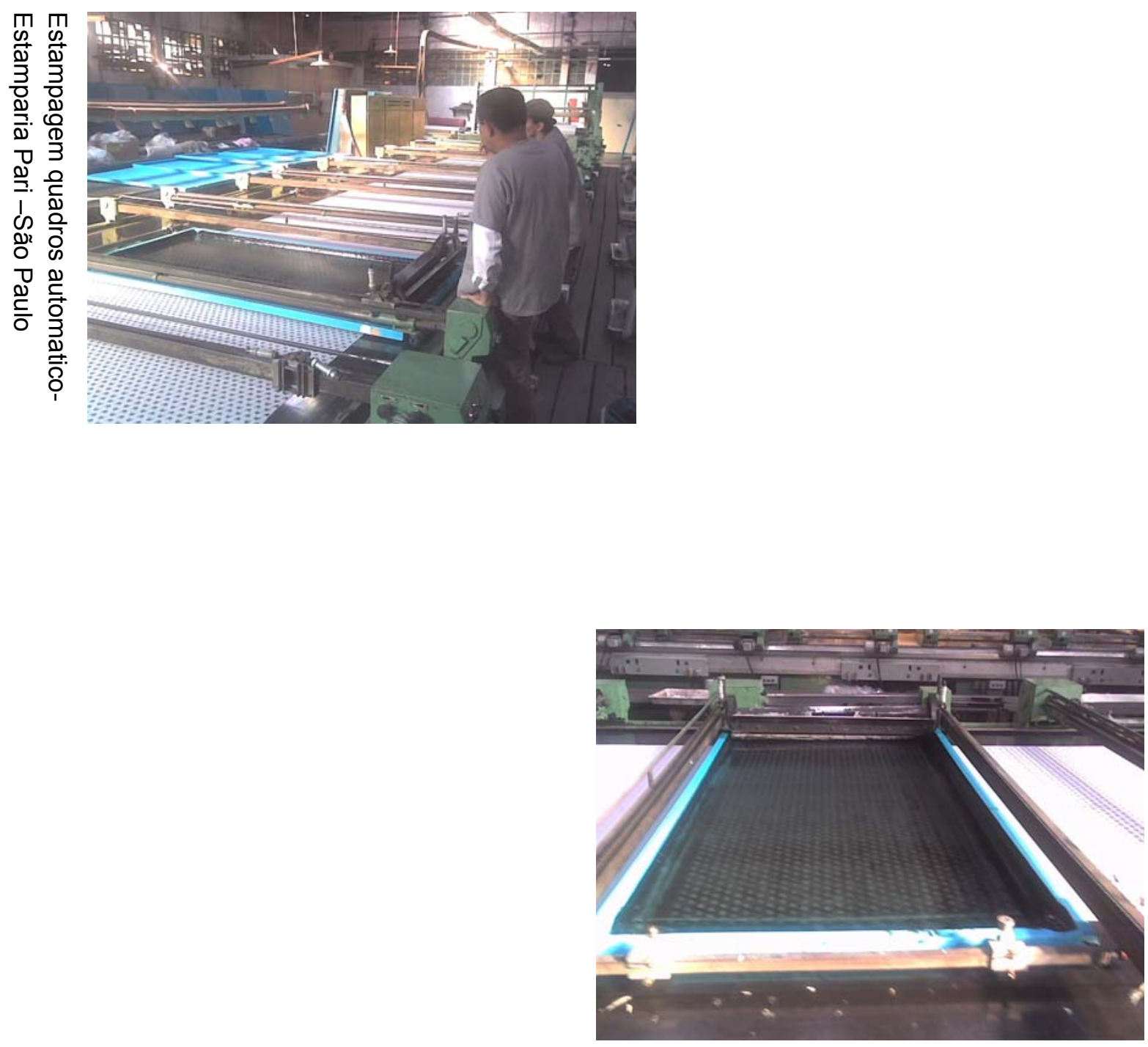
O tipo de Quadro automático é igual ao Artesanal. A diferença entre eles é que:

- Automático $\rightarrow$ o quadro é fixo e o tecido vai se movendo através de um tapete, à medida que estampa, o quadro levanta e assim sucessivamente. Pode-se estampar até 80 metros por minuto.

- Artesanal $\rightarrow 0$ tecido é fixo, através de dois operários que seguram nos lados do quadro vai estampando e movendo os quadros.

Em entrevista para a autora, Luis Augusto Conté (gerente de desenvolvimento da Estamparia Salotex), explica:

O processo de estamparia a quadro que também pode ser chamada de estamparia plana. Seja ela artesanal ou automatizada têm algumas vantagens em relação à rotativa. Uma delas é a precisão de encaixe no registro do desenho. Por exemplo: Os desenhos com motivos de gravataria estampados em seda pura com filetes na espessura de um fio de cabelo são estampados a quadro manual. Outra vantagem na estamparia artesanal é que ela pode ser montada por um preço extremamente baixo em relação a aquisição de uma máquina rotativa, além de não exigir grandes instalações. Também pode-se dizer que o rapport de um desenho a quadro é muito maior que o do cilindro, como por exemplo desenhos de toalha de mesa.

\section{Estamparia cilindro}

\section{Como estampar em cilindros}

- Os cilindros são montados num tapete sobre o qual se coloca o tecido a ser impresso. A pasta e a rasqueta são colocados dentro dos cilindros.

- Os cilindros ficam em contato com o tecido. A rasqueta (interior do cilindro) é puxada ao encontro do tapete por um campo eletromagnético.

- Quando a máquina é acionada, o tapete se desloca e os cilindros adquirem um movimento de rotação.

- A rasqueta força a saída da pasta colorida e imprime o tecido.

- Os cilindros são colocados em horizontal sobre um tapete 
- O número de cilindros (de cores) varia de uma a dez cores, sendo que cada cilindro corresponde a uma cor.

- Os cilindros precisam ser ajustados para que o desenho encaixe um no outro.

Na estamparia de cilindros pode-se estampar até $60 \mathrm{~m}$ de tecido por minuto.
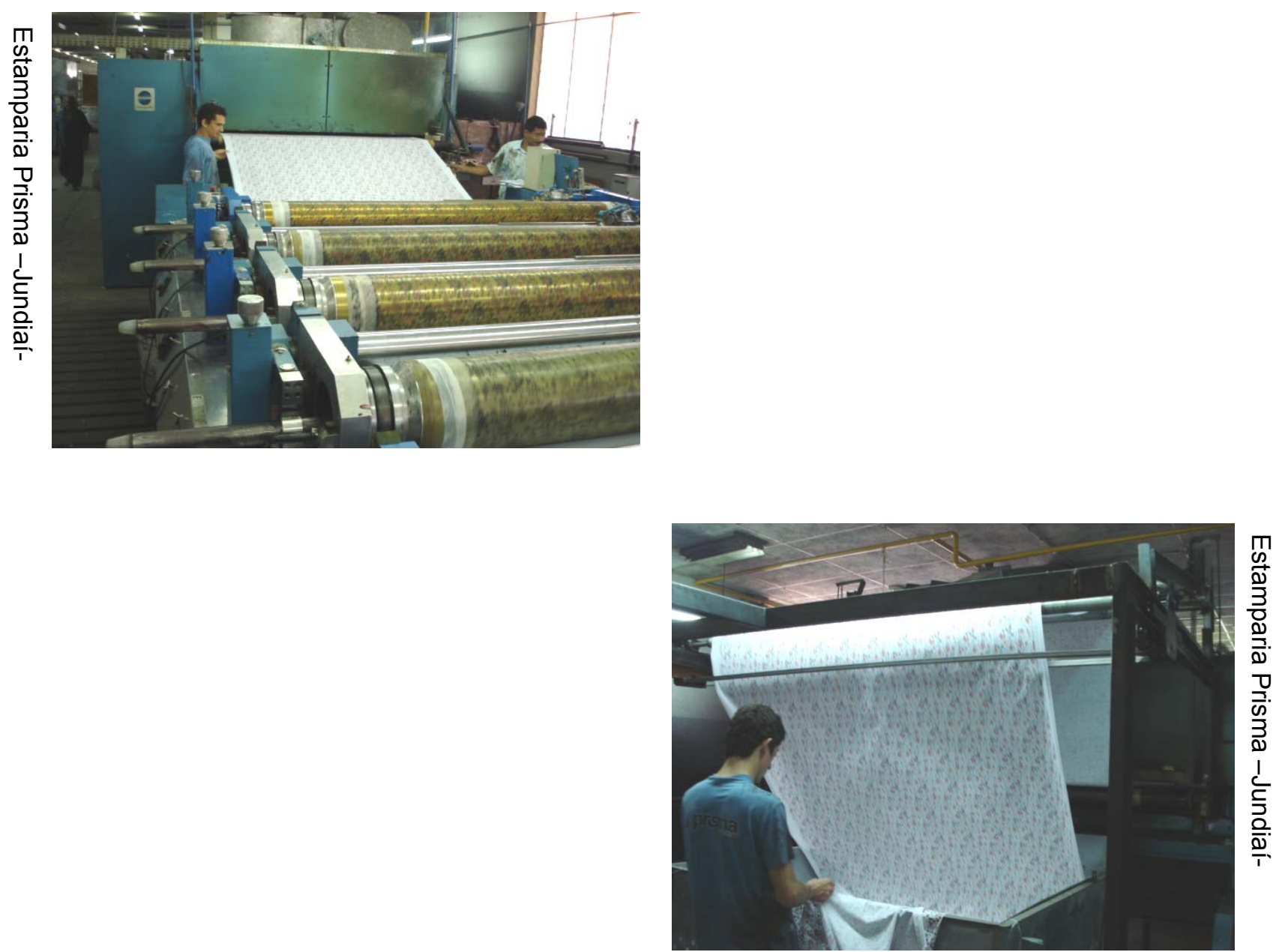

A seguir, descrição das vantagens dos cilindros sobre os quadros:

- Maior velocidade para estampar, como conseqüência, maior metragem por dia ( custo $\mathrm{x}$ benefício )

- Pode-se estampar listras contínuas, isto é, no sentido do urdimento.

Trama: transversal

Urdume: longitudinal. 
Permite áreas contínuas chapadas de tinta, como pois (estampa de bolas), impossível de ser feito no quadro, pois haverá marcação de tinta quando o quadro for movido.

Quanto ao cilindro ele estampa numa rapidez incomparável que pode chegar a quatro vezes mais que a plana automatizada. Outra vantagem é que não exige tantas pessoas envolvidas durante o processo. Também o tecido já sai seco e imediatamente é encaminhado para lavagem ou vaporização. Pode-se estampar também desenhos com fundo cheio sem se preocupar com remontes da atacadura. Cilindros também são mais resistentes por serem fabricados em metal. LUIS AUGUSTO CONTÉ (gerente de desenvolvimento da Estamparia Salotex. São Paulo).

\section{PROCESSOS DE ESTAMPARIA}

1. Estampar

2. Secar

3. Polimerizar a $150^{\circ}$ durante 3 minutos.

4. Foulardar

5. Secar

6. Polimerizar.

\subsubsection{Estamparia Transfer-Paper}

Segundo Phellipe Chiesi, diretor da Estamparia Sublispaper, transfer é a transferência de uma película de tinta seca impressa sobre um substrato para tecido. Dessa forma, o processo de transfer envolve duas etapas: a primeira consiste na estampagem do produto sobre um papel especial. O papel é estampado somente com cilindros, com um corante específico para o papel. A segunda etapa consiste na posterior transferência deste papel para o tecido através de cilindro de aço, em cujo interior há um óleo aquecido a 260 graus.

O tecido e o papel passam entre um feltro e o cilindro aquecido, como um sanduíche.

Após estas operações o produto já está pronto para ser entregue ao cliente. 

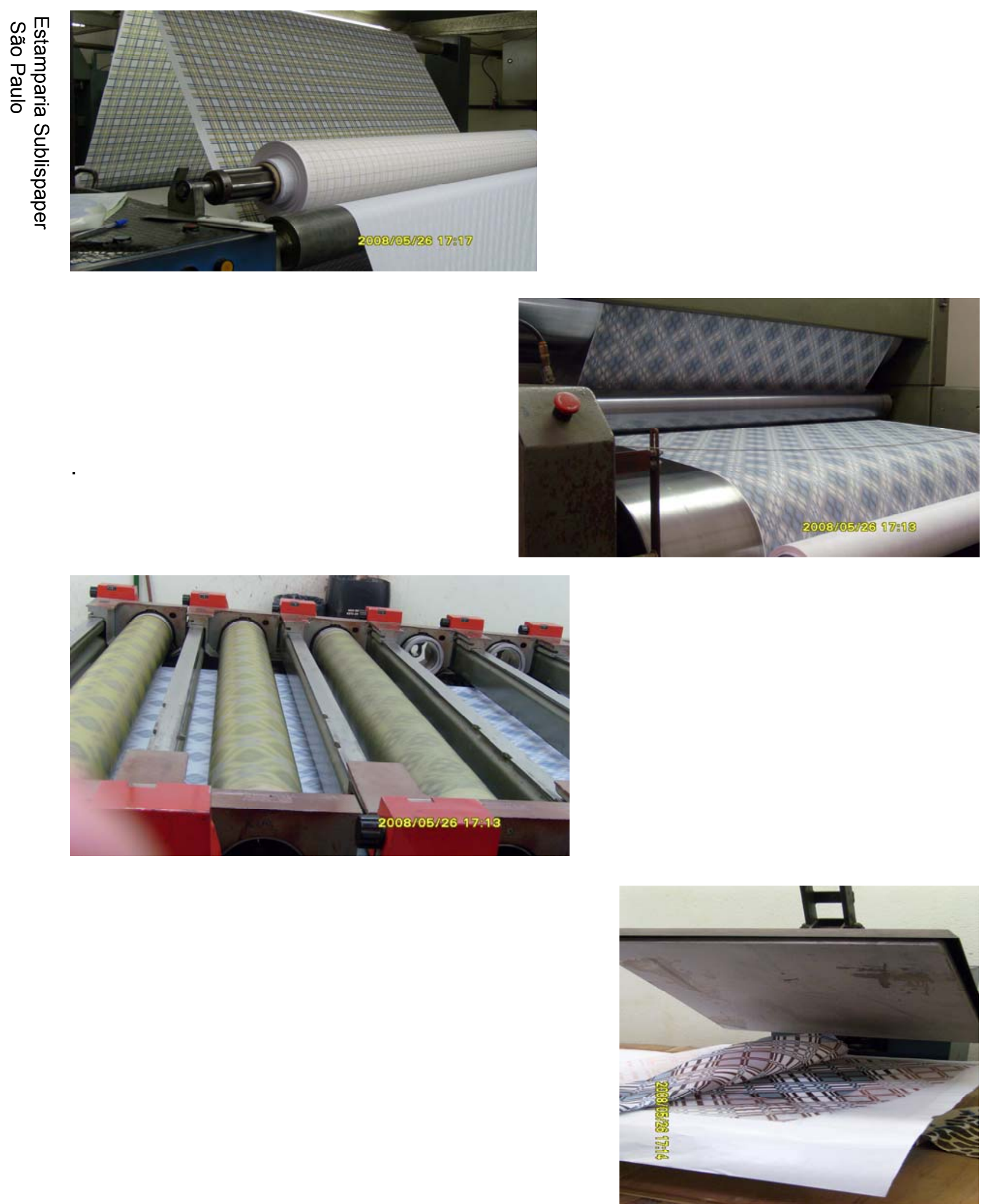

É recomendável sempre fazer testes antes, pois cada tipo de tecido tem composição diferente e pode acarretar diferença de cor, tempo e temperatura de transferência. O tecido mais adequado para ser transferido do papel é o $100 \%$ 
poliéster, $100 \%$ poliamida. Nos tecidos naturais como 100\% algodão,100\% linho , não há solidez de cores, o efeito também fica com aspecto desbotado.

O processo de transfer é também um suporte para o mercado de produtos para estamparia localizada, que vem se desenvolvendo cada vez mais e ampliando a sua lista de produtos e aplicações.

A vantagem de se trabalhar com transfer é que se consegue uma produção rápida para grande quantidade de estampas ou aplicações.

\subsubsection{Estamparia Digital}

O termo digital surgiu pelo fato de que as imagens são desenvolvidas e enviadas para a gravação/ impressão através de softwares que as digitalizam.

O desenvolvimento do desenho (estampa) pode ser idealizado através de diversos softwares gráficos, como por exemplo: Adobe Photoshop, Adobe lllustrator, CorelDraw, Tex-Design, Pixelarte. Nesses softwares, são criados os os desenhos de estamparia, rapports, resoluções etc.

Quando é feito o desenho de estamparia para o processo digital, não há necessidade de separar cores como acontece com cilindros e quadros.

Após a conclusão do desenvolvimento do desenho, o arquivo é salvo ou exportado para o formato bitmap em alta resolução (300dpi) para que possa ser impresso.

A impressão da estampa pode ser realizada através de Gerenciadores de Impressão (RIPS), adquiridos na maioria das vezes com o próprio equipamento digital. Alguns

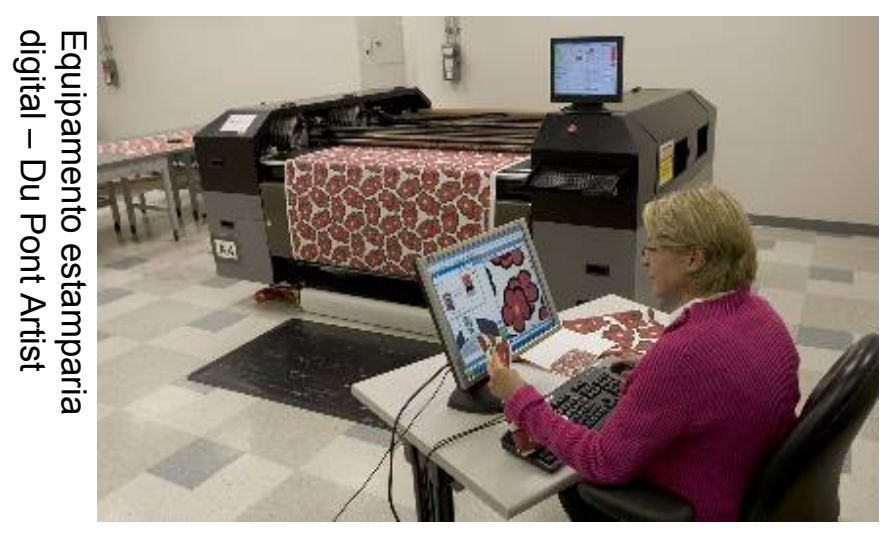
RIPS fazem a leitura de diversos tipos de arquivos bitmaps como TIF, JPG, EPS, PSD etc.

Os fornecedores de tecnologia têm desenvolvido programas e equipamentos digitais que são usados para desenvolvimento de produtos 
(concepção), modificação e transferência dos desenhos (motivos), em arquivos.

O desenvolvimento de tecnologias digitais é um importante caminho para satisfazer as necessidades dos clientes e do mercado. Em um mercado cada vez mais globalizado, onde a moda e o comportamento ajudam a ditar o ritmo das inovações, os consumidores exigem a comercialização de artigos com uma grande variedade de cores e desenhos (motivos). Isso faz com que haja necessidade de um sistema de produção com um alto grau de adaptabilidade e flexibilidade.
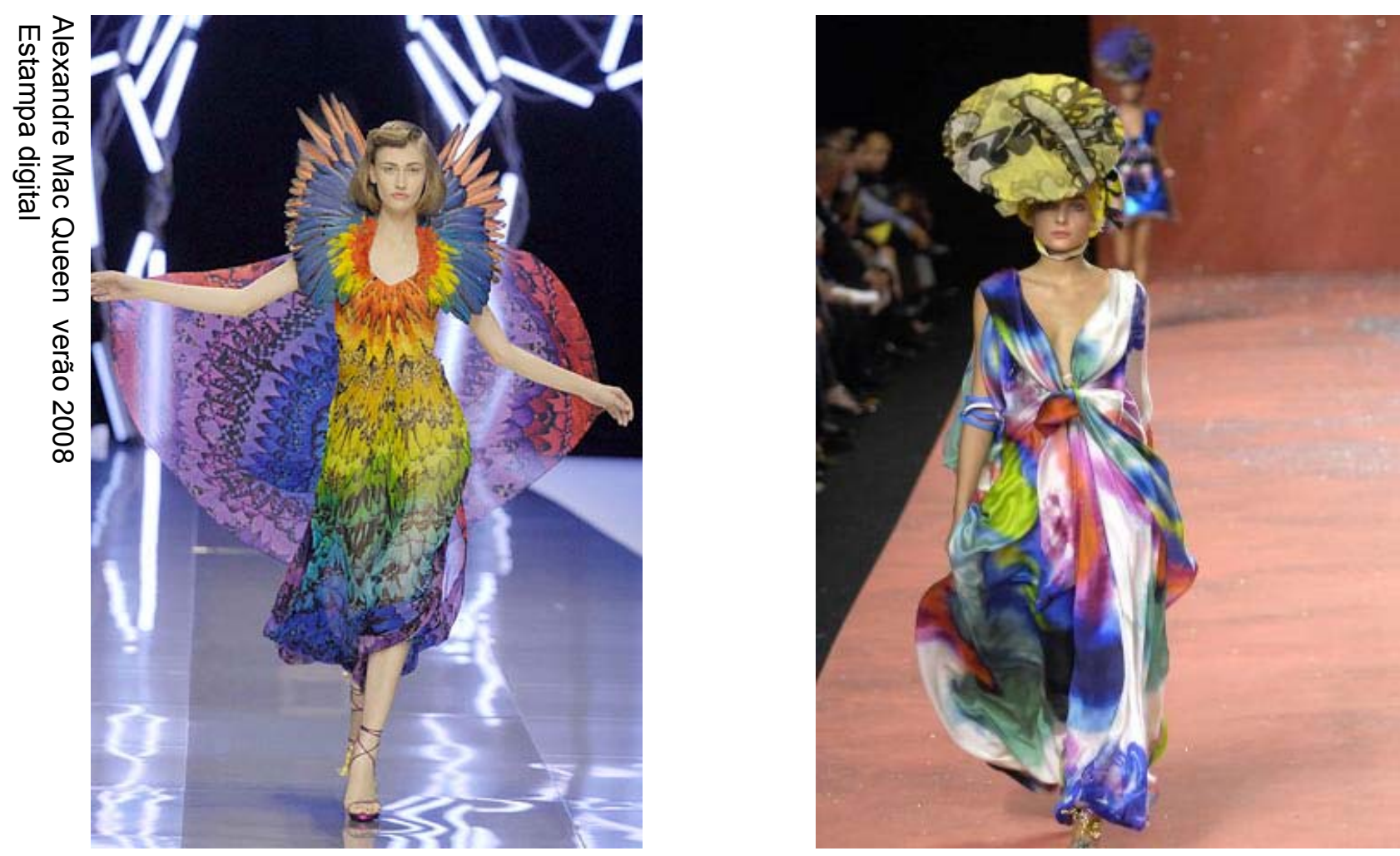

O desenvolvimento dessa tecnologia visa a atender uma tendência de mercado, que é a demanda por pequenos lotes de produção e grande variedade de desenhos, cores e formas. Logo, pode-se afirmar que o desenvolvimento desta tecnologia fará com que a cadeia de suprimento do elo de confecção esteja apta a produzir de forma customizada.A tecnologia de estamparia digital é utilizada para desenvolver e produzir amostras, estampas individuais (design exclusivo) e produções em tamanhos diferenciados.

Com isso diminui-se um dos grandes gastos do processo de estamparia, que é a gravação de telas ou cilindros, visto que o desenvolvimento de um produto pode ser enviado diretamente para a estação de estampagem, sendo que outra grande 
vantagem dos sistemas de estamparia digital em relação ao sistema tradicional é a minimização de custo.

O processo de estamparia tradicional se caracteriza por um elevado custo na instalação e dos equipamentos, o que faz com que somente grandes produções baixem os custos. Para pagar a produção em um sistema tradicional de estamparia são necessários cerca de 500 metros de tecido estampado. Nos sistemas de estamparia com tecnologias digitais deve-se considerar que o custo é constante, independente da metragem estampada.
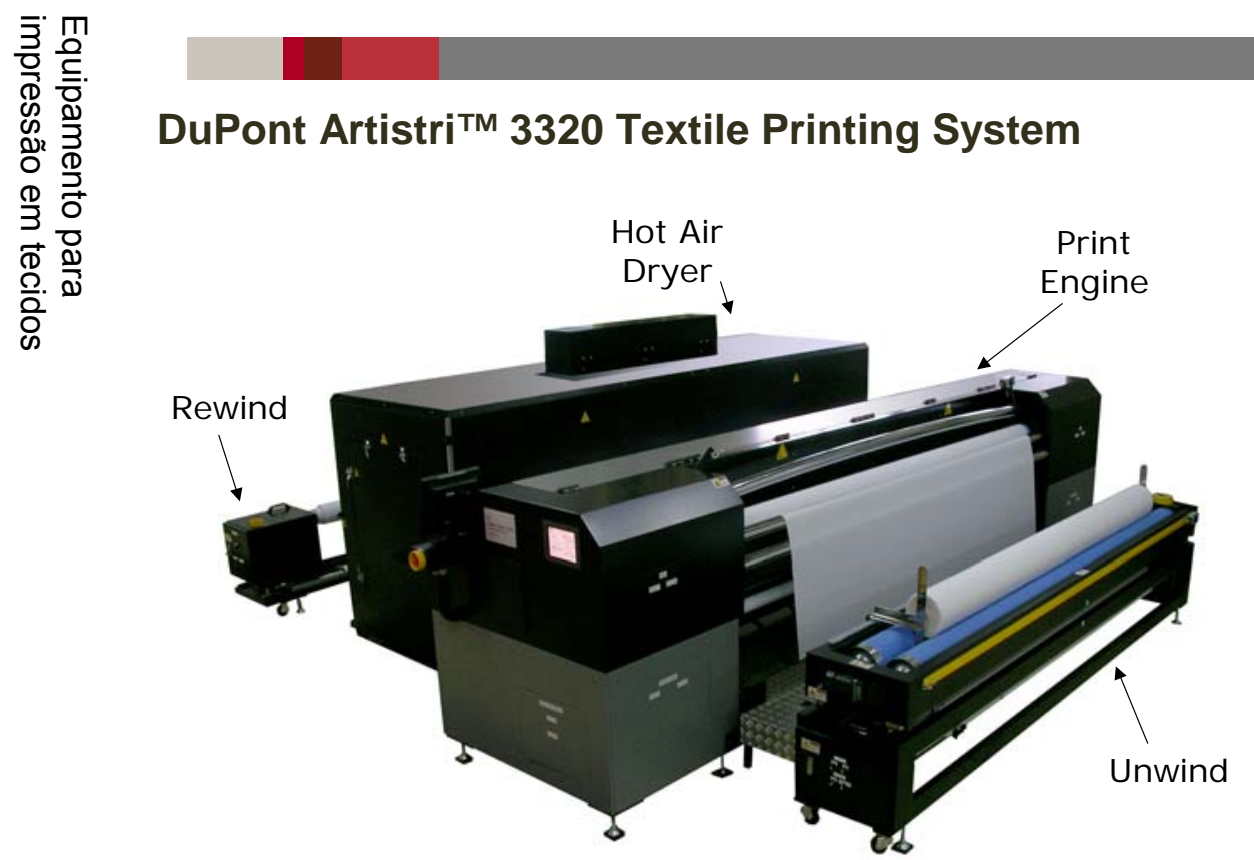

Nos sistemas de estamparia com tecnologias digitais deve-se considerar que o custo é constante, independente da metragem estampada. Porém, como essa tecnologia encontra-se em fase de desenvolvimento industrial, existem alguns pontos a serem desenvolvidos, tais como a gama de cores na reprodução de uma imagem.

O uso de cores primárias - ciano, magenta, amarelo e preto (CMYK) - funciona apenas com alguns fornecedores como HP, Epson, Minari, Lexmark, segundo Sr. José Macedo, presidente da Sintequímica e agente da máquina de estamparia digital Du Pont. 
O corante reativo predomina pela facilidade na produção; o sistema com corantes dispersos é outra possibilidade no mercado. Além disso, outro ponto limitante ainda é a velocidade de impressão.

O processo de estamparia digital têxtil está baseado na impressão a jato de tinta tipo Drop-On-Demand (DOD), no qual as gotas de tinta são expelidas por pequenos orifícios e direcionadas imediatamente para o substrato para formar a imagem. Existem diversos mecanismos diferentes; a forma mais comum utiliza o calor para vaporizar uma pequena quantidade de água e tinta em uma câmara para formar uma bolha de gás. Isso cria uma gota de tinta que é expelida de uma abertura na câmara.

Esta é preenchida outra vez antes que a próxima gota seja expelida. Outra variação deste tipo usa um cristal piezoelétrico, que pode ser levemente deformado pela passagem de uma corrente (através do cristal), a qual reduz o volume da câmara e causa a ejeção de uma gota de tinta.

Segundo os especialistas das seis indústrias têxteis entrevistadas, essa tecnologia elimina a necessidade de criar telas e rolos de estamparia, favorecendo uma maior flexibilidade e melhoria na eficiência do processo. Além disso, foi mencionada a vantagem de se customizar elementos de design e cores, atendendo às preferências individuais do consumidor.

Sua aparência após estampado é a de quadricromia. Suas cores são formadas pelos pixels em jatos de tinta e podem ser estampados praticamente todos os tipos de desenhos que se desejar, os de qualquer padronagem que conhecemos em estamparia e inclusive ou principalmente os formados por fotos e/ou ilustrações com todas as cores possíveis.

O mais recente desenvolvimento significativo na DuPont Artistri foi o lançamento da versão de grande formato, a 3320, com uma largura de impressão de $3.30 \mathrm{~m}$, e que trabalha com pigmentos e corantes. 
O interessante é que, com pigmentos, o ligante já está incorporado à tinta nos cartuchos de 2 litros das tintas Artistri série 700. O sucesso desta máquina está ligado ao mercado de cortinas e roupas de cama e mesa, e possui a mesma

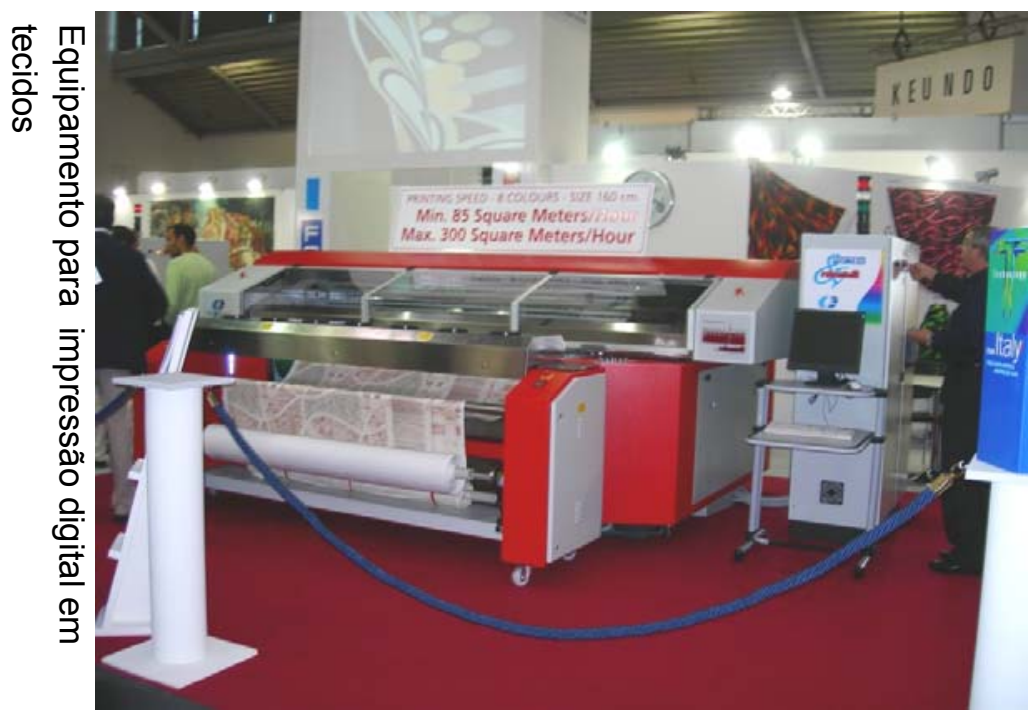
configuração da Artistri 2020 de $1.80 \mathrm{~m}$ de largura, com 16 cabeças de impressão, de acordo com o jornal ITMA (Daily New, 2007 sept).

A Robustelli apresentou na ITMA $^{1}$, 2007 em MuniqueAlemanha, um novo protótipo da Monna Lisa, que contém novas e "exclusivas" cabeças de impressão Epson Type-M e, de acordo com a For.tex, que supre as tintas Genesta para a máquina, características especiais possibilitam um ciclo de velocidade que surpreende. O novo protótipo foi desenhado para liberar bem mais que o dobro da velocidade de impressão do modelo original, com mais de $96 \mathrm{~m}^{2}$ por hora a uma resolução de 720 dpi, com versões disponíveis de $1.60 \mathrm{~m}, 1.80 \mathrm{~m}$ ou $3.20 \mathrm{~m}$.

\subsubsection{Processos de Gravação}

Para gravar um desenho num quadro ou cilindro, utilizam-se dois processos:

- Artesanal $\rightarrow$ com o uso de fotolitos manualmente.

- Digital $\rightarrow$ onde o desenho é gravado diretamente na tela.

Fases para gravação de quadros

O quadro é constituído de moldura e de uma gaze (nylon), ou tecido, que é esticada e fixada na moldura.

Originalmente os quadros eram esticados com seda, daí o nome de Seri (seda em latim) - Grafia, ou silk-screen (silk=seda; screen=tela). 
A estamparia de quadros utiliza telas de nylon em diferentes perfurações denominada de "Mesh". Existem vários tipos de meshes: 80 , 90, 100, 120 , para serem utilizados em cada tipos de desenhos.

Atualmente, utilizam-se tecidos de poliéster de alta precisão fabricados exclusivamente para este fim, devido a sua excelente estabilidade dimensional.

Os melhores tecidos de poliéster monofilamento são de procedência Suíça.

As molduras podem ser de: madeira, alumínio ou ferro, sendo que as melhores são de alumínio e ferro.

Formas de aplicação:
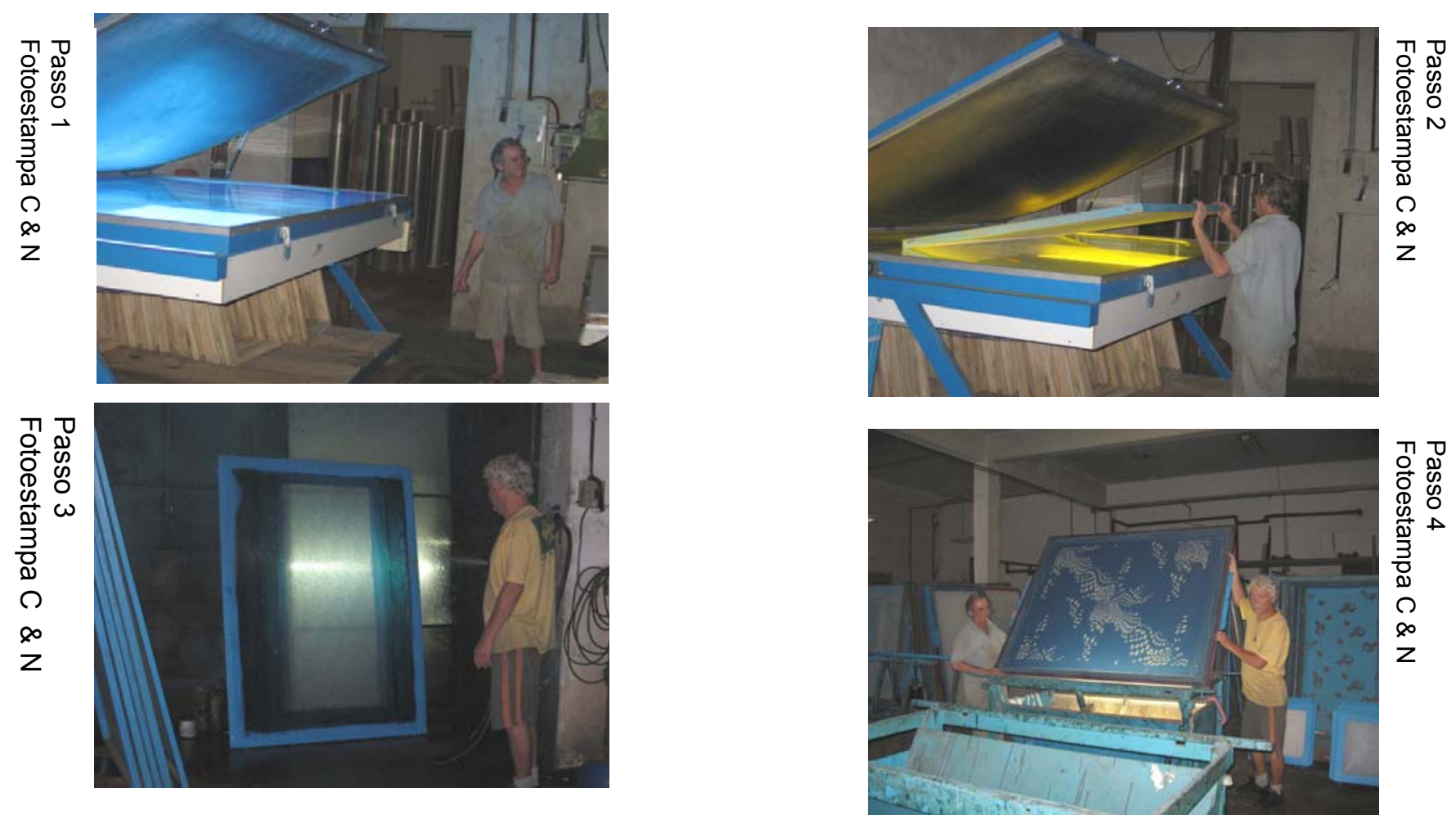

1- Para serem gravadas, é necessário aplicar uniformemente uma emulsão fotográfica com muita técnica, ao tecido do quadrado com um aplicador apropriado;

2- Após secagem na posição horizontal a tela pode ser gravada;

3- Prensa-se a arte final ou fotolito entre a tela e um vidro, e se expõe a uma fonte de luz por um tempo determinado; 
4- Após isto, com um jato de água, molha-se a tela. A área protegida pela arte que não recebeu luz, não endurece, deixando aberta a área por onde a tinta vai passar durante a impressão, reproduzindo exatamente o desenho original; O último passo é fixar com emulsão para conservar a tela.

Para cada cor significa um quadro ou cilindro, seu conjunto forma a sua totalidade. O desenhista separa as cores em fotolitos, denominados negativos.

\section{Fases para gravação de cilindro}

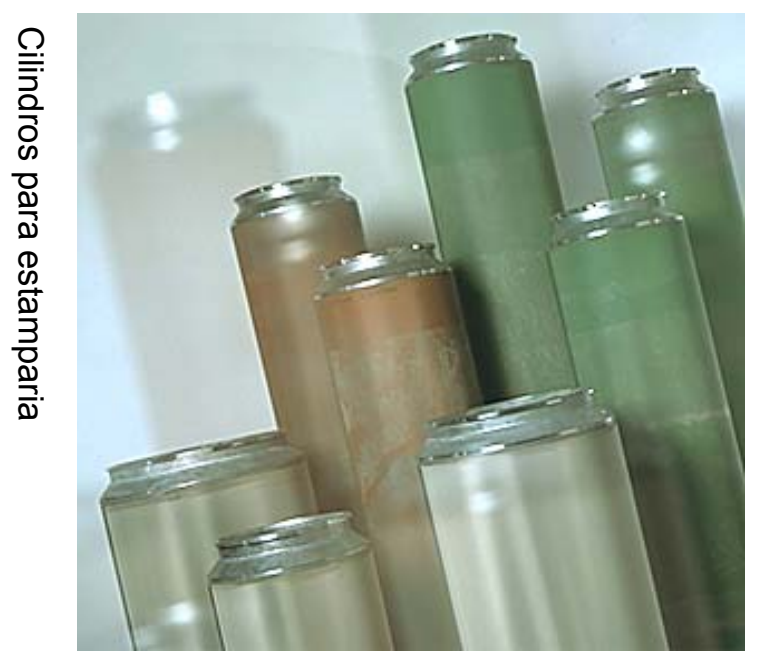

Cilindro é uma folha de tela metálica, que tem a propriedade de ser perfurada fotograficamente de acordo com o desenho a ser gravado e utiliza anéis de metal nas extremidades. Cada um dos cilindros corresponde a diferentes cores do desenho, formando as mais lindas e inúmeras padronagens que conhecemos.

Para se gravar um cilindro, o processo pode ser digital usando gravadoras a laser e cera ou artesanal utilizando fotolitos. Tipos de cilindro: Larguras do cilindro 1,50 m, $1,80 \mathrm{~m}$ e $2,20 \mathrm{~m}$.

A gravação dos cilindros é feita por fotossensibilização, e consiste basicamente nas seguintes operações:

- Aplicação de uma camada de resina à tela

- Secagem da resina

- Colocação do dispositivo sobre a tela

- Fotossensibilização propriamente dita, ou seja exposição da tela à luz

- Envernização da tela ou polimerização da resina.

- Colocação dos anéis laterais para cilindros de tela metálica. 

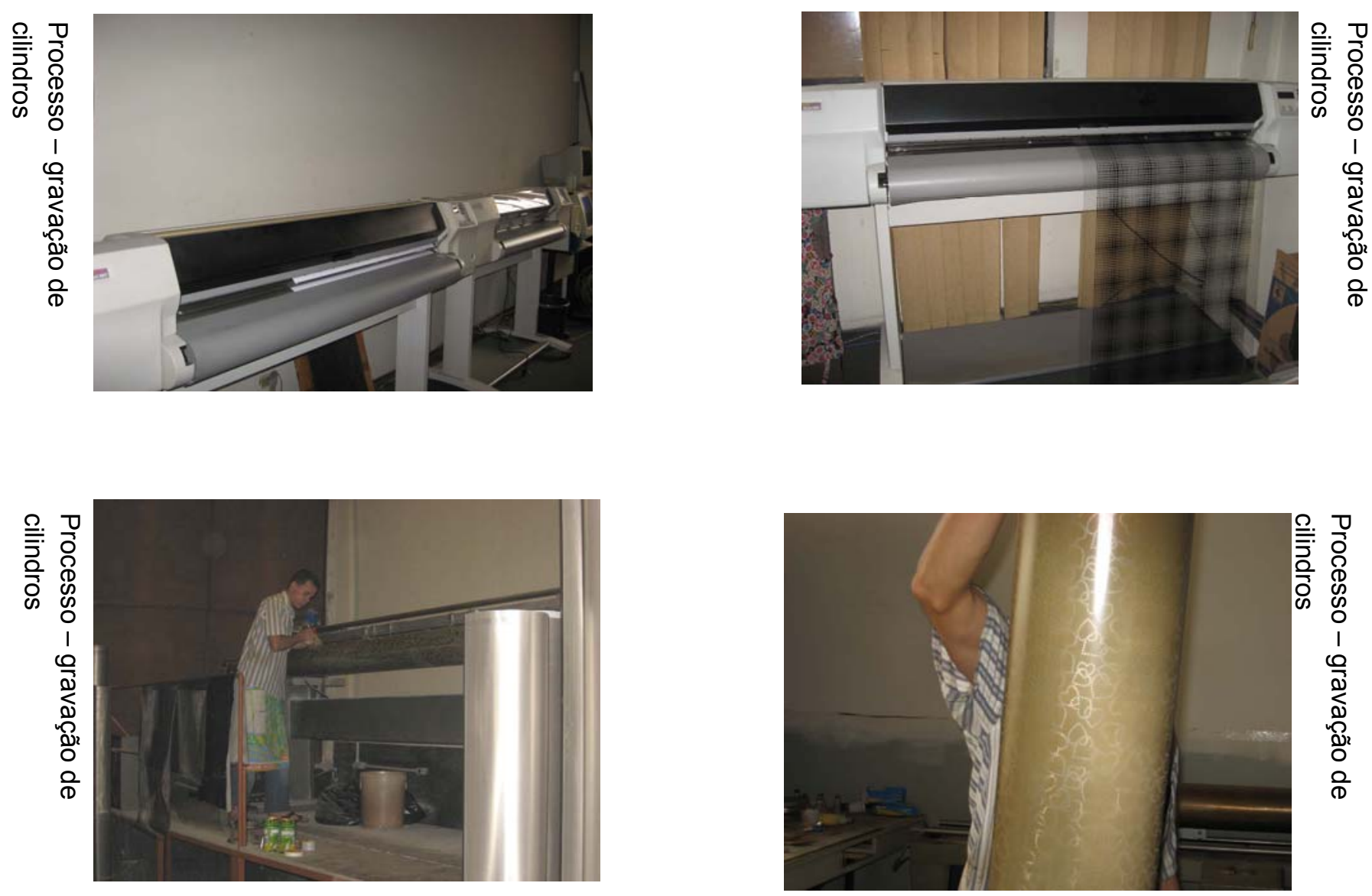

\footnotetext{
${ }^{1}$ A ITMA é a maior e a mais reconhecida feira internacional de máquinas para o setor têxtil, tornandose o principal ponto de encontro do mercado internacional ,apresentando seus mais recentes avanços e soluções.
} 


\section{CONCLUSÃO}

Mesmo vivendo num mundo globalizado, com informações sendo acessadas ao mesmo tempo em todos os lugares, a cultura preponderante de cada local contribui para a fixação da moda. As preferências por determinadas cores não são influenciadas pela moda, existindo uma realidade local que determina a escolha da estamparia do vestuário de acordo com o clima, música, cor da pele e ainda, como um fator único, a influência da mídia.

A estamparia evoluiu de forma gradativa no decorrer dos séculos, mas desde a industrialização não deixa de se atualizar constantemente, representando uma Arte na área Têxtil. Cabe então ao estilista buscar novas inspirações através de pesquisas dos movimentos artísticos, das culturas, dos povos indígenas, orientais, africanos etc.

Estamos numa era digital e informatizada, na qual agilidade e atualização são fatores chaves para atender às necessidades do consumidor e para alcançar o sucesso de uma empresa. Ao visualizar um desenho estampado em um tecido, dificilmente se notará se os traços foram criados pelo processo artesanal ou digital. O trabalho final, em ambos os casos, em termos de aspecto visual, é o mesmo.

Por fim, ressaltamos o fácil acesso a todas as fontes citadas, esclarecendo estarmos munidos dos devidos subsídios para aprofundar e aumentar os conhecimentos a respeito desta área tão abrangente e de uso da maioria dos seres humanos. Citada área se faz presente no dia-a-dia das diferentes culturas, recolhendo e sistematizando informações.

Toda a prática adquirida nestes anos é colocada nesta pesquisa técnico-científica, esperando proporcionar subsídios à atual geração de profissionais do ramo têxtil, bem como uma base sólida para as futuras gerações. 


\section{REFERÊNCIAS BIBLIOGRÁFICAS}

ANVIL GRAFIC DESIGN, Inc. Raccolta di Motivi e Tavola Dei Colori. Itália: il Castello Srl, 2005.

ARISTÓFANES. As Aves - As vespas - As rãs. Rio de Janeiro: Jorge Zahar, 2004.

BIRREN, Faber. A Grammar of Color - A Basic Treatise on the Color System of Albert H. Munsell. Nova Iorque: Reinhold Book Corporation, 1969.

BRAGA, João. História da Moda: Uma Narrativa. São Paulo: Editora Anhembi Morumbi, 2004.

BRAGA, João. Reflexões sobre Moda, Volume I. São Paulo: Editora Anhembi Morumbi, 2008.

BRUSATIN, Manlio. Historia de los Colores. Barcelona, 1987.

CALDAS, Dario. Observatório de sinais: Teoria e prática das tendências. Rio de Janeiro: Editora Senac , 2004.

CASTILHO, Kathia. Discursos da Moda: semiótica, Design e Corpo. São Paulo: Editora Anhembi Morumbi, 2005.

CORDOVIL, Joana dos Santos. Passarinhada: pássaro junino. Belém: Instituto de Artes do Pará, 2002.

COSGRAVE, Bronwyn. Historia de la Moda Desde Egipto Hasta Nuestros Dias. Barcelona: Editorial Gustavo Gili, 2005.

DE GRANDIS, Luigina. Teoria e Uso Del Colore. Milão: Mondadori, 2007.

FAUUSP. Sobre o Tema da Cor. 1975.

GARCIA, Clovis. O Aproveitamento do Folclore no Teatro Erudito in. Boletim de Leitura da Associação Brasileira de Folclore. São Paulo: Museu de Folclore Rossini Tavares de Lima $n^{0}$ 12, junho de 1994.

GOETHE, Johann Wolfgang von. Doutrina das Cores. São Paulo: Nova Alexandria, 1993.

GRANA, Cosetta.Tecnologia e Merceologia Tessile 1 - Per la formazione degli operatori Del settore tessile-abbigliamento. Itália: Editrice San Marco, 2005.

GUIDE DE LA GASTRONOMIE. Paris Gourmand. Paris: Office du Tourisme et dês Congrès de Paris, 2008

JOBIN, Gabriela; NEVES, M. in Design de Moda. Olhares Diversos. Pires, DB (org.) 
JONES, Sue Jenkyn. Fashion design: Manual do estilista. Tradução lara Biderman. São Paulo: Cosac Nalfy, 2005.

KORRIGAN. Moda: O que é; Como Acontece.

KUPPERS, Harald. Color - Origen, Metodología, Sistematización, Aplicatción. Espanha: Editorial Lectura, 1973.

LADCHUMANANANDASIVAM, Rasiah. Série Processos Químicos Têxteis, Volume II - Ciência da Cor. Natal, RN: UFRN, 2002

L'OFFICIEL 1000 MODÈLES - Accessoires Automne - Hiver 2007/2008. Edição $\mathrm{n}^{\circ} .75$, maio 2007.

MACNAMARA, Andréa. Design and Practice for Printed Textiles. Australia: Oxford University Press, 1995.

MALCOM BRIGDE. Best 100 Item - Volume 4 - 08/09 F/W Women's First Collection. MARCOLLINI, Attilio. Teoria Del Campo 2 - Corso di Metodologia della Visione. Florença, Itália: RCS Sansoni Editore S.p.A, 1989.

MATTAR, Fauze Najib. Gerência de Produtos: Como Tornar seu Produto um Sucesso. $2^{a}$ Edição. São Paulo: Atlas, 2003.

MEDEIROS, Maria de Jesus Farias. Docente: Faculdade Católica do Ceará-Marista artigo: Lino Villaventura: Criação de Moda Versus Arte na Elaboração do Design na Superfície Têxtil.

MILES, Leslie W.C. Textile Printing. Inglaterra: Society of Dyers and Colourists, 1994.

PEZZOLO, Dinah Bueno. Tecidos: História, Tramas, Tipos e Usos. São Paulo: Editora Senac São Paulo, 2007.

PIRES, Dorotéia Baduy (Vários autores). Design de Moda: Olhares Diversos. Barueri, SP: Estação das Letras e Cores Editora, 2008.

REFKALEFSKY, Margaret. Pássaros... bordando sonhos: função dramática do figurino no teatro dos pássaros de Belém do Pará. Belém: IAP, 2001.

SILVA, Dilma de Melo. Arte Africana e Afro-Brasileira. São Paulo: Terceira Margem, 2006.

TASCHEN, Benedikt. Piet Mondrian - Construção Sobre o Vazio. Alemanha: Benedikt Taschen Verlag GmbH, 1995.

TEIXEIRA, Francisco. A História da Indústria Têxtil Paulista. São Paulo: Artemeios, 2007. 
VILLAVENTURA, Lino. Coleção Moda Brasileira. São Paulo: Cosac Naify, 2007. www.moda.terra.com.brl.../0,,Ol845010-El6124,00.html 


\section{Desenvolvimento de Produto}

1-DEFINIÇAO COLEÇÃO .............................. FINAL /MAIO

2- CARTELA CORES / TECELAGEM ...........................JUNHO

3- TECELAGEM................................... JULHO/AG/SET.

4- TINTURARIA / ESTAMPARIA............ OUT/NOV/DEZ.

5- CONF.MOSTRUÁRIO

.JAN / FEV

6- LANÇAMENTO VERÃO FEV / MARÇO

7- LANÇAMENTO TEC. ALTO VERAO ............................MAIO/ JUNHO

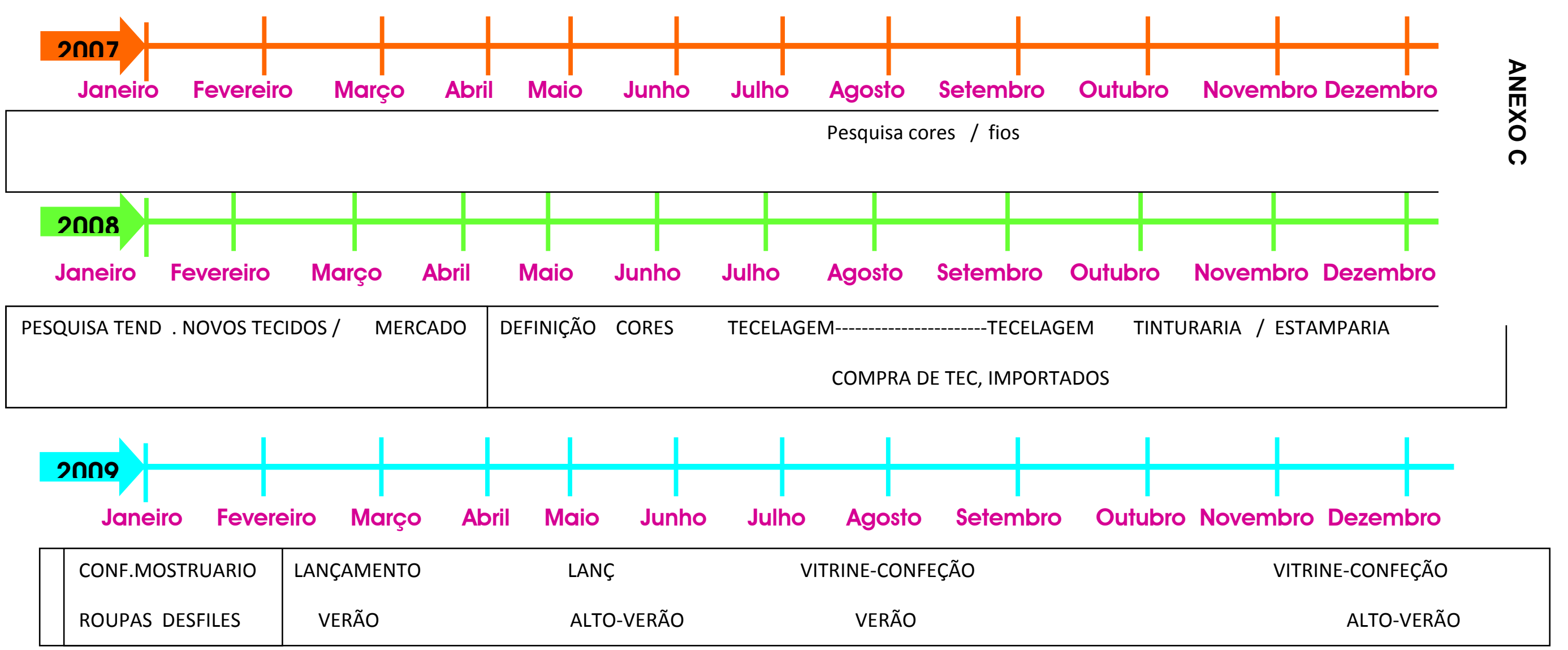




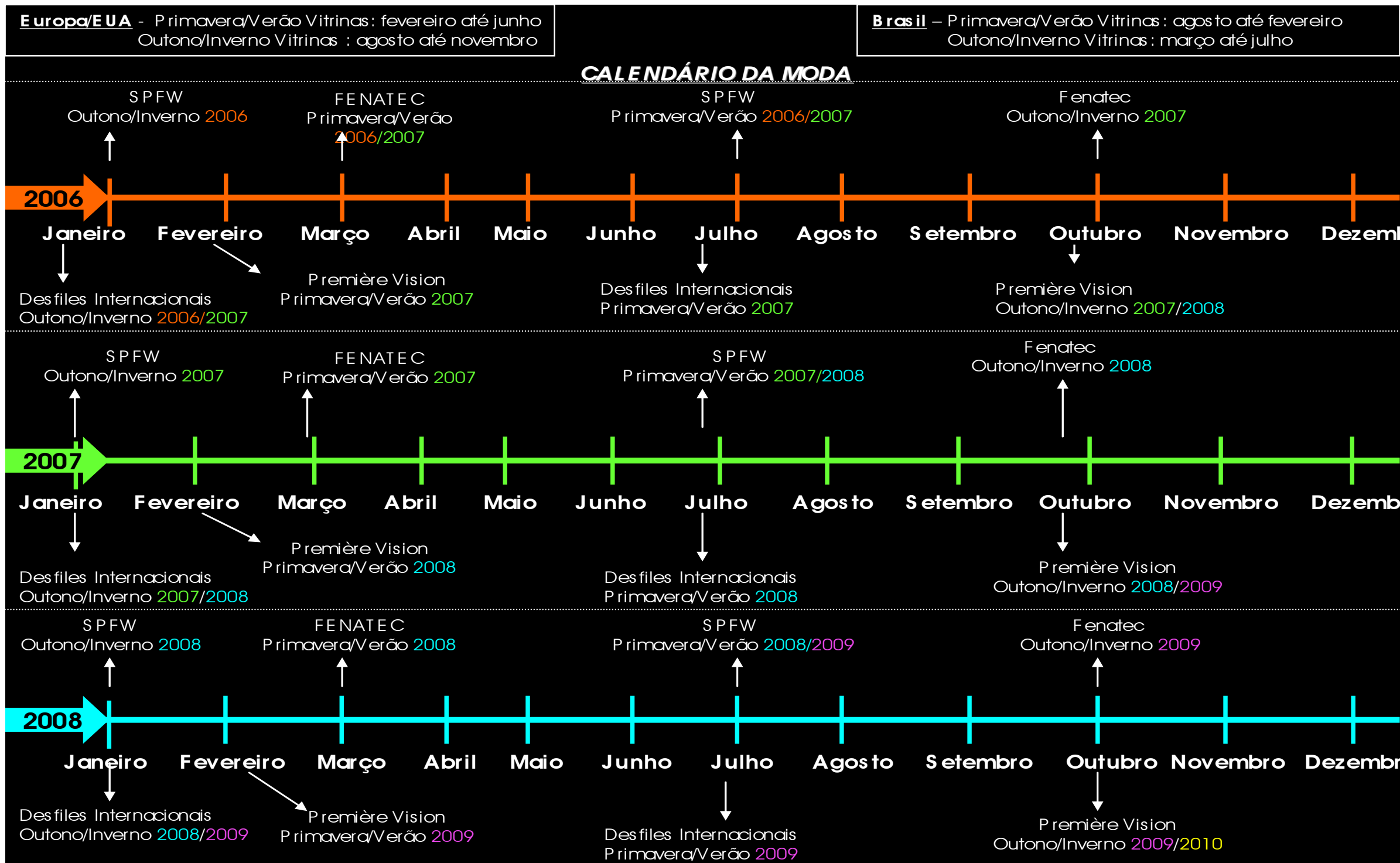

